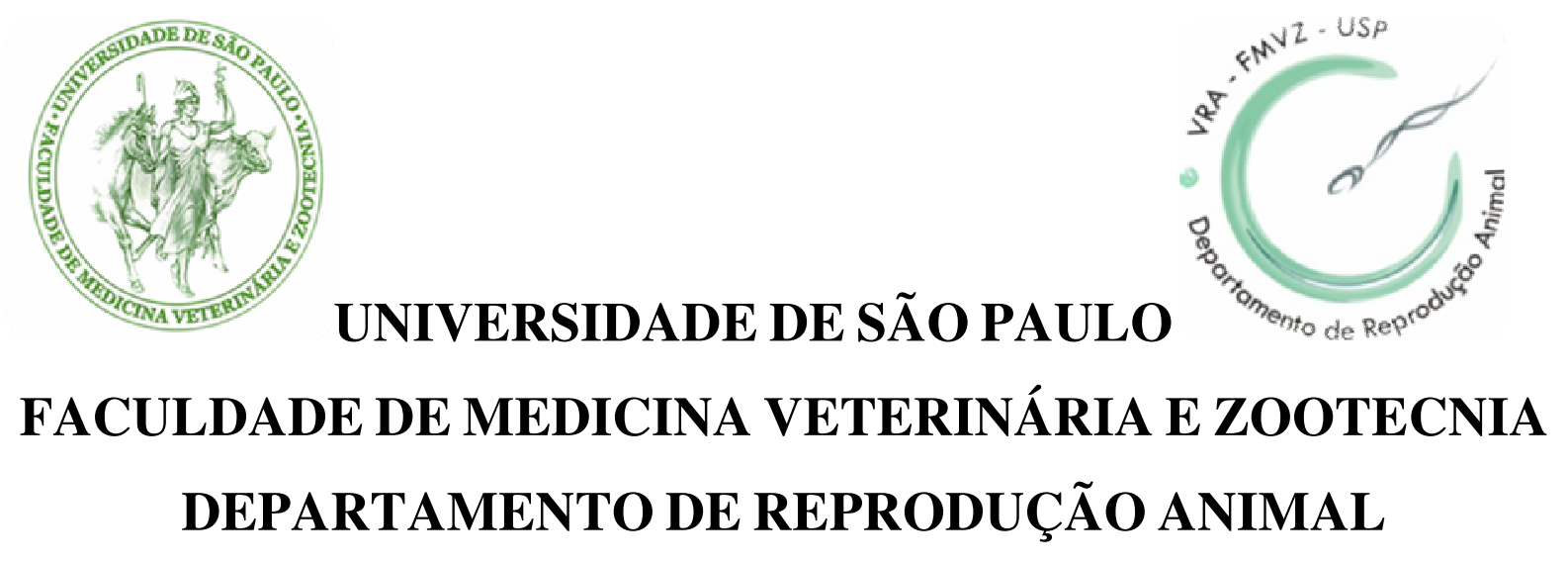

\title{
EFEITO dO SELÊNIO ORGÂNICO NAS \\ CARACTERÍSTICAS DO SÊMEN IN NATURA E REFRIGERADO DE CACHAÇOS
}

Simone MARIA MASSAMI KitAMURA MARTINS 


\section{SIMONE MARIA MASSAMI KITAMURA MARTINS}

\section{Efeito do selênio orgânico nas características do sêmen in natura e refrigerado de cachaços}

Tese apresentada ao Programa de PósGraduação em Reprodução Animal da Faculdade de Medicina Veterinária e Zootecnia da Universidade de São Paulo como parte integrante dos requisitos para a obtenção do título de Doutor em Ciências

Departamento:

Reprodução Animal

Área de Concentração:

Reprodução Animal

Orientador:

Prof. Dr. Rubens Paes de Arruda

São Paulo 
Autorizo a reprodução parcial ou total desta obra, para fins acadêmicos, desde que citada a fonte.

\section{DADOS INTERNACIONAIS DE CATALOGAÇÃO-NA-PUBLICAÇÃO}

(Biblioteca Virginie Buff D’Ápice da Faculdade de Medicina Veterinária e Zootecnia da Universidade de São Paulo)

\section{Martins, Simone Maria Massami Kitamura}

Efeito do selênio orgânico nas características do sêmen in natura e refrigerado de cachaços / Simone Maria Massami Kitamura Martins. -- 2011. $126 \mathrm{f}$ : : il.

Tese (Doutorado) - Universidade de São Paulo. Faculdade de Medicina Veterinária e Zootecnia. Departamento de Reprodução Animal, São Paulo, 2011.

Programa de Pós-Graduação: Reprodução Animal.

Área de concentração: Reprodução Animal.

Orientador: Prof. Dr. Rubens Paes de Arruda.

1. Suíno. 2. Sêmen. 3. Selênio orgânico. 4. PHGPx. 5. Características espermáticas. 1. Título. 


\section{CERTIFICADO}

Certificamos que o Projeto intitulado "Efeito da biodisponibilidade do selênio orgânico nas características do sêmen in natura e diluído de cachaços", protocolado sob o $\mathrm{n}^{0} 1426 / 2008$, utilizando 14 (catorze) suínos, sob a responsabilidade do Prof. Dr. Rubens Paes de Arruda, está de acordo com os princípios éticos de experimentação animal da Comissão de Bioética da Faculdade de Medicina Veterinária e Zootecnia da Universidade de São Paulo e foi aprovado "ad referendum".

We certify that the Research "Effect of bioavailability of organic selenium on boar semen characteristics in natura and diluted", utilizing 14 (fourteen) swine, protocol number 1426/2008, under the responsibility Prof. Dr. Rubens Paes de Arruda, agree with Ethical Principles in Animal Research adopted by Bioethic Commission of the School of Veterinary Medicine and Animal Science of University of São Paulo and was approved "ad referendum" of the meeting.

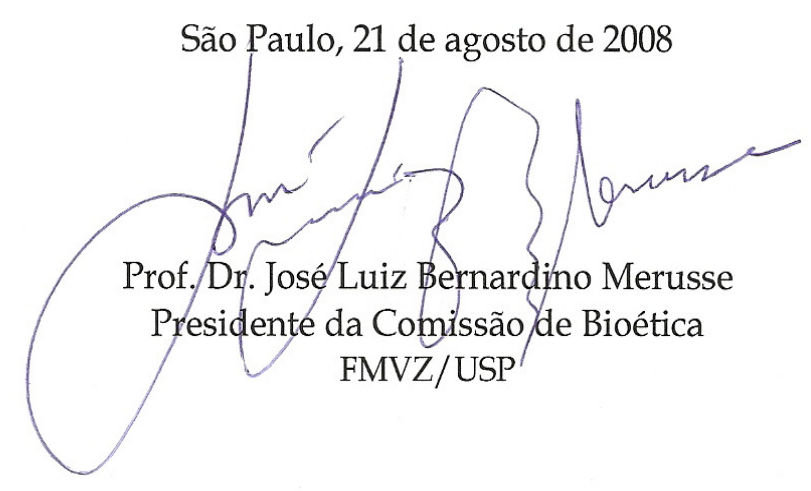




\section{FOLHA DE AVALIAÇÃO}

Nome: Simone Maria Massami Kitamura Martins

Título: Efeito do Selênio Orgânico nas Características do Sêmen in natura e Refrigerado de Cachaços

Tese apresentada ao Programa de PósGraduação em Reprodução Animal da Faculdade de Medicina Veterinária e Zootecnia da Universidade de São Paulo como parte integrante dos requisitos para a obtenção do título de Doutor em Ciências

Data:

Banca Examinadora

Prof. Dr.

Instituição:

Assinatura:

Julgamento:

Prof. Dr.

Instituição:

Assinatura:

Julgamento:

Prof. Dr.

Instituição:

Assinatura:

Julgamento:

Prof. Dr.

Instituição:

Assinatura:

Julgamento:

Prof. Dr.

Instituição:

Assinatura:

Julgamento: 
Dedico esta Tese,

Ao meu Pai (Antônio) que talvez mesmo sem saber me ensinou uma lição muita valiosa, nunca desista dos seus sonhos ... e se cheguei até o Doutorado foi graças a ele estar sempre ao meu lado, mesmo separados pela distância, porém sempre em suas orações.

Tenho muito a agradecer pelo seu apoio, sua preocupação, e por se esforçar para entender as minhas escolhas, mesmo as vezes não compreendendo.

$\mathcal{A}$ minha Mãe (Cecília in memorian) que sempre esteve e sempre estará ao meu lado me ajudando, principalmente nos momentos mais difíceis.

As minhas irmãs (Mônica, Alexandra e Renata) por apoiar as minhas decisões, mesmo não concordando com algumas delas.

As minhas tias Cida e Glória (in memorian) que sempre rezaram para eu encontrar o meu caminho e especialmente a tia Cida que me dizia "se as coisas não estão acontecendo do jeito que você espera, tenha paciência que se for para ser seu, será e ninguém poderá interferir, mas caso você se arrependa das suas escolhas, eu sempre estarei lá a sua espera”.

Não há um dia que eu não pense e reze por vocês

Amo muito vocês 
Ao Professor Rubens,

Tenho muito a agradecer, pois se fiz o Doutorado devo ao voto de confiança que depositaste em mim, ao me aceitar para ser sua orientada.

Quando cheguei ao seu Laboratório, não tinha muita experiêncía em manipular os equipamentos, em realizar algumas análises e o Senfor fez questão de me ensinar e garantir que eu realmente tivesse aprendido, pois o Senhor não se preocupa apenas em ensinar, mas em formar profissionais e o mais importante profissionais diferenciados.

Durante o meu doutorado pude ter um contato mais próximo e perceber o ser humano de bom coração que o Senhor é, que na medida do possivel tenta ajudar todos os seus orientados em assuntos que muitas vezes extrapolam o ambiente acadêmico.

Se aprendi com meu Pai a não desistir, o Senhor reforçou ainda mais essa perseverança. Me lembro quando cheguei até a sua sala e the disse que não estávamos conseguindo reproduzir as técnicas descritas em vários trabalhos sobre a $\mathcal{P H G P x}$ e o Senhor me contou a história da pedra no caminho "as vezes as pedras que aparecem no seu caminho são pequenas e você com apenas um salto consegue ultrapassá-la, mas as vezes as pedras são médias e apenas um ligeiro desvio você consegue chegar ao seu destino, porém as vezes... as pedras podem ser enormes e você terá que percorrer um longo trajeto para conseguir passar por este obstáculo".

Gostaria de agradecer todos os ensinamentos, todas as conversas nos momentos oportunos e por ter acerditado na proposta do selênio. 
Ao Professor Aníbal,

Gostaria de agradecer a confiança e todos os ensinamentos passados em todos esses anos de convivio. Agradecer pelas inúmeras oportunidades que não só me fizeram crescer profissionalmente, mas também como ser humano.

Acredito que o Senhor não apareceu em minha vida por acaso, nos conhecemos em um momento dificil para mim, mas o Senhor abriu as portas do Laboratório no meu estágio curricular e estou aqui até hoje, virei uma "suinóloga" como o Senhor mesmo gosta de denominar.

Tenho muito carinho pelo Senhor e por toda a sua familia que sempre me receberam muito bem. 


\section{Ao André "Simprão",}

Gostaria de agradecer toda a paciência, e olha que é necessária uma baita paciência, principalmente com meu peculiar mau humor logo cedo.

Existem tantos outros motivos que eu preciso agradecer... acho que não caberiam todos eles neste pequeno espaço. Mas, o principal deles é o seu amor e a sua dedicação comigo e com nosso "menino"

Todos os dias eu rezo e agradeço a Deus por ter te colocado na minha vida, pois tenho a certeza de que me tornei uma pessoa melhor ao seu lado.

Você entrou na minha vida de uma forma inesperada se tornou meu porto seguro, é a pessoa que eu posso contar em todas as situações possíveis e inimagináveis. $\mathcal{E}$ a mão que me afaga quando preciso de carinho, é a voz que me dá Gronca quando penso em parar, é o bom senso quando quero jogar tudo para o alto e é a sabedoria quando preciso me aconselhar...

Te amo muito... 
Agradecimentos

À Deus, por me permitir chegar até aqui e colocar pessoas tão especiais no meu caminho.

À Fundação de Amparo a Pesquísa do Estado de São Paulo $(\mathcal{F A P E S P})$ pelo financiamento desta pesquisa.

Ao Departamento de Reprodução Animal pela oportunidade de fazer parte desta benemérita instituição.

Aos Professores do Departamento de Reprodução Animal com quem pude além de conviver, granjear conhecimentos que foram e serão importantes em toda a minha vida profissional... Prof. Dr. Pietro Sampaio Baruselli, Prof. Dr. Marcelo Alcindo de Barros Vaz Guimarães, Prof. Dr. José Antonio Visintin, Profa. Dra. Valquiria Hyppolito Barnabe, Prof. Dr. Renato Campanarut Barnabe, Profa. Dra. Clair Motos de Oliveira, Profa. Dra. Camila Infantosi Vannucchi, Profa. Dra. Mayra Elena Ortiz D'Avila Assumpção, Prof. Dr. Claudio Alvarenga de Oliveira, Profa. Dra. Eneiva Carla Carvalho Celeghini e a Profa. Dra. Claudia Barbosa Fernandes.... muito obrígado!

Aos Professores do CBRA, $\mathcal{D}$. Mário Binelli, Dr. $\mathcal{E} d$ Madureira, Dra. Annelise de Souza Traldi pela convivência, pelos queijos e principalmente pelo meu conhecimento adquirido.

À amiga Carlinha por todos os ensinamentos, pela prazerosa convivência e principalmente pela amizade. 
Romy, e aos estagiários $\mathcal{N a t a n a , ~ P a u l o ~ " P a t r i m o ̂ n i o " ~ e ~ a o ~ M a r c o s ~ q u e ~ m e ~}$ acolheram com tanto carinho e sofreram junto comigo até a obtenção dos resultados. Serei eternamente a "agregada" do Laboratório.

Aos funcionários Fabinho e Cris tanto pela amizade e carinho que tenho por eles, como pela dedicação e qualidade dos serviços prestados aos animais que tanto gosto.

Aos funcionários Márcio de Carli, João Carlos Pinto e José Maria Bernardi, pela amizade e também pelos auxílios para a realização deste trabalho.

Ao secretárío do CBRA Clayton pela disposição, dedicação e presteza em realizar seus serviços.

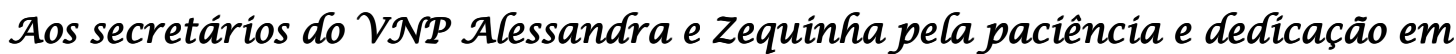
atender e a Maria, Cida, Suelen e Cecilia.

À Harumi $\mathcal{D}$. Shiraishi, pela dedicação e presteza de sempre.

À Elza Faquim, pela agilidade e qualidade e, principalmente por privar seus momentos de lazer em detrimento a ajudar-nos.

À Vet Life Produtos Veterinários, por ceder seus produtos, sem restrições, em todos os momentos que necessitamos.

À Alltech Inc. por ceder seu produto.

À Agroceres $\mathcal{N}$ utrição Animal por formularem a dieta, especialmente para $o$ desenvolvimento deste estudo. 
Enfim, gostaria de agradecer às muitas pessoas que me ajudaram na realização desta etapa da minha vida acadêmica. Para chegar à data de hoje, dia de minha defesa, com os resultados em mãos, ou melhor, dizendo impressos, tive inúmeras colaborações.

Sei que nem tudo sai perfeito, mas trabalhamos para chegar o mais perto disso e agradeço de coração a todos que abraçaram a minha idéia e me ajudaram a torná-la real.

Acredito que de todas as etapas que passei para a realização deste trabalho, a mais árdua foi reproduzir a metodología para a determinação da atividade da enzima PHGPX. Essa sem dúvida nenhuma foi a mais trabalhosa e a que exigiu mais persistência, dedicação e paciência de minha parte, do meu orientador, da Professora Mariza e da Silvana que estiveram comigo nessa empreitada.

Obrigada por não desistirem.

"Life will knock us down...but we can choose whether or not to get back up" 


\section{RESUMO}

MARTINS, S.M.M.K. Efeito do selênio orgânico nas características do sêmen in natura e refrigerado de cachaços [Effect of organic selenium on raw and stored semen characteristics in boars] 2011. 126 f. Tese de Doutorado apresentada ao Programa de Pós-Graduação em Reprodução Animal (Doutorado em Ciências) - Faculdade de Medicina Veterinária e Zootecnia, Universidade de São Paulo, São Paulo, 2011.

O selênio exerce função marcante na qualidade do sêmen, atuando no desenvolvimento da peça intermediária, no desenvolvimento das células de Sertoli, e, como componente das selenoproteínas, principalmente a glutationa peroxidase. O selênio é utilizado comumente nas dietas animais como selenito de sódio (inorgânica) e as fontes orgânicas têm revelado diferenciada biodiponibilidade, sendo importantes para aumentar o aproveitamento pelos animais e reduzir o impacto ambiental. Assim, o experimento averiguou os efeitos do selênio orgânico nas características seminais no sêmen in natura e refrigerado a $18^{\circ} \mathrm{C}$ por três dias. Foram utilizados 12 cachaços divididos em três tratamentos: CoNTROLE - dieta formulada utilizando fonte inorgânica $(0,30 \mathrm{ppm}$ de selenito de sódio, $\mathrm{n}=4)$, INORGÂNICO - dieta formulada utilizando fonte inorgânica $(0,50 \mathrm{ppm}$ de selenito de sódio, $\mathrm{n}=4)$ e ORGÂNICO dieta formulada utilizando fonte orgânica $\left(0,50\right.$ ppm de selênio- Sel-Plex ${ }^{\mathrm{TM}}$, Alltech, Inc., $\mathrm{n}=4$ ). As análises do sêmen consistiram da avaliação computadorizada da motilidade (CASA), e análises por citometria de fluxo da integridade das membranas plasmática e acrossomal, potencial de membrana mitocondrial, peroxidação lipídica, atividade da fosfolipídio hidroperóxido glutationa peroxidase. Associado a estas análises avaliou-se a concentração de selênio no plasma sangüíneo e seminal. Os dados foram submetidos à análise de variância, empregando-se o programa SAS (1999). As hipóteses testadas foram consideradas significativas quando $\mathrm{p}<0,05$. Na análise do sêmen in natura constatou-se que a concentração espermática, o número total de células e o número de doses foram influenciados positivamente pelo tratamento orgânico, assim como os percentuais de células normais. Os percentuais de defeitos de cabeça, peça intermediária e gota proximal foram menores nos animais suplementados com selênio levedura, contudo os defeitos de cauda do espermatozóide foram mais elevados. O defeito de colo do espermatozóide também foi reduzido pela suplementação de selênio. Porém, as integridades de membranas acrossomal e plasmática, potencial mitocondrial e peroxidação das membranas espermáticas, bem como as características de motilidade não melhoraram com a utilização de selênio levedura. A concentração de selênio no plasma sangüíneo e seminal foram maiores no grupo orgânico em 
comparação aos demais, assim como a atividade da enzima PHGPx. Em relação ao sêmen refrigerado averiguou-se que as integridades de membranas acrossomal e plasmática, potencial de membrana mitocondrial e peroxidação de membrana não foram influenciadas pela suplementação com selênio orgânico. Em contrapartida, as características de motilidade apresentaram diferenças significativas favoráveis ao tratamento orgânico, bem como o percentual de células normais e os defeitos de cabeça e gota proximal. O grupo orgânico apresentou maior percentual de defeitos de cauda comparativamente aos demais e a suplementação de selênio, independente da fonte reduziu os percentuais de defeitos de peça intermediária. A atividade da enzima PHGPx também foi influenciada positivamente pelo tratamento orgânico. Baseado nos resultados, efeitos positivos da suplementação de selênio orgânico $(0,50 \mathrm{ppm})$ na dieta foram observados em algumas características espermáticas no sêmen in natura e refrigerado de cachaços.

Palavras-chave: Suíno. Sêmen. Selênio orgânico. PHGPx. Características espermáticas. 


\begin{abstract}
MARTINS, S.M.M.K. Effect of organic selenium on raw and stored semen characteristics in boars [Efeito do selênio orgânico nas características do sêmen in natura e refrigerado de cachaços] 2011. 126 f. Tese de Doutorado apresentada ao Programa de PósGraduação em Reprodução Animal (Doutorado em Ciências) - Faculdade de Medicina Veterinária e Zootecnia, Universidade de São Paulo, São Paulo, 2011.
\end{abstract}

The selenium plays a remarkable role on semen quality by acting in the development of middle piece, in the development of Sertoli cells and also as a component of selenoproteins, primarily of glutathione peroxidase. The selenium is usually utilized on animal diets as sodium selenite (inorganic). Organic sources have revealed a differentiated bioavailability, becoming important allies to enhance its use by the animals and reducing environmental impact. Therefore, this experiment evaluated the effects of organic selenium on seminal characteristics on raw and stored semen at $18^{\circ} \mathrm{C}$ for three days. Twelve boars were divided into three experimental groups: CONTROL - inorganic sourced diet $(0.30 \mathrm{ppm}$ sodium selenite, $\mathrm{n}=4)$, INORGANIC - inorganic sourced diet $(0.50 \mathrm{ppm}$ sodium selenite, $\mathrm{n}=4)$ and ORGANIC organic sourced diet $\left(0.50 \mathrm{ppm}\right.$ selenium- Sel-Plex ${ }^{\mathrm{TM}}$, Alltech, Inc., $\left.\mathrm{n}=4\right)$. Semen analysis consisted of computerized assessment of motility (CASA) and flow cytometric analysis of plasmatic and acrosomal membranes integrity, mitochondrial membrane potential, lipidic peroxidation and phospholipid hidroperoxide glutatione peroxidase activity. Moreover, the blood and seminal plasma concentrations of selenium were evaluated. Data was submitted analysis of variance (SAS, 1999). Hypothesis tested were considered significant when $\mathrm{p}<0.05$. In natura semen analysis showed that spermatic concentration, total cell number, number of doses and percentage of normal cells were positively influenced by organic treatment. Percentages of head and middle piece defects and proximal cytoplasmic droplets were decreased on animals supplemented with yeast selenium; however percentages of tail defects were increased in these animals. Neck defects were reduced by selenium supplementation. Acrosomal and plasmatic membrane integrity, mitochondrial membrane potential and spermatic membrane peroxidation, as well as motility characteristics were not enhanced with the use of yeast selenium. Selenium concentration on blood and seminal plasma were higher on organic group, similarly to PHGPx activity. Stored semen analysis showed that acrosomal and plasmatic membranes integrity, mitochondrial membrane potential and membrane peroxidation were not influenced by organic selenium supplementation. Nonetheless, motility characteristics were maintained normal with significant differences on behalf of organic 
treatment, likewise the percentage of normal cells, head defects and proximal droplets. The organic group presented higher percentage of tail defects when compared to the others and supplementation with selenium, independently from the source, reduced the percentages of middle piece defects. PHGPx activity was also positively influenced by organic treatment. Based on results, positives effects of dietary organic selenium supplementation ( $0.5 \mathrm{ppm})$ were observed on some spermatic characteristics of raw and stored boar semen.

Key words: Swine. Semen. Organic Selenium. PHGPx. Sperm characteristics. 


\section{LISTA DE FIGURAS}

Figura 1 - Metabolismo, armazenamento, excreção e utilização do selênio nas espécies monogástricas

Figura 2 - Alojamento dos cachaços no Laboratório de Pesquisa em Suínos 45

Figura 3 - Laboratório de Biotecnologia do Sêmen e Andrologia ..... 46

Figura 4 - Fórmula utilizada para a distribuição dos cachaços nos tratamentos .46

Figura 5 - Esquema experimental de coleta de amostras para avaliação das características seminais e da biodisponibilidade do selênio.

Figura 6 - Esquema experimental das análises das amostras 50

Figura 7 - A: Higienização do prepúcio, B: Coleta de sêmen e C: Método da mão enluvada 51

Figura 8 - HTM-IVOS, Versão 12.3, Hamilton Thorn Research, Beverly, Massachussetts, USA. 53

Figura 9 - Microscópio de Contraste de Interferência Diferencial (DIC) .55

Figura 10 - Espectrofotômetro Beckman DU 800 .58

Figura 11 - Coleta de sangue por punção da veia jugular 59 


\section{LISTA DE TABELAS}

Tabela 1 - Composição das dietas fornecida aos cachaços dos tratamentos (Continua).

Tabela 2 - Médias e desvios-padrão das características do sêmen in natura de cachaços durante 77 dias

Tabela 3 - Médias \pm desvios-padrão das características do sêmen in natura de cachaços em intervalos de 14 dias

Tabela 4 - Médias e desvios-padrão de integridade da membrana plasmática e acrossomal, potencial mitocondrial e peroxidação de membrana no sêmen in natura de cachaços durante 77 dias

Tabela 5 - Médias \pm desvios-padrão das características de integridade da membrana plasmática e acrossomal, potencial mitocondrial e peroxidação lipídica de membrana no sêmen in natura de cachaços em intervalos de 14 dias

Tabela 6 - Médias e desvios-padrão das características de motilidade no sêmen in natura de cachaços durante 77 dias (Continua)

Tabela 7 - Médias \pm desvios-padrão das características de motilidade no sêmen in natura de cachaços em intervalos de 14 dias (Continua).

Tabela 8 - Médias e desvios-padrão das anormalidades morfológicas no sêmen in natura de cachaços durante 77 dias

Tabela 9 - Médias \pm desvios-padrão de anormalidades morfológicas no sêmen in natura de cachaços em intervalos de 14 dias (Continua).

Tabela 10 - Médias e desvios-padrão da atividade da enzima PHGPx no sêmen in natura de cachaços durante 77 dias.

Tabela 11 - Médias \pm desvios-padrão da atividade da enzima PHGPx (mU/mg de proteína) no sêmen in natura de cachaços em intervalos de 14 dias

Tabela 12 - Médias e desvios-padrão da concentração de selênio durante 77 dias..... 
Tabela 13 - Médias \pm desvios-padrão da concentração de selênio em ng/mL em intervalos de 14 dias

Tabela 14 - Médias e desvios-padrão de integridade da membrana plasmática e acrossomal, potencial mitocondrial e peroxidação de membrana no sêmen refrigerado de cachaços durante 72 horas.

Tabela 15 - Médias \pm desvios-padrão das características de integridade da membrana plasmática e acrossomal, potencial mitocondrial e peroxidação de membrana no sêmen refrigerado de cachaços em intervalos de 24 horas .....

Tabela 16 - Médias e desvios-padrão das características da motilidade no sêmen refrigerado de cachaços durante 72 horas.

Tabela 17 - Médias \pm desvios-padrão das características de motilidade no sêmen refrigerado de cachaços em intervalos de 24 horas (Continua)..... .88

Tabela 18 - Médias e desvio-padrão das anormalidades morfológicas no sêmen refrigerado de cachaços suplementados com selênio durante 72 horas

Tabela 19 - Médias \pm desvios-padrão de anormalidades morfológicas no sêmen refrigerado de cachaços durante 24 horas

Tabela 20 - Médias e desvios-padrão da atividade da enzima PHGPx no sêmen refrigerado de cachaços durante 72 horas

Tabela 21 - Médias \pm desvios-padrão da atividade da enzima PHGPx (mU/mg de proteína) nos espermatozóides do sêmen refrigerado de cachaços em intervalos de 24 horas 


\section{LISTA DE ABREVIATURAS E SIGLAS}

\begin{tabular}{|c|c|}
\hline$\mu \mathrm{L}$ & Microlitro \\
\hline$\mu \mathrm{m}$ & Micrômetro \\
\hline$\mu \mathrm{M}$ & Micromolar \\
\hline AIMI & Espermatozóides viáveis com a membrana acrossomal íntegra \\
\hline ALH & Amplitude lateral da cabeça \\
\hline ATP & Adenosina trifosfato \\
\hline $\mathrm{BCF}$ & Freqüência de batimento \\
\hline C11-BODIPY ${ }^{581 / 591}$ & $\begin{array}{l}\text { 4,4-difluoro-5-(4-phenyl-1,3-butadienyl)-4-bora-3 }{ }^{\mathrm{a}}, 4^{\mathrm{a}} \text {-diaza-s-indacene- } \\
\text { 3-undecanoic acid }\end{array}$ \\
\hline CASA & $\begin{array}{l}\text { Computer Assisted Semen Analisys (Análise Computadorizada do } \\
\text { Sêmen) }\end{array}$ \\
\hline EROs & Espécies reativas de oxigênio \\
\hline FITC & Isotiocianato de fluoresceína \\
\hline $\mathrm{g}$ & Grama \\
\hline$g$ & Gravidade \\
\hline GLM & General Linear Models \\
\hline GPx & Glutationa peroxidase \\
\hline GR & Glutationa redutase \\
\hline GSH & Glutationa reduzida \\
\hline $\mathrm{H}_{2} \mathrm{O}_{2}$ & Peróxido de hidrogênio \\
\hline $\mathrm{Hz}$ & Hertz \\
\hline IA & Inseminação artificial \\
\hline IFMI & $\begin{array}{l}\text { Intensidade da fluorescência da população espermática com membrana } \\
\text { plasmática íntegra e coradas com a sonda fluorescente C11- } \\
\text { BODIPY }\end{array}$ \\
\hline IP & Iodeto de propídio \\
\hline $\mathrm{JC}-1$ & $\begin{array}{l}\text { Iodeto de 5,5',6,6'-tetracloro-1,1',3,3'- } \\
\text { tetraetilbenzimidazolilcarbocianina }\end{array}$ \\
\hline $\mathrm{kDa}$ & Quilodalton \\
\hline $\mathrm{Kg}$ & Quilograma \\
\hline LIN & Linearidade \\
\hline
\end{tabular}


M

MAI

mg

MI

$\min$

$\mathrm{m}^{2}$

$\mathrm{mL}$

$\mathrm{mM}$

MP

MP

MPI

MPL

MT

$\mathrm{mU}$

$\mathrm{NADPH}$

$\mathrm{Na}_{2} \mathrm{SeO}_{3}$

$\mathrm{Na}_{2} \mathrm{SeO}_{4}$

$\mathrm{nm}$

ng

$\mathrm{O}_{2}^{-\bullet}$

$\mathrm{OH}^{-}$

$\mathrm{p}$

ppm

$\mathrm{PC}-\mathrm{OOH}$

PHGPx

PSA

S

SAS

$\mathrm{Se}$

SeCis

SeMet

SOD

STR

TALP
Molar

Somatória das células com membrana acrossomal íntegra

Miligrama

Somatória das células com membrana plasmática íntegra

Minuto

Metro quadrado

Mililitro

Milimolar

Espermatozóide com médio potencial de membrana mitocondrial

Motilidade progressiva

Células com membrana plasmática íntegra (viáveis)

Espermatozóide com membrana plasmática lesada

Motilidade total

miliunidades

Nicotinamida Adenina Di-nucleotídio Fosfato

Selenito de sódio

Selenato de sódio

Nanômetro

Nanograma

Ânion superóxido

Radicais hidroxil

Nível de significância

Parte por milhão

Hidroperóxido de fosfatidilcolina

Fosfolipídio hidroperóxido glutationa peroxidase

Aglutinina de Pisum sativum

Segundos

Statistical Analysis System (Sistema de Análise Estatística)

Selênio

Selenocisteína

Selenometionina

Superóxido dismutase

Retilinearidade

Meio de Tyrode suplementado com albumina, lactato e piruvato 
TALPm

TBARS

u.a.

VAP

VCL

VSL
Meio de Tyrode suplementado com lactato e piruvato e sem adição de $\mathrm{CaCl} 2 \mathrm{H}_{2} \mathrm{O}$ e $\mathrm{NaHCO}_{3}$

Substâncias reativas ao ácido tiobarbitúrico

Unidades arbitrárias

Velocidade do trajeto

Velocidade curvilinear

Velocidade progressiva 


\section{LISTA DE SÍMBOLOS}

$\begin{array}{ll}{ }^{\circ} \mathrm{C} & \text { graus Celsius } \\ \% & \text { percentagem } \\ \mathrm{x} & \text { vezes } \\ 10^{6} & \text { milhões } \\ 10^{9} & \text { bilhões } \\ : & \text { para (1:100) } \\ { }_{\circledR} & \text { marca registrada } \\ < & \text { menor que } \\ > & \text { maior que } \\ \pm & \text { mais ou menos } \\ - & \text { menos / negativo } \\ + & \text { mais/positivo } \\ = & \text { igual } \\ { }^{\circ} & \text { grau }\end{array}$




\section{SUMÁRIO}

1 INTRODUÇÃO .................................................................................................................29

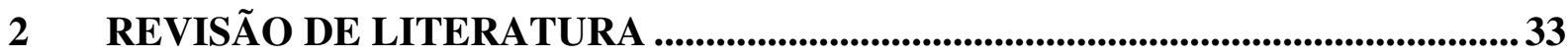

2.1 SELÊNIO E SUA FUNÇÃO NAS CARACTERÍSTICAS SEMINAIS ............................33

2.2 RELAÇÃO DAS ESPÉCIES REATIVAS DE OXIGÊNIO COM AS

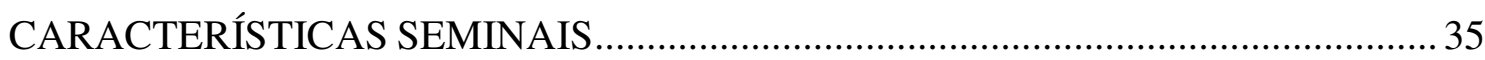

2.3 FONTES DE SELÊNIO E SUA BIODISPONIBILIDADE..............................................

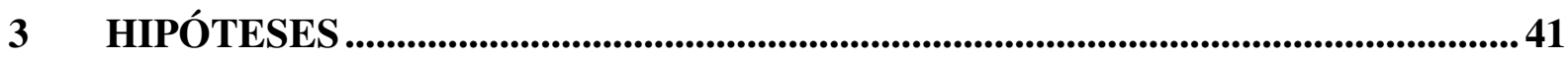

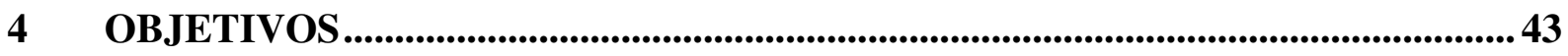

5 MATERIAL E MÉTODO.............................................................................45

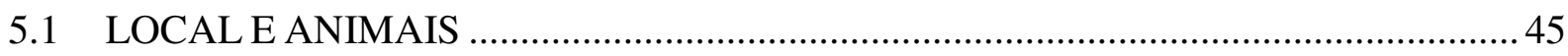

5.2 DISTRIBUIÇÃO DOS ANIMAIS NOS TRATAMENTOS EXPERIMENTAIS ........... 46

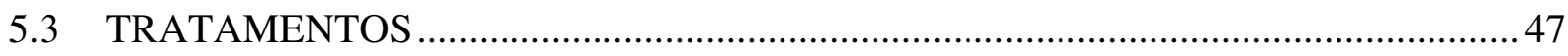

5.4 COLETA E AVALIAÇÕES ESPERMÁTICAS …………………………………..... 51

5.5 AVALIAÇÃO DO VOLUME E CONCENTRAÇÃO ESPERMÁTICA .........................52

5.6 AVALIAÇÃO COMPUTADORIZADA DAS CARACTERÍSTICAS DA

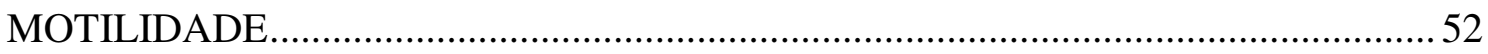

5.7 AVALIAÇÃO DA INTEGRIDADE DAS MEMBRANAS PLASMÁTICA E ACROSSOMAL POR CITOMETRIA DE FLUXO ……………………………….....53

5.8 AVALIAÇÃO DO POTENCIAL DE MEMBRANA MITOCONDRIAL POR

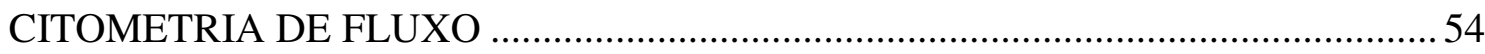


5.9 AVALIAÇÃO DA PEROXIDAÇÃO DAS MEMBRANAS ESPERMÁTICAS

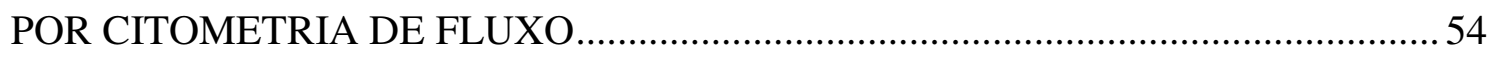

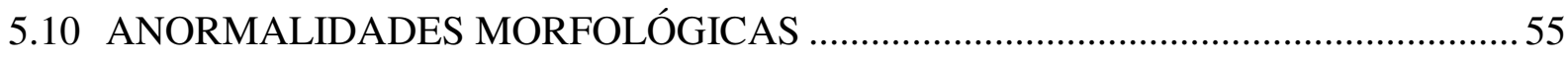

5.11 AVALIAÇÃO DO NÚMERO TOTAL DE ESPERMATOZÓIDES DO EJACULADO E NÚMERO DE DOSES INSEMINANTES ........................................56

5.12 AVALIAÇÃO DA ATIVIDADE DA ENZIMA FOSFOLIPÍDIO HIDROPERÓXIDO GLUTATIONA PEROXIDASE (PHGPx) ...................................56

5.13 ANÁLISE DA BIODISPONIBILIDADE DO SELÊNIO ........................................... 58

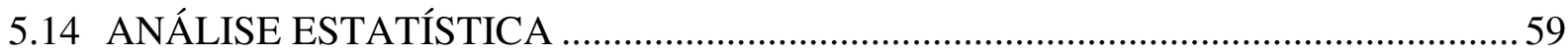

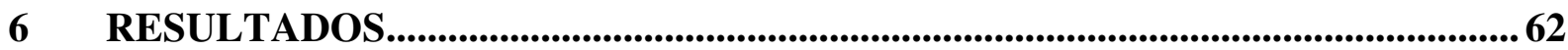

6.1 PARTE 1: EFEITO DA SUPLEMENTAÇÃO ORAL DE SELÊNIO SOBRE AS CARACTERÍSTICAS DO SÊMEN IN NATURA DE CACHAÇOS

6.1.1 EFEITO DO SELÊNIO NO VOLUME, CONCENTRAÇÃO, NÚMERO TOTAL DE CÉLULAS E NÚMERO DE DOSES INSEMINANTES NO SÊMEN IN NATURA

6.1.2 EFEITO DO SELÊNIO NA INTEGRIDADE DA MEMBRANA PLASMÁTICA E ACROSSOMAL, POTENCIAL DE MEMBRANA MITOCONDRIAL E PEROXIDAÇÃO DAS MEMBRANAS NO SÊMEN IN NATURA 66

6.1.3 EFEITO DO SELÊNIO NAS CARACTERÍSTICAS DO MOVIMENTO ESPERMÁTICO NO SÊMEN IN NATURA 69

6.1.4 EFEITO DO SELÊNIO NAS ANORMALIDADES MORFOLÓGICAS NO SÊMEN IN NATURA .73

6.1.5 EFEITO DO SELÊNIO NA ATIVIDADE DA ENZIMA FOSFOLIPÍDIO HIDROPERÓXIDO GLUTATIONA PEROXIDASE (PHGPX) NO SÊMEN IN NATURA .77

6.1.6 CONCENTRAÇÃO DE SELÊNIO NO PLASMA SANGUÍNEO E SEMINAL NAS SEMANAS .78

6.1.7 CORRELAÇÃO ENTRE AS CARACTERÍSTICAS ESPERMÁTICAS E A ENZIMA FOSFOLIPÍDIO HIDROPERÓXIDO GLUTATIONA PEROXIDASE 
6.2 PARTE 2: EFEITO DA SUPLEMENTAÇÃO ORAL DE SELÊNIO SOBRE AS CARACTERÍSTICAS DO SÊMEN REFRIGERADO DE CACHAÇOS.

6.2.1 EFEITO DO SELÊNIO NA INTEGRIDADE DA MEMBRANA PLASMÁTICA E ACROSSOMAL, POTENCIAL DE MEMBRANA MITOCONDRIAL E PEROXIDAÇÃO DAS MEMBRANAS NO SÊMEN REFRIGERADO

6.2.2 EFEITO DO SELÊNIO NAS CARACTERÍSTICAS DO MOVIMENTO ESPERMÁTICO NO SÊMEN REFRIGERADO

6.2.3 EFEITO DO SELÊNIO NAS ANORMALIDADES MORFOLÓGICAS NO SÊMEN REFRIGERADO..... 90

6.2.4 EFEITO DO SELÊNIO NA ATIVIDADE DA ENZIMA FOSFOLIPÍDIO HIDROPERÓXIDO GLUTATIONA PEROXIDASE (PHGPX) NO SÊMEN REFRIGERADO

7 DISCUSSÃO 95

7.1 SÊMEN IN NATURA 95

7.2 SÊMEN REFRIGERADO. 101

8 CONCLUSÃO 106

REFERÊNCIAS 108

ANEXOS 118 


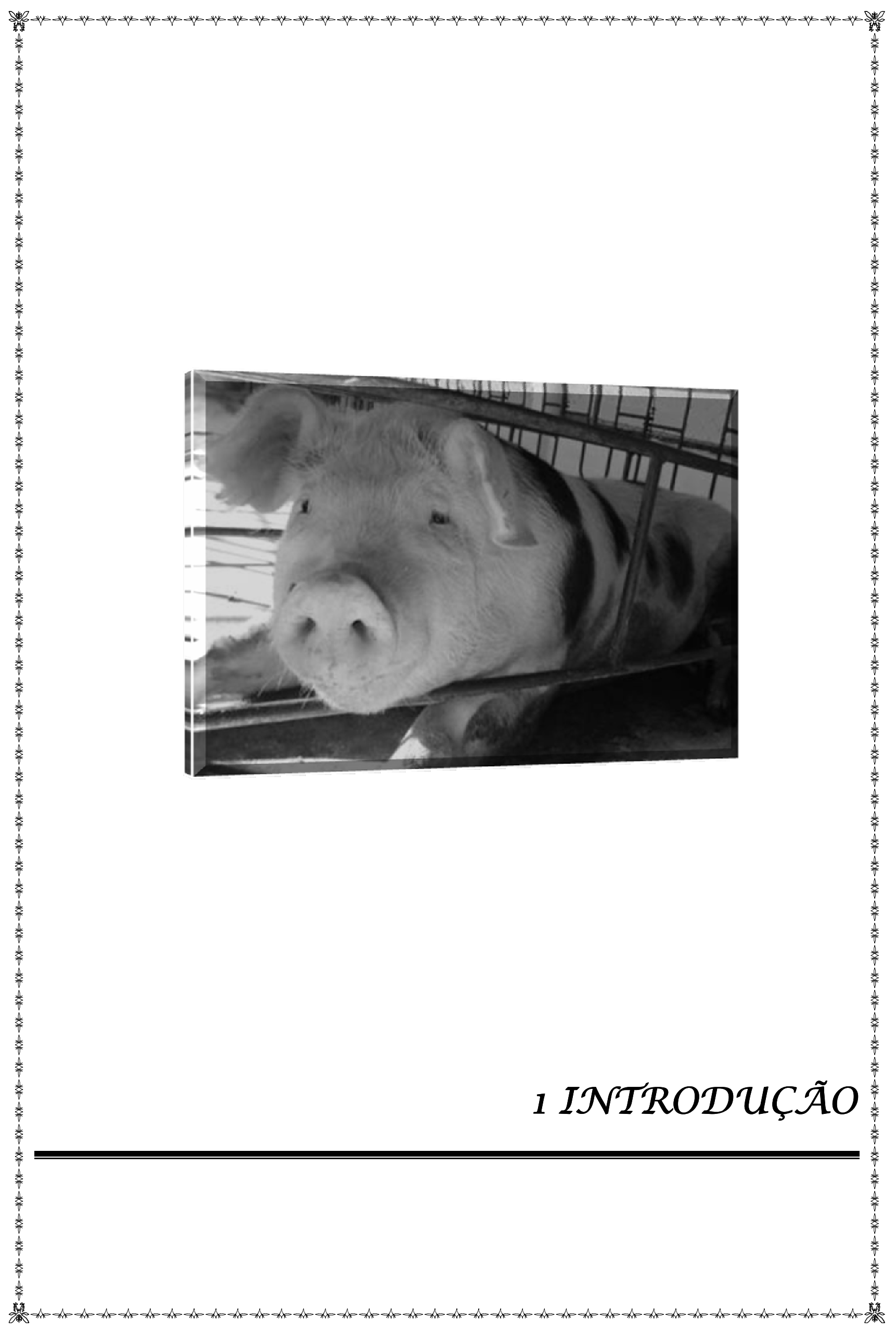




\section{INTRODUÇÃO}

A ampla utilização da técnica de inseminação artificial (IA) em suínos faz com que se investigue mais intensamente os efeitos dos diversos fatores que influenciam a qualidade seminal. Dentre estes, a nutrição vem se destacando por atuar como uma ferramenta para melhorar a qualidade do sêmen.

A possibilidade de se prolongar a vida útil do reprodutor suíno tem adquirido maior atenção por parte dos pesquisadores, uma vez que, o cachaço representa um custo elevado para o sistema de produção e sua vida útil reprodutiva é relativamente curta variando em torno de 3,5 anos de idade.

As exigências nutricionais dos cachaços foram negligenciadas por muitos anos, já que se forneciam aos machos dietas baseadas nas necessidades das matrizes, fato este que contribuí para o aumento das taxas de descarte. Estas taxas variando entre $40 \%$ a $60 \%$ ao ano e ocorrendo principalmente devido ao excesso de peso corporal. $\mathrm{O}$ excesso de peso corporal tem como consequência injúrias no aparelho locomotor que incapacitam os machos para a monta (MUNIZ; NEVES, 2005). Deste modo, a nutrição adequada, além de evitar o sobrepeso pode melhorar as características reprodutivas interferindo na idade à puberdade, na libido, no vigor sexual, no desenvolvimento e na manutenção das glândulas endócrinas (CLOSE; COLE, 2000).

A avaliação do sêmen pode ser realizada por meio de análises convencionais, tais como a concentração, morfologia e motilidade espermática, contudo estes testes apresentam limitações, uma vez que não permitem averiguar a integridade do espermatozóide em sua totalidade (DE ANDRADE et al., 2007). A integridade da membrana espermática é de extrema importância para que a célula mantenha sua capacidade fertilizante. A membrana plasmática é responsável pela preservação da homeostase celular, e deste modo, exerce papel vital na sobrevivência do espermatozóide no trato reprodutivo da fêmea (ÕURA; TOSHIMORI, 1990).

Tem sido sugerido que parte da redução na fertilidade do espermatozóide pode ser devido a danos oxidativos oriundos da formação das espécies reativas de oxigênio (EROs), ou subseqüente peroxidação da membrana lipídica, uma vez que a membrana plasmática do espermatozóide de cachaços apresenta altos níveis de ácidos graxos poliinsaturados (CEROLINI et al., 2000; STUBBS; SMITH, 1984). Contudo, sabe-se que os espermatozóides possuem um sistema de defesa antioxidante contra as EROs, que consiste, principalmente, de 
enzimas como: superóxido dismutase (SDO), catalase, glutationa peroxidase (GPx) dependente de selênio e a redutase, bem como, antioxidante não enzimáticos como: ácido ascórbico (vitamina C) e $\alpha$-tocoferol ou vitamina E (AITKEN, 1995). Especificamente, a célula espermática do suíno contém glutationa peroxidase e $\alpha$-Tocoferol, o que indica que ambos têm importância na prevenção dos danos peroxidativos (MARIN-GUZMAN et al., 1997).

O selênio é um mineral que pode exercer ação antioxidante por possuir sítio ativo na enzima glutationa peroxidase (GPx) (ROTRUCK et al., 1973), esta enzima está presente no sêmen dos animais e em humanos (BEHNE et al., 1996). As selenoenzimas ou selenoproteínas, como também são conhecidas, participam na regulação de várias funções fisiológicas incluindo a proteção antioxidante, a regulação redox da expressão de gene, o metabolismo da tireóide e a manutenção da integridade da estrutura do espermatozóide. De fato, recentemente tem sido demonstrado que a selenoproteína da cápsula mitocondrial da célula espermática de perus é uma forma de glutationa peroxidase, a qual é conhecida por desempenhar um papel importante na estrutura da célula, como uma proteína estrutural (DIMITROV et al., 2007).

Ursini et al. (1999) descobriram, em ratos, a PHGPx (Fosfolipídio Hidroperóxido Glutationa Peroxidase) e relataram sua capacidade de proteger as células espermáticas dos danos oxidativos durante o desenvolvimento. Esta proteína se polimeriza, nos espermatozóides já formados, em uma proteína estrutural presente na cápsula mitocondrial na região da peça intermediária. Como a PHGPx compõem cerca de 50\% do material da cápsula, parece provável que esta polimerização seja a responsável por conferir a integridade estrutural necessária para à estabilidade e motilidade dos espermatozóides. Ressalta-se que até onde foi possível pesquisar não havia relatos da existência, muito menos da função desta enzima no espermatozóide de cachaços até o presente experimento.

Considerando os minerais empregados na alimentação dos cachaços, classicamente divididos em macro e microminerais, encontram-se os macrominerais (ex. Na, K, Ca, P) envolvidos na maioria das funções estruturais e fisiológicas, e os microminerais (ex. $\mathrm{Cu}, \mathrm{Zn}$, $\mathrm{Cr}, \mathrm{Se}$ ), também conhecidos como elementos traço, envolvidos nas funções metabólicas (VIEIRA, 2004). Embora os microminerais venham a exercer influência positiva nas características reprodutivas tanto em fêmeas como em machos, apenas uma pequena parte desses minerais é aproveitado pelos animais devido à formação de complexos de baixa solubilidade no trato digestório, resultando em reduzido aproveitamento quando advindos de fontes inorgânicas. Dessa forma, tem havido o interesse na pesquisa dos minerais orgânicos, 
caracterizados por serem revestidos por aminoácidos, proteínas e leveduras, os quais formam complexos que podem ser caracterizados em: metal aminoácido, metal polissacarídeo e metal proteinado que independente da forma diminui a formação de sais insolúveis, aumentando o aproveitamento e reduzindo a excreção e o impacto ambiental (POWER; HORGAN, 2000).

Sabendo-se da importância do selênio na constituição e manutenção da célula espermática, alguns estudos foram desenvolvidos com o intuito de verificar o efeito da suplementação de selênio sobre determinadas características reprodutivas de cachaços (maturidade sexual, tamanho testicular, volume do ejaculado, concentração espermática, morfologia e motilidade espermática) (LOPEZ et al., 2010; MARIN-GUZMAN et al., 1997; MARIN-GUZMAN et al., 2000a; MARIN-GUZMAN et al., 2000b; SEGERSON et al., 1981). Estas pesquisas foram realizadas com a inclusão de diferentes níveis (0 e 0,5 ppm de selenito de sódio) (MARIN-GUZMAN et al., 1997; MARIN-GUZMAN et al., 2000a; MARIN-GUZMAN et al., 2000b) e testando diferentes fontes de selênio (0,40 ppm de selênio levedura e selenito de sódio) (LOPEZ et al., 2010). Porém, em nenhum destes experimentos foram avaliados os efeitos da suplementação associada ao uso de diferentes fontes de selênio (orgânico e inorgânico) na integridade das membranas plasmática e acrossomal, no potencial de membrana mitocondrial e na atividade da enzima PHGPx, seja no sêmen in natura, ou após seu armazenamento por 72 horas à $18^{\circ} \mathrm{C}$. 


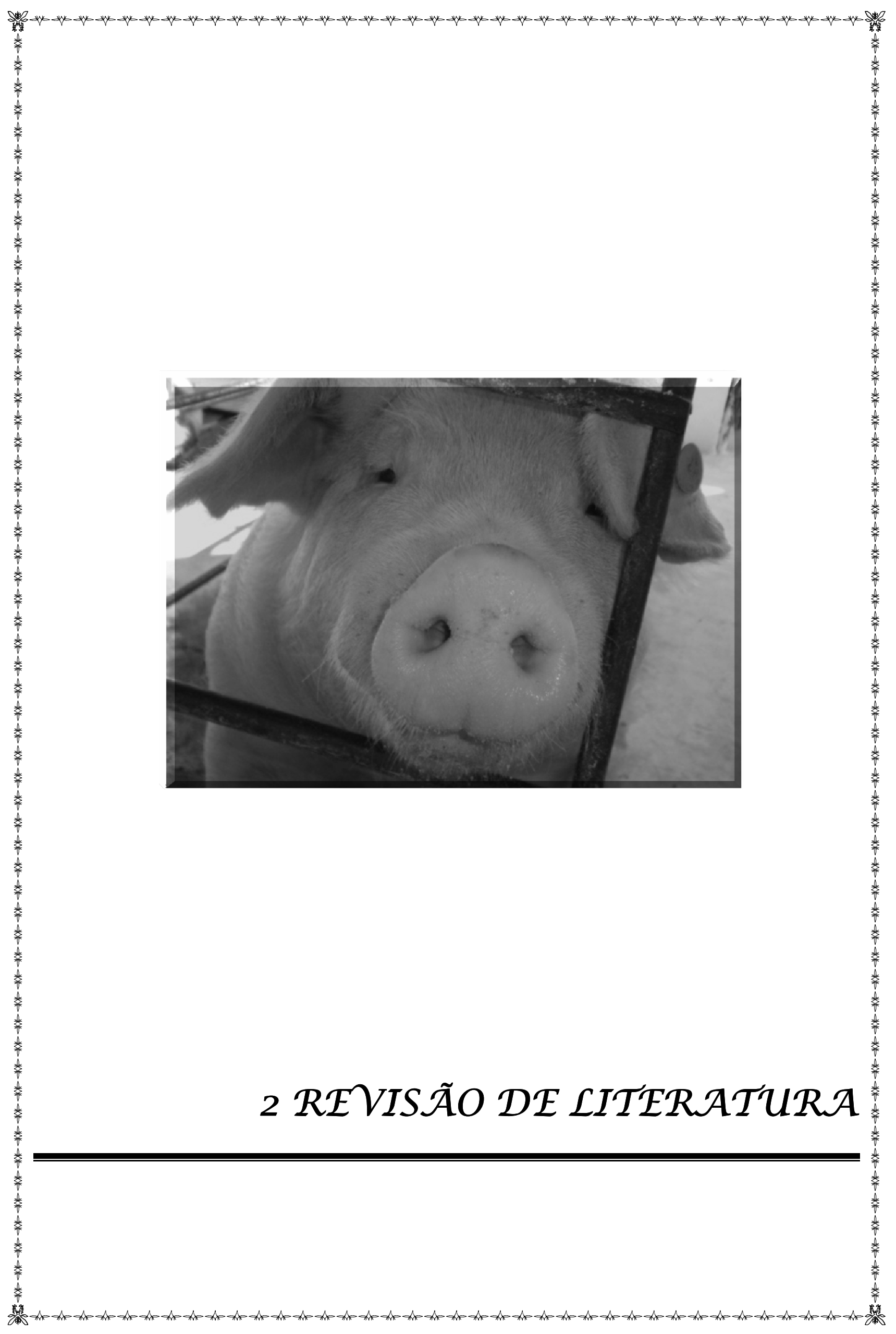




\section{REVISÃO DE LITERATURA}

\subsection{SELÊNIO E SUA FUNÇÃO NAS CARACTERÍSTICAS SEMINAIS}

O selênio é essencial para a fertilidade de roedores machos e tem sido associado à capacidade fertilizante de espermatozóides de humanos e animais de produção (BROWN; BURK, 1973). Este mineral estimula o desenvolvimento e o aumento das células de Sertoli, sendo este efeito mais evidenciado em cachaços que estão atingindo a maturidade sexual. Além disso, parece ser fundamental em todos os estágios do desenvolvimento testicular (MARIN-GUZMAN et al., 2000a), sendo necessário não somente para o desenvolvimento das células germinativas durante fase inicial de desenvolvimento do animal, mas também afetando o número das mesmas no cachaço adulto (GOULD, 1970).

Este micromineral exerce função biológica associada ao aminoácido cisteína formando o complexo selenocisteína que é incorporado às estruturas primárias da família das selenoproteínas (BROWN; BURK, 1973). Mais de 20 selenoproteínas têm sido identificadas, e incluem enzimas importantes para a defesa antioxidante, tais como a glutationa peroxidase e a tioredoxina redutase (KRYUKOV et al., 2003). As selenoproteínas são usualmente enzimas que contêm na molécula a selenocisteína simples associado a um constituinte que caracteriza um sítio ativo específico (OLSON et al., 2005).

A deficiência de selênio está associada à diminuição na motilidade espermática e aumento nas alterações estruturais da peça intermediária e cauda dos espermatozóides (BROWN; BURK, 1973). No espermatozóide, a maior parte do selênio está presente na cápsula mitocondrial, uma matriz semelhante à queratina que envolve a estrutura espiralada da mitocôndria na peça intermediaria (CALVIN et al., 1981).

O selênio, atuando como componente das selenoproteínas, exerce função marcante na qualidade do sêmen. As selenoproteínas têm sido identificadas na membrana mitocondrial externa do espermatozóide em ratos (BROWN; BURK, 1973) e touros (PALLINI; BACCI, $1979^{1}$ apud MARIN-GUZMAN et al., 2000b, p. 1544), sugerindo que o selênio exerce influência no desenvolvimento da célula espermática. Dietas inadequadas para reprodutores suínos reduzem a motilidade espermática e aumentam as anormalidades morfológicas,

\footnotetext{
1 PALLINI, V., BACCI, E. Bull sperm selenium is bound to a structural protein of mitochondria. J.
} Submicrosc. Cytol. v. 11, p. 165-170, 1979. 
principalmente às relacionadas à peça intermediária (mitocôndrias), havendo menor concentração de ATP e menor atividade da enzima GPx (MARIN-GUZMAN et al., 1997).

Em ratos, foi observado por Lane et al. (1979) que o aumento nas concentrações de selênio, nem sempre correspondem ao aumento na atividade da GPx, indicando que esta enzima não poderia ser usada para monitorar os níveis de selênio em ratos.

Os resultados encontrados por Marin-Guzman et al. (1997), utilizando a concentração de 0,50 ppm de selênio inorgânico (selenito de sódio), sugerem que o parênquima testicular tem elevada exigência de selênio, evidenciado pelo aumento do parênquima testicular e atividade da enzima GPx. Esse selênio testicular aumentado resultou em elevada concentração de selênio na célula espermática, além de elevada atividade da enzima glutationa peroxidase, sugerindo um papel funcional, além de influência na morfologia da cauda.

Dados na literatura sugerem que a exigência de selênio para a maioria das espécies de produção está entre 0,05 e $0,3 \mathrm{mg} / \mathrm{Kg}$ de matéria seca ingerida. Esta quantidade varia de acordo com diferentes fatores que podem influenciar o requerimento de um animal, como pela diversidade de opiniões quanto aos critérios usados para estabelecer as exigências. Os fatores como as fontes de selênio, a biodisponibilidade, as concentrações de antagonistas como ferro, enxofre e cobre na dieta podem influenciar a determinação da exigência de selênio (KIEFER, 2005). A literatura sugere que a exigência de selênio para cachaços adultos deve ser de 0,3 $\mathrm{mg} / \mathrm{Kg}$ (CLOSE; COLE, 2000).

A PHGPx é uma selenoproteína pertencente a família das glutationas peroxidases. A PHGPx tem sido considerada como a maior enzima antioxidante que conjuntamente com a vitamina E, protegem as biomembanas (URSINI et al., 1982) e inibem a biosíntese dos leucotrienos (WEITZEL; WENDEL, 1993). O selênio concentra-se na peça intermediária, incorporado a proteínas estruturais de 20kDa (CALVIN et al., 1981). Essa selenoproteína compõem cerca de $50 \%$ do material da cápsula mitocondrial e seu papel como proteína estrutural, pode explicar o mecanismo de instabilidade da peça intermediária que é observado em situações de deficiência de selênio (URSINI et al., 1999).

Recentemente, foi descoberto que PHGPx, também conhecida como GPx 4, tem dupla função na célula espermática. Ela é enzimaticamente ativa na espermátide, funcionando como uma proteína estrutural no espermatozóide e pode reagir com o peróxido de hidrogênio e uma ampla variedade de hidroperóxidos de lipídios, sendo, portanto, considerada responsável pela proteção da membrana contra os danos oxidativos (FORESTA et al., 2002; IMAI; NAKAGAWA, 2003). A integridade estrutural da peça intermediária do espermatozóide é garantida através do processo de polimerização da PHGPx, proteína a qual também reduz 
peróxido e usa tióis como substrato para a oxidação durante o desenvolvimento testicular (BERTELSMANN et al., 2007).

A PHGPx é encontrada no testículo na forma de três isoformas que são derivadas dos mesmos genes. Essas isoformas se localizam no citosol, mitocôndria e núcleo, tendo a função de auxiliar no desenvolvimento dos espermatozóides, a medida que atuam protegendo contra espécies reativas de oxigênio (EROS). E parece, portanto, ser essencial para a função espermática, uma vez que, a redução dos seus níveis no espermatozóide de humanos tem sido relacionada a infertilidade (IMAI et al., 2001).

As mitocôndrias localizadas na peça intermediária ao redor da parte principal da cauda do espermatozóide são responsáveis pela síntese de ATP através da fosforilação oxidativa, evidenciando sua importância na motilidade espermática. Modificações na síntese de ATP alteram a concentração de ATP mitocondrial, que por sua vez, poderiam alterar o metabolismo energético e, conseqüentemente a função da célula espermática (MARINGUZMAN et al., 2000b).

Os resultados encontrados por Marin-Guzman et al. $(1997 ; 2000 \mathrm{~b})$ indicaram que o selênio pode ter diversos papéis funcionais no testículo. $\mathrm{O}$ estrutural, no desenvolvimento da peça intermediária, no desenvolvimento e no número de células de Sertoli e como componente da enzima glutationa peroxidase no sêmen. Em situação de deficiência os primeiros sinais observados são a redução na motilidade e no percentual de espermatozóides normais. Além disso, Marin-Guzman et al. (2000a) relataram que provavelmente em situações de elevada freqüência de coleta, os sinais poderiam estar mais exacerbados, sugerindo que os cachaços deveriam receber uma dieta diferenciada com maiores níveis de selênio de acordo com a frequiência de coleta de sêmen.

\subsection{RELAÇÃO DAS ESPÉCIES REATIVAS DE OXIGÊNIO COM AS CARACTERÍSTICAS SEMINAIS}

O espermatozóide possui um sistema intracelular de defesa antioxidante contra os EROS, que consiste, principalmente, de enzimas como: superóxido dismutase (SDO), catalase, glutationa peroxidase (GPx) (enzima composta por selênio) e a redutase, bem como, antioxidante não enzimáticos como: ácido ascórbico (vitamina C) e $\alpha$-tocoferol (vitamina E) (AITKEN, 1995). 
A glutationa peroxidase (GPx) catalisa a redução do peróxido de hidrogênio $\left(\mathrm{H}_{2} \mathrm{O}_{2}\right)$ e outros peróxidos orgânicos. Esta sendo encontrada no citosol, na mitocôndria e na membrana plasmática (FERREIRA; MATSUBARA, 1997).

Sabe-se que a suplementação de selênio na dieta aumenta a atividade da glutationa peroxidase no sêmen de coelhos, mas não a estabilidade oxidativa dos espermatozóides (CASTELLINI et al., 2002) e que a adição de antioxidantes, entre eles, a glutationa peroxidase prolonga o período de conservação do sêmen de carneiros, melhorando a motilidade e reduzindo o grau de danos celulares.

O excesso de produção dos EROS está associado ao decréscimo da motilidade, ao aumento das anormalidades morfológicas e a baixa capacidade do espermatozóide em penetrar no oócito (AITKEN; CLARKSON, 1987; AITKEN; CLARKSON; FISHEL, 1989; AITKEN; FISHER, 1994).

A peroxidação lipídica dos ácidos graxos poli-insaturados, por ação do excesso de EROS, diminui a fluidez e aumenta a rigidez da membrana plasmática. Simultaneamente, peróxidos lipídicos são gerados neste processo e seus produtos de degradação, como o malondialdeído (MDA). Estes metabólitos podem inibir várias enzimas e funções espermáticas, incluindo a função mitocondrial com a perda da motilidade (ZHENG; ZHANG, 1997; OLIVEIRA, 2003). Previamente, a detecção da peroxidação lipídica ocorrida na membrana espermática era baseada na mensuração dos produtos finais deste processo, seja através da mensuração do malondialdeído ou do 4-hidroxialquenois (NICHI, 2003; GOMEZ, IRVINE, AITKEN, 1998).

Deve ser compreendido que as formações das substâncias reativas ao ácido tiobarbitúrico (TBARS) provenientes das reações ocorridas com os fosfolipídios da membrana necessitam de sucessivas reações químicas e de produtos intermediários formados durante estas reações (ex. hidroperóxidos lipídeos, -epoxidos, -endoperoxidos). Os exemplos mais bem conhecidos de rotas alternativas são as reduções enzimáticas dos fosfolipídios hidroperóxidos pela enzima PHGPx (BROUWERS; GADELLA, 2003).

A sonda fluorescente C11-BODIPY ${ }^{581 / 591}$ supre as limitações das técnicas baseadas nas TBARS. Esta sonda é um análogo dos ácidos graxos poli-insaturados sendo prontamente incorporada à membrana celular. Sua reatividade à peroxidação é comparável a dos ácidos graxos poli-insaturados, encontrados em abundância nas membranas das células espermáticas.

Ao ter contato com as espécies reativas de oxigênio, a fluorescência desta sonda muda irreversivelmente da cor vermelha para a verde e por este motivo vem sendo usada para acessar a peroxidação lipídica e a oxidabilidade de células vivas, sendo descrita para células 
do miocárdio, fibroblastos, e espermatozóides bovinos e eqüinos (PAP et al., 1999; BALL; VO, 2002; BROUWERS; GADELLA, 2003).

\subsection{FONTES DE SELÊNIO E SUA BIODISPONIBILIDADE}

O selênio utilizado na alimentação dos animais pode ser encontrado na forma inorgânica, selenito de sódio $\left(\mathrm{Na}_{2} \mathrm{SeO}_{3}\right)$ ou selenato de sódio $\left(\mathrm{Na}_{2} \mathrm{SeO}_{4}\right)$, e orgânica, selenometionina (SeMet) ou selenocisteína (SeCis) (TODD; HENDRIKS, 2005).

Os minerais orgânicos, também chamados de quelatados, são compostos formados pela ligação entre um íon metálico e um carreador orgânico, normalmente aminoácidos ou carboidratos (LEESON; SUMMERS, 1997). Os carreadores são acoplados aos minerais por ligações covalentes utilizando o grupo amino ou oxigênio. Esta ligação covalente torna a carga elétrica da molécula praticamente nula.

Os minerais quelatados foram definidos por Leeson; Summers (1997) como sendo uma mistura de elementos minerais a algum tipo de carreador, o qual pode ser um aminoácido ou polissacarídeo que possuem a capacidade de se ligar ao metal através de ligações covalentes. Ensminger; Oldfield (1990) relataram que esses quelantes, por sua vez, têm o papel de aumentar a absorção e a biodisponibilidade desse mineral no organismo, além de aumentar a sua estabilidade física, reduzindo assim a tendência do micromineral se separar do alimento.

Estes minerais orgânicos podem ser obtidos a partir da hidrólise de proteína e a exposição do elemento mineral ao hidrolisado resulta na formação de complexos íons metálicos quelatados (HYNE; KELLY, 1995) ou ainda podem ser sintetizados por leveduras.

O termo biodisponibilidade pode ser definido de várias maneiras, sendo descrito em 1983 por Forbes; Erdman como o reflexo da eficiência com o qual os nutrientes são consumidos e absorvidos pelo trato gastrointestinal. Em 1992, Fairweather-Tait definiu-a como a proporção de minerais por nutriente utilizado nas funções corpóreas. Portanto, a biodisponibilidade envolve tanto a absorção quanto a utilização metabólica do nutriente pela célula.

Inúmeros fatores intrínsecos e extrínsecos podem afetar a biodisponibilidade dos minerais inorgânicos, tais como: a própria forma química do elemento, a presença de íons 
inorgânicos que competem pelo mesmo mecanismo, a interação de minerais com moléculas carreadoras que podem aumentar ou diminuir a absorção do mesmo, além da idade, sexo e fase do desenvolvimento. Paralelamente, o pH (secreção gastrointestinal) e a microflora também interferem sobremaneira na biodisponibilidade (FAIRWEATHER-TAIT, 1996).

Os minerais orgânicos apresentam melhor biodisponibilidade em comparação aos inorgânicos, porque há uma maior estabilidade elétrica no lúmen intestinal e, ainda, são prontamente transportados para os tecidos, onde permanecem por períodos mais longos que os minerais tradicionais (CLOSE, 1998).

A absorção dos minerais inorgânicos no intestino ocorre por difusão passiva ou transporte ativo, ou seja, é necessário que estejam associados a um ligante ou uma molécula transportadora. Na maioria das vezes estes íons não encontram o agente ligante e acabam sendo excretados (HERRICK, 1993).

Os minerais orgânicos apresentam absorção superior, pois geralmente utilizam as vias de absorção das moléculas orgânicas, as quais estão associadas, evitando que haja interação com outros minerais. A absorção, portanto, pode ocorrer de duas maneiras, o mineral pode se ligar e ser absorvido pelas células epiteliais ou o ligante é absorvido, carreando consigo o mineral. A melhor utilização do mineral se deve a capacidade do ligante de seqüestrar o mineral, ou de sua habilidade em competir com outros ligantes (KRATZER; VOHRA, 1996).

O selênio na forma orgânica de selenometionina é absorvido pelo trato digestório através de mecanismo ativo, semelhante à absorção da metionina, enquanto o inorgânico ou a selenocisteína não são ativamente transportados (LEESON; SUMMERS, 2001). No entanto, a selenometionina é rapidamente absorvida e retida no organismo, mas é vagarosamente convertida em selenocisteína, a qual é necessária para a síntese de proteínas funcionais (UNDERWOOD, 1999), podendo ser incorporada em tecidos com alta taxa de síntese proteica como os músculos esqueléticos, o pâncreas, o fígado, os rins, e o intestino (SCHRAUZER, 2000).

Após o selênio ser absorvido principalmente pelo duodeno e jejuno, este mineral é convertido em selenídeo de hidrogênio, independentemente da fonte, tanto a selenometionina como o selenito de sódio. O selenídeo formado pode ser utilizado na síntese das selenoproteínas e o excedente é transformado em formas metiladas como metilselenol e o trimetilselenônio, os quais são elimindaos pela urina (FRANCESCONI; PANNIER, 2004). Em casos de níveis muito elevados de selênio, a via respiratória passa a ser uma forma complementar de excreção na forma de dimetil-selenol (SCHRAUZER, 2000), conforme figura 1 . 


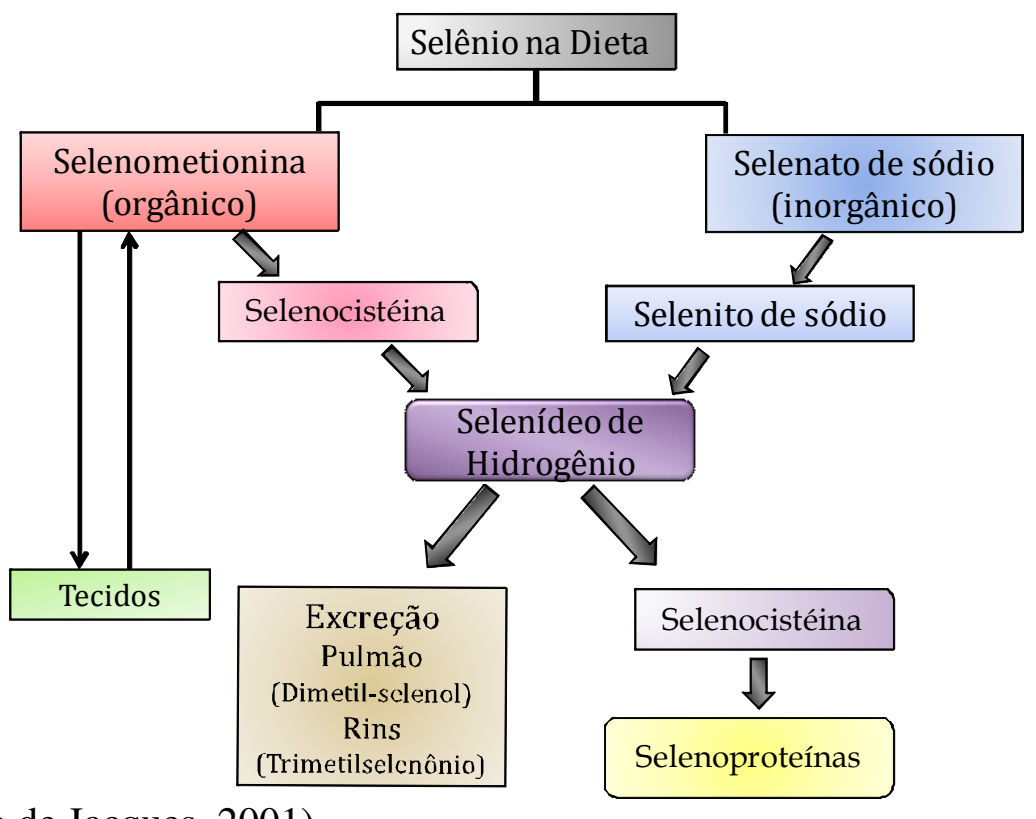

Fonte: (Adaptado de Jacques, 2001).

Figura 1 - Metabolismo, armazenamento, excreção e utilização do selênio nas espécies monogástricas.

Em ratos, a absorção intestinal de selenito e selenometionina é equivalente a $92 \%$ e $96 \%$, respectivamente, mas a retenção total no corpo indicou que a excreção do selenito absorvido foi maior do que a selenometionina (THOMPSON; STEWART, 1973).

A biodisponibilidade relativa do selênio, avaliada através da atividade da glutationa peroxidase, não demonstrou diferença entre as fontes orgânica e inorgânica em aves (AMMERMMAN et al., $1995^{2}$ apud KIEFER, 2005, p. 208). Contudo, Close (1998) verificou que o selênio orgânico apresenta maior biodisponibilidade de 120 a 150\% em comparação ao selenito de sódio (100\%).

Os minerais orgânicos (quelatados) geralmente são mais caros do que as fontes inorgânicas. Entretanto, foi sugerido por Kiefer (2005) que para a utilização destes minerais deve-se ter visão diferenciada, pois o custo elevado pode ser compensado pela melhor digestibilidade e maior absorção pelos animais através da parede intestinal.

Dessa forma, tem havido o interesse na pesquisa dos minerais orgânicos, os quais formam complexos que podem ser caracterizados em: metal aminoácido, metal polissacarídeo e metal proteinado que independente da forma diminui a formação de sais insolúveis, diminuindo a excreção e o impacto ambiental (POWER; HORGAN, 2000).

2 AMMERMAN, C.B., BAKER, D.H., LEWIS, A.J. Bioavailability of nutrients for animals: amino acids, minerals and vitamins. San Diego: Academic Press, 1995. 441p. 


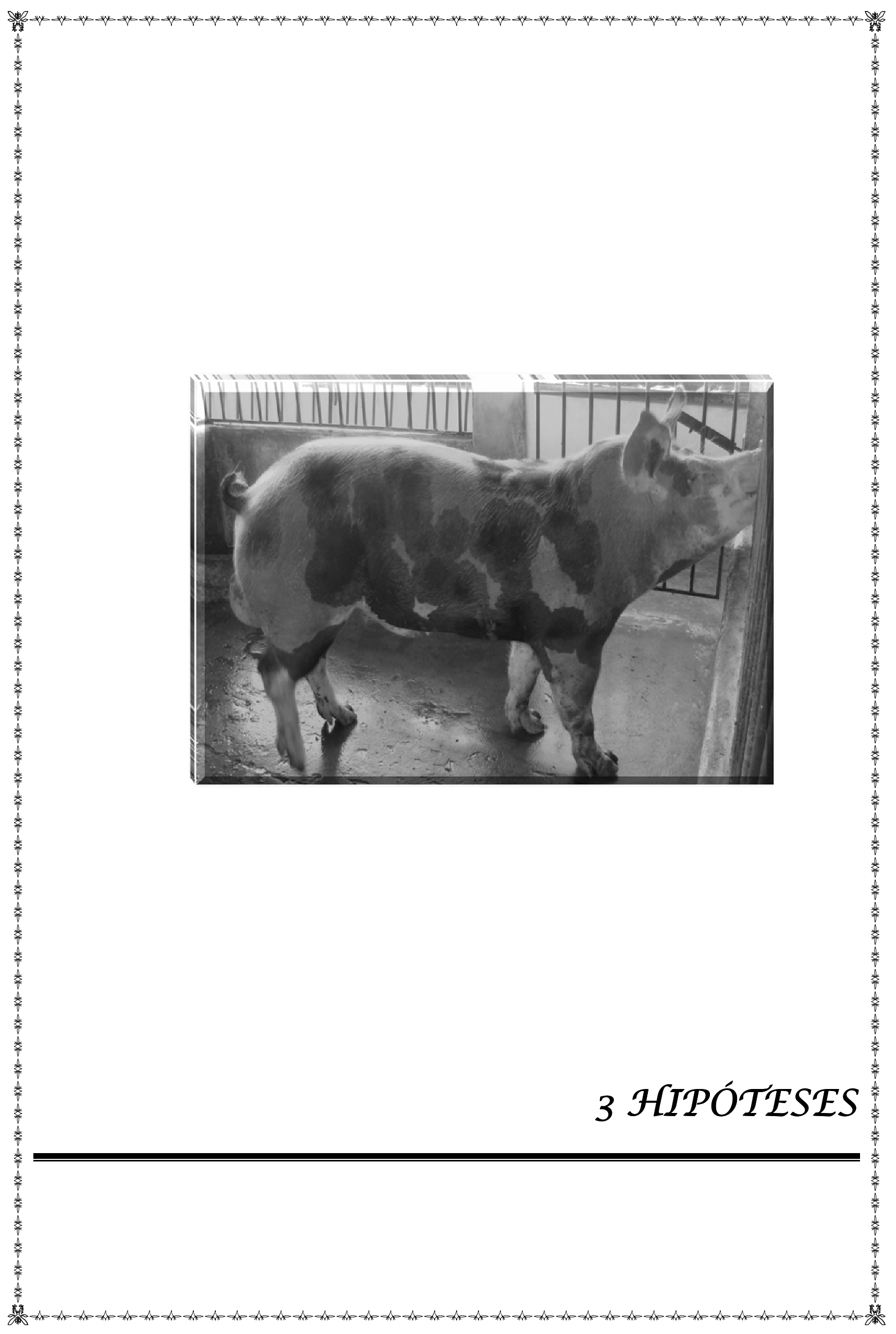




\section{HIPÓTESES}

Diante do exposto, e baseado nos resultados advindos da literatura foram sugeridas as seguintes hipóteses:

1. A suplementação oral de cachaços com selênio orgânico melhora as características seminais no sêmen in natura.

2. Os cachaços suplementados com selênio orgânico na dieta mantêm as características seminais normais no sêmen refrigerado no decorrer do tempo (0, 24, 48 e 72 horas após a diluição).

3. Os animais alimentados com selênio levedura (orgânico) na dieta apresentam maior concentração de selênio no plasma sangüíneo e seminal em comparação aos animais que foram alimentados com selenito de sódio (inorgânico).

4. A maior concentração de selênio no plasma seminal aumenta a atividade da enzima fosfolipídio hidroperóxido glutationa peroxidase no espermatozóide suíno, melhorando a motilidade espermática, a integridade das membranas acrossomal e plasmática e reduzindo as anormalidades morfológicas no sêmen in natura e refrigerado de cachaços.

5. O aumento da atividade da enzima fosfolipídio hidroperóxido glutationa peroxidase na célula espermática de cachaços melhora o potencial de membrana mitocondrial e reduz a peroxidação lipídica das membranas espermáticas no sêmen in natura e refrigerado. 


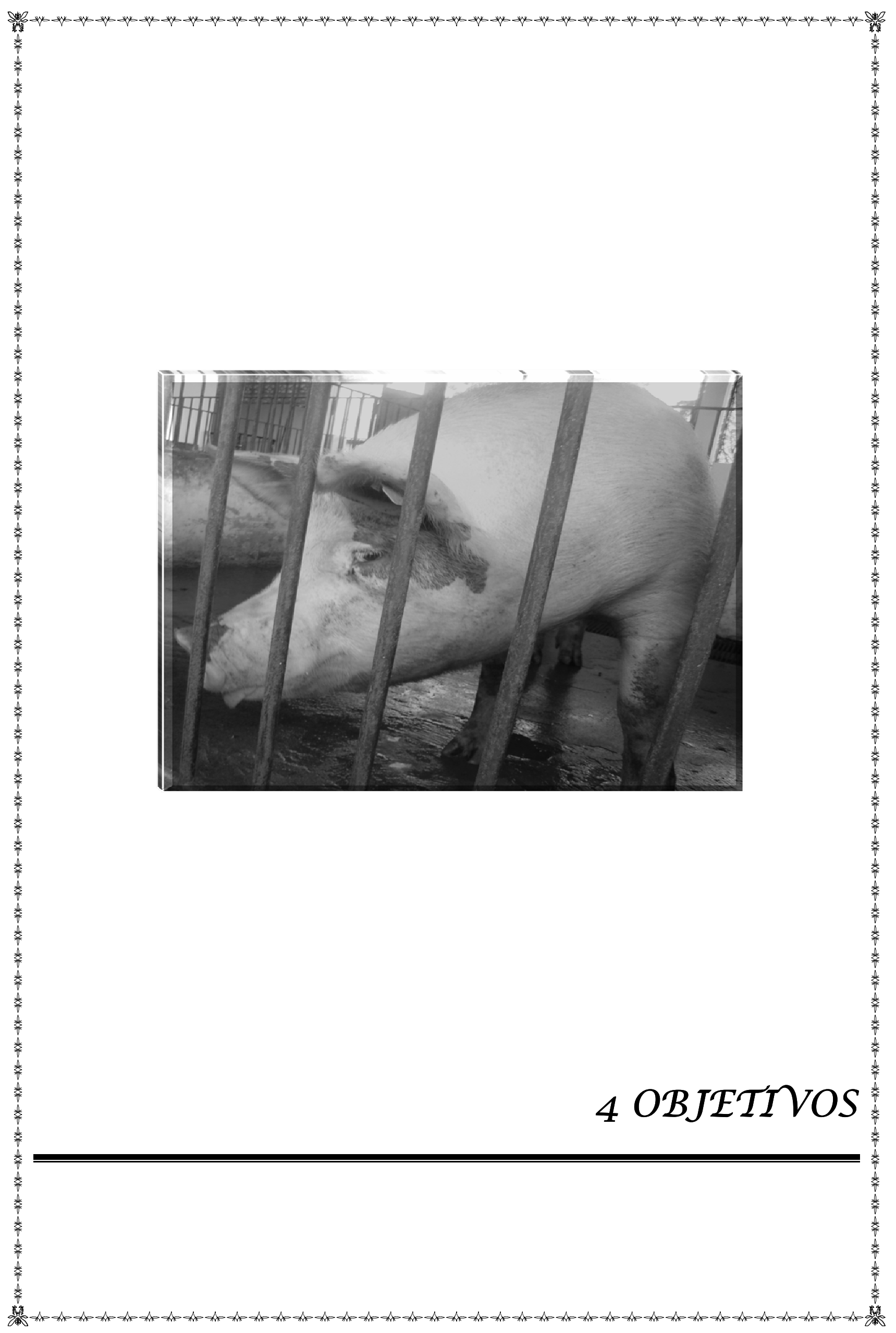




\section{OBJETIVOS}

Com base na literatura apresentada e nas hipóteses formuladas, o experimento foi realizado com os seguintes objetivos:

1. Averiguar os efeitos da suplementação de selênio levedura (orgânico) nas características espermáticas (motilidade, concentração, volume, número total de células, anormalidades morfológicas e integridade das membranas plasmática e acrossomal) no sêmen in natura de cachaços.

2. Constatar os efeitos da suplementação de selênio levedura (orgânico) nas características espermáticas (motilidade, concentração, volume, número total de células, anormalidades morfológicas e integridade das membranas plasmática e acrossomal) no sêmen refrigerado de cachaços no decorrer do tempo (0, 24, 48 e 72 horas após a diluição).

3. Verificar se o fornecimento de selênio levedura (orgânico) na dieta aumenta a concentração de selênio no plasma sangüíneo e seminal.

4. Avaliar se a suplementação de selênio levedura (orgânico) na dieta aumenta a atividade da enzima fosfolipídio hidroperóxido glutationa peroxidase no espermatozóide suíno no sêmen in natura e refrigerado.

5. Determinar se o aumento da atividade da enzima fosfolipídio hidroperóxido glutationa peroxidase diminui a geração de espécies reativas de oxigênio, por meio da avaliação da peroxidação lipídica das membranas espermáticas de suínos e melhora o potencial de membrana mitocondrial no sêmen in natura e refrigerado.

6. Averiguar se a atividade da enzima fosfolipídio hidroperóxido glutationa peroxidase reduz as anormalidades morfológicas na célula espermática no sêmen in natura e refrigerado. 


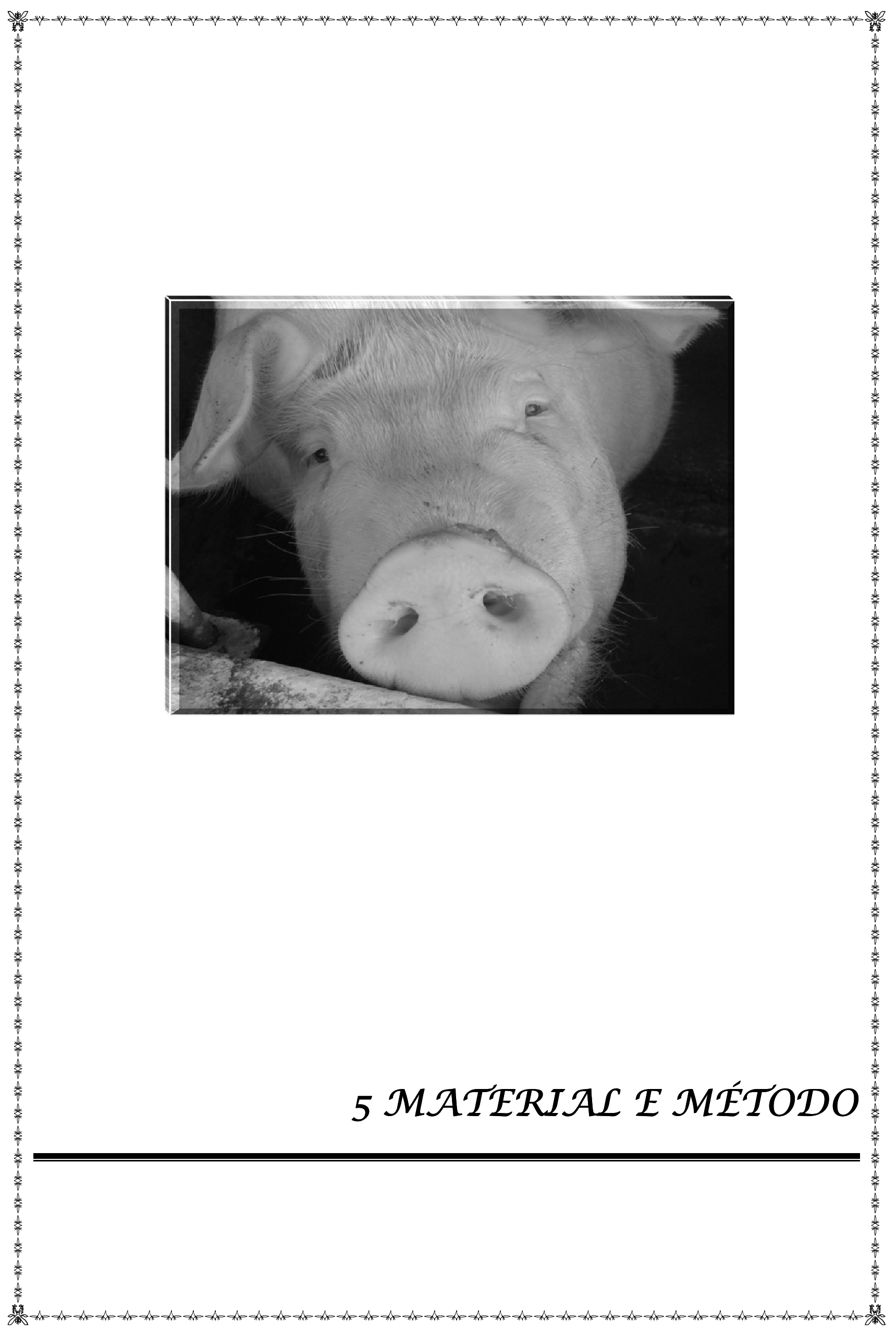




\section{MATERIAL E MÉTODO}

\subsection{LOCAL E ANIMAIS}

Os cachaços foram alojados no Laboratório de Pesquisa em Suínos do Departamento de Nutrição e Produção Animal, em baias individuais com metragem de 9,76 m²/animal, providas de comedouro de alvenaria e bebedouro tipo chupeta. As análises do sêmen foram realizadas no Laboratório de Biotecnologia do Sêmen e Andrologia do Centro de Biotecnologia em Reprodução Animal, pertencentes à Faculdade de Medicina Veterinária e Zootecnia da Universidade de São Paulo (FMVZ, USP), Campus Pirassununga (Figuras 2 e 3, respectivamente).

Foram utilizados 12 cachaços adultos com aproximadamente 18 meses de idade e 257,62 Kg de peso vivo médio, provenientes da granja Novo Milênio, Granja de Reprodutores Suídeos Certificada (GRSC), localizada no município de Campos Novos, Santa Catarina.

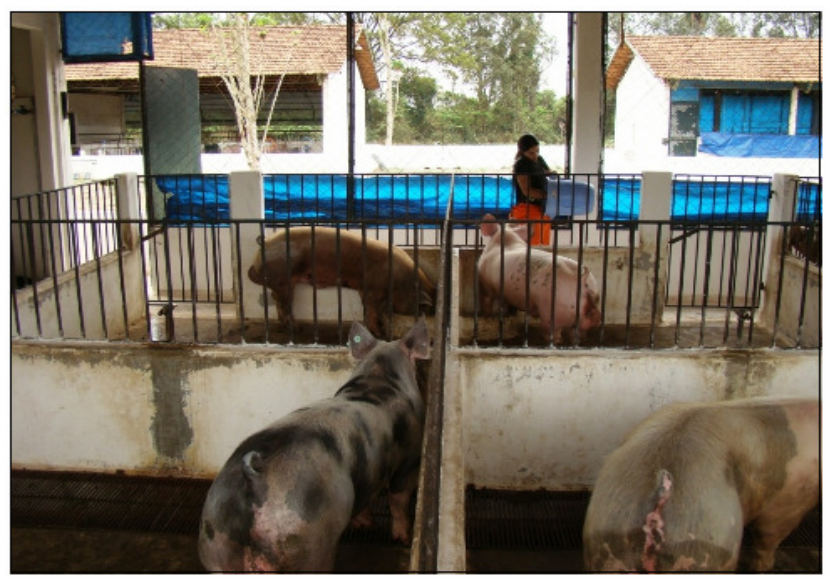

Figura 2- Alojamento dos cachaços no Laboratório de Pesquisa em Suínos (FMVZ-USP) 


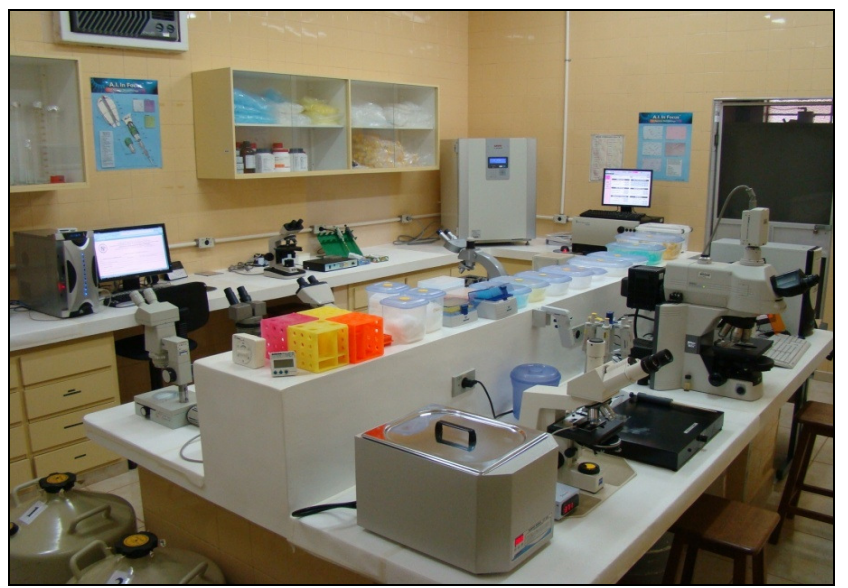

Figura 3 - Laboratório de Biotecnologia do Sêmen e Andrologia (FMVZ-USP)

\subsection{DISTRIBUIÇÃO DOS ANIMAIS NOS TRATAMENTOS EXPERIMENTAIS}

Previamente ao início do experimento, foram realizadas três coletas de sêmen com intervalo semanal para avaliar as características do ejaculado (físicas e morfológicas). A partir desses resultados, os animais foram separados nos grupos experimentais, de modo a minimizar a influência do animal nos tratamentos.

Com base nas avaliações de presença de defeitos espermáticos maiores, menores e motilidade foram calculados os valores médios para cada característica, segundo a fórmula demonstrada na figura 4. Cada animal recebeu uma nota e quanto menor a nota, melhor o sêmen. Os defeitos foram avaliados de acordo com as recomendações do Colégio Brasileiro de Reprodução Animal (CBRA, 1998).

NOTA DO CACHAÇO $=(3 \times T D M A)+(2 \times T D M E)+(1 \times I M)$, onde:

TDMA: Total de defeitos maiores;

TDME: Total de defeitos menores;

IM: Inverso da motilidade.

Figura 4 - Fórmula utilizada para a distribuição dos cachaços nos tratamentos 


\subsection{TRATAMENTOS}

Os cachaços foram distribuídos nos três tratamentos: CONTROLE - dieta formulada utilizando fonte inorgânica (0,30 ppm de selenito de sódio) (NRC, 1998), INORGÂNICO - dieta formulada utilizando fonte inorgânica (0,50 ppm de selenito de sódio) (MARIN-GUZMAN et al., 1997, 2000a, 200b) e ORGÂNICO - dieta formulada utilizando fonte orgânica (0,50 ppm de selênio levedura) (Sel-Plex ${ }^{\circledR}$, Alltech, Inc.) (Tabela 1). A ração foi fornecida duas vezes ao dia, na quantidade de $2,6 \mathrm{Kg} / \mathrm{animal} / \mathrm{dia}$.

Durante o período de condicionamento dos cachaços ao manequim, todos os animais foram alimentados com uma dieta basal contendo 0,30 ppm de selenito de sódio, seguindo as recomendações do NRC (1998). A ração foi fornecida duas vezes ao dia, na quantidade de 2,0 $\mathrm{Kg} /$ animal/dia.

Tabela 1 - Composição das dietas fornecida aos cachaços dos tratamentos (Continua)

\section{DIETAS}

CONTROLE INORGÂNICA ORGÂNICA

\begin{tabular}{llll}
\hline INGREDIENTES & & & \\
\hline Milho & 66,04 & 65,973 & 66,123 \\
\hline Farelo de soja & 17,39 & 17,39 & 17,39 \\
\hline Casca de soja & 10,79 & 10,79 & 10,53 \\
\hline Fosfato bicálcico & 2,01 & 2,01 & 2,01 \\
\hline Açucar & 2 & 2 & 2 \\
\hline Sal comum & 0,6 & 0,6 & 0,6 \\
\hline Calcário & 0,27 & 0,27 & 0,36 \\
\hline Premix Repr. Agroceres & 0,4 & 0,4 & 0,4 \\
\hline Mineral Sui ORG Se & 0 & 0 & 0,167 \\
\hline Mineral Sui INO Se & 0,1 & 0,167 & 0 \\
\hline Metionina & 0,15 & 0,15 & 0,15 \\
\hline Lisina & 0,25 & 0,25 & 0,27 \\
\hline
\end{tabular}


(Conclusão)

\section{DIETAS}

CONTROLE INORGÂNICA

ORGÂNICA

\begin{tabular}{llll}
\hline NívEIS NUTRICIONAIS & & & \\
\hline Proteína Bruta \% & 16 & 16 & 16 \\
\hline Gordura \% & 3,08 & 3,08 & 3,08 \\
\hline Fibra Bruta \% & 5,8 & 5,8 & 5,9 \\
\hline Cálcio \% & 0,75 & 0,75 & 0,75 \\
\hline Fósforo Total \% & 0.65 & 0.65 & 0.65 \\
\hline E. Metabolizável kcal/kg & $3.150,00$ & $3.150,00$ & $3.150,00$ \\
\hline Lisina Total \% & 0,85 & 0,85 & 0,84 \\
\hline Selênio Inorgânico mg/kg & 0,3 & 0,5 & 0 \\
\hline Selênio orgânico mg/kg & 0 & 0 & 0,5 \\
\hline
\end{tabular}

$85 \mathrm{mg}$ de Ferro, $50 \mathrm{mg}$ de Manganês, $283 \mathrm{mg}$ de Zinco, $95 \mathrm{mg}$ de Cobre, 0,20 $\mathrm{mg}$ de cromo, 1,4 $\mathrm{mg}$ de Iodo, $0,1760 \mathrm{mg}$ de Cobalto, $20.125 \mathrm{UI} / \mathrm{Kg}$ de Vitamina A, 5.032 UI/Kg de Vitamina D3, $210 \mathrm{mg}$ de Vitamina C,2,6838 mg de Vitamina B1, 5,1526 mg de Vitamina B2, 2,6838 $\mathrm{mg}$ de Vitamina B6, 33,55 mcg de Vitamina B12, $144 \mathrm{mg}$ de Vitamina E, 17,44 mg de Ácido Pantotenico, 4,42 mg de Vitamina K3, 1,9322 mg de Ácido Fólico, $600 \mathrm{mg}$ de Colina, 0,20 mg de Biotina, 26,1640 mg de Niacina.

Durante o período de condicionamento (pré-experimento) efetuou-se duas coletas de amostra de ração, plasma sangüíneo e seminal para mensurar a quantidade de selênio antes do início da administração dos tratamentos. A figura 5 representa a linha do tempo utilizada para as coletas das amostras de sêmen e sangue. 


\section{EXPERIMENTO}

\section{PRÉ-EXPERIMENTO}

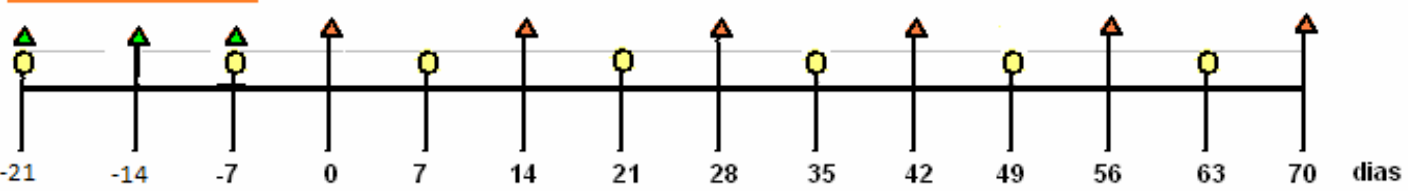

$\triangle$ Coletas de sêmen para distribuição dos animais nos tratamentos.

$\triangle$ Coletas de sêmen para avaliação das características seminais.

Coletas de amostras de plasma sangüíneo e seminal para avaliar a biodisponibilidade do selênio.

Figura 5 - Esquema experimental de coleta de amostras para avaliação das características seminais e da biodisponibilidade do selênio

No período experimental foram realizadas 6 coletas de plasma sangüíneo e seminal para determinar a concentração do selênio. As amostras foram encaminhadas ao Laboratório de Minerais da Faculdade de Zootecnia e Engenharia de Alimentos da Universidade de São Paulo, Campus Pirassununga, para averiguação da biodisponibilidade do selênio, representadas na figura 6 pelas semanas ímpares (S-7, S1, S3, S5, S7e S9). E foram realizadas seis coletas de sêmen, representadas pelas semanas pares (S0, S2, S4, S6, S8 e S10) para analisar as características seminais. A partir de cada ejaculado in natura foram preparadas as doses inseminantes na concentração final de 3 × $10^{9}$ espermatozóides para posterior avaliação do sêmen refrigerado nos períodos 0, 24, 48 e 72 horas após a diluição (Figura 6). 

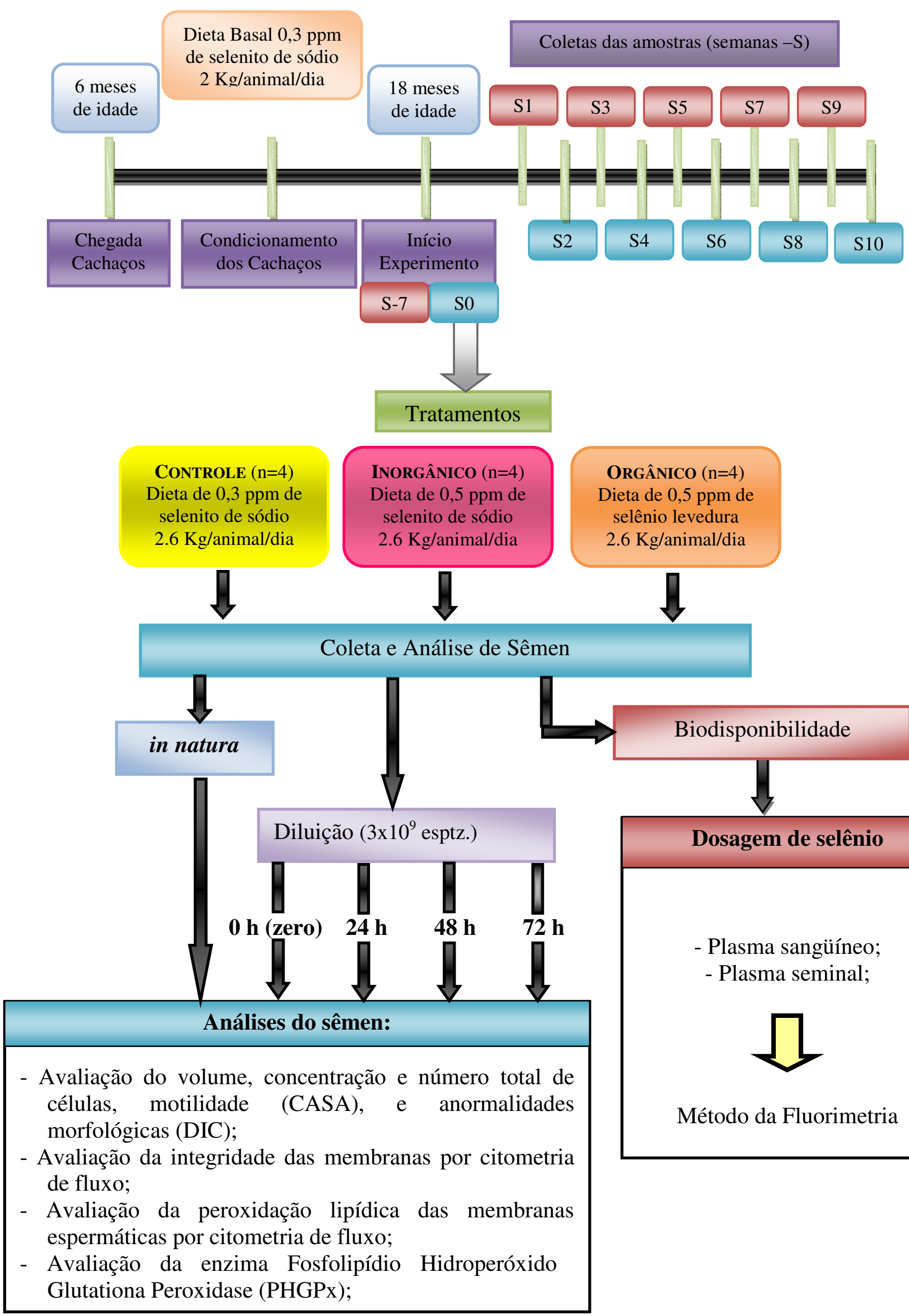

Figura 6 - Esquema experimental das análises das amostras 


\subsection{COLETA E AVALIAÇÕES ESPERMÁTICAS}

As coletas de sêmen empregaram o método da mão enluvada, com prévia higienização do prepúcio (KING; MACPHETERSON, 1973). Utilizou-se um becker previamente aquecido a $37^{\circ} \mathrm{C}$, adaptado com papel filtro, de modo a separar a fração gelatinosa da fração líquida do ejaculado (Figura 7).

Em seguida, o sêmen in natura e refrigerado $(0,24,48$ e 72 horas após a diluição com Prolimax ${ }^{\circledR}$, Vet life, a $37^{\circ} \mathrm{C}$ ) foram avaliados quanto às características da motilidade usando o aparelho Hamilton Thorne Research Motility Analyser (HTM-IVOS, Version 12.3, Hamilton Thorn Research, Beverly, Massachusetts, USA), de acordo com a metodologia descrita por Arruda (2000) e submetidos aos protocolos de coloração para a análise das integridades de membranas acrossomal e plasmática, potencial de membrana mitocondrial e peroxidação lipídica das membranas espermáticas por citometria de fluxo (conforme descrito nos itens 5.7, 5.8 e 5.9). Além destas análises, também foram realizadas: (a) mensuração do volume no próprio frasco coletor; (b) concentração espermática, contagem realizada na câmara de Neubauer na diluição 1:100; (c) anormalidades morfológicas por meio do microscópio de contraste de interferência diferencial (DIC).
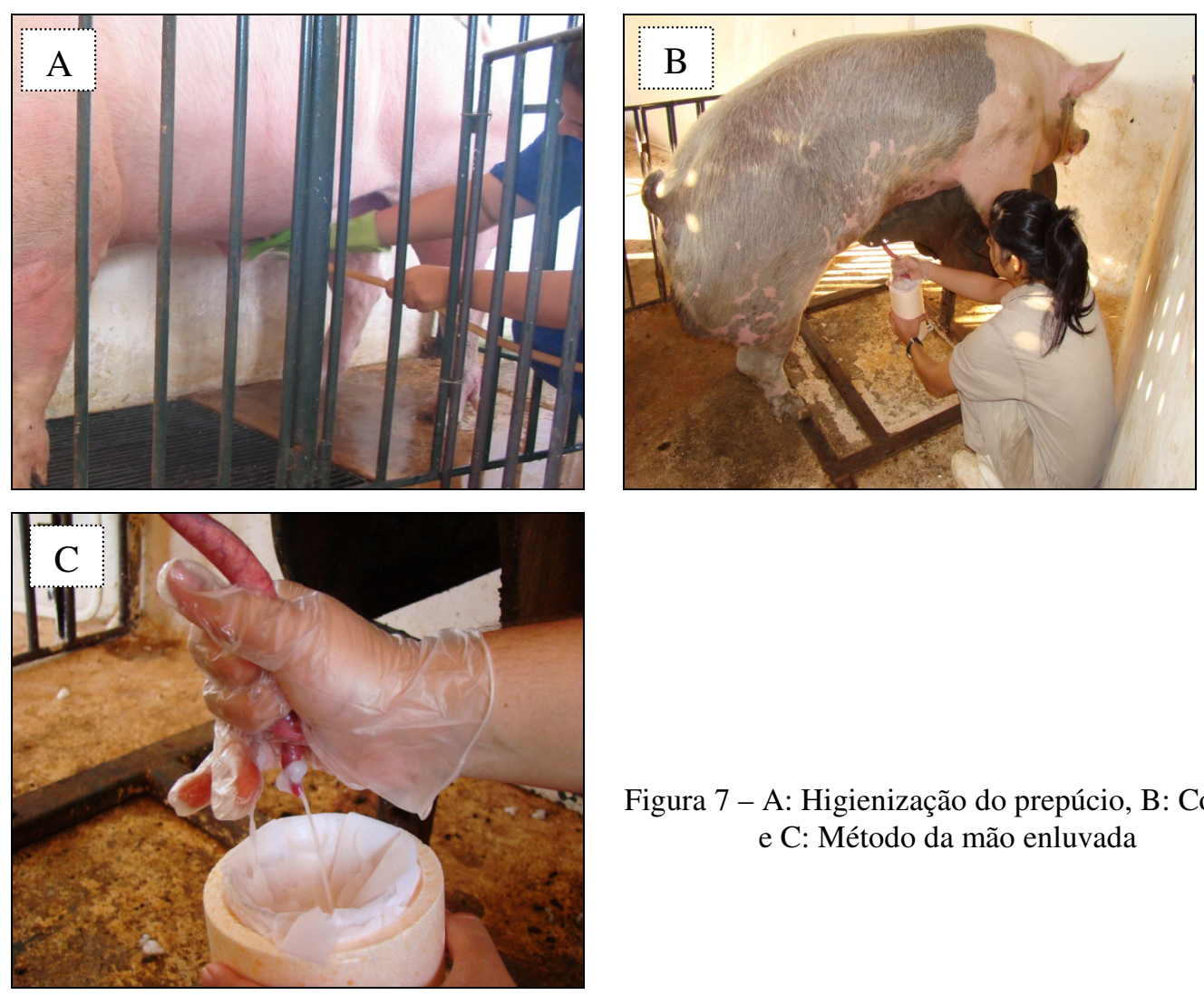

Figura 7 - A: Higienização do prepúcio, B: Coleta de sêmen e C: Método da mão enluvada 


\subsection{AVALIAÇÃO DO VOLUME E CONCENTRAÇÃO ESPERMÁTICA}

O volume do ejaculado foi mensurado no próprio becker utilizado na coleta do sêmen, após a retirada do papel filtro contendo a fração gelatinosa.

O procedimento para a contagem de espermatozóides através da câmara de Neubauer iniciou-se pela preparação de um tubo de microcentrifugação com $990 \mathrm{~mL}$ de solução formolsalino (5\%) e $10 \mu \mathrm{L}$ de sêmen, numa diluição 1:100. O resultado foi expresso em número de células espermáticas $/ \mathrm{mL}$.

\subsection{AVALIAÇÃO COMPUTADORIZADA DAS CARACTERÍSTICAS DA MOTILIDADE}

Com a finalidade de examinar a motilidade dos espermatozóides antes e após a refrigeração, e nos diferentes tratamentos, as amostras foram examinadas pelo sistema de análise computadorizada do sêmen (CASA) usando o aparelho Hamilton Thorne Research Motility Analyser (HTM-IVOS, Versão 12.3, Hamilton Thorn Research, Beverly, Massachusetts, USA, Figura 8), sendo que para a análise do movimento espermático utilizouse o programa Animal Motility. Foram previamente realizados ajustes (set up) no equipamento para a análise do sêmen suíno (Anexo A) e escolha manual do campo de leitura e análise, sendo selecionados no mínimo 5 campos por amostra. As características analisadas foram: motilidade total (\%), motilidade progressiva (\%), velocidade de trajeto (VAP, $\mu \mathrm{m} / \mathrm{s}$ ), velocidade progressiva (VSL, $\mu \mathrm{m} / \mathrm{s}$ ), velocidade curvilinear (VCL, $\mu \mathrm{m} / \mathrm{s}$ ), amplitude do deslocamento lateral da cabeça $(\mathrm{ALH}, \mu \mathrm{m})$, freqüência de batimento $(\mathrm{BCF}, \mathrm{Hz})$, retilinearidade (STR, \%) e linearidade (LIN, \%); cujas definições foram descritas por Arruda (2000). 


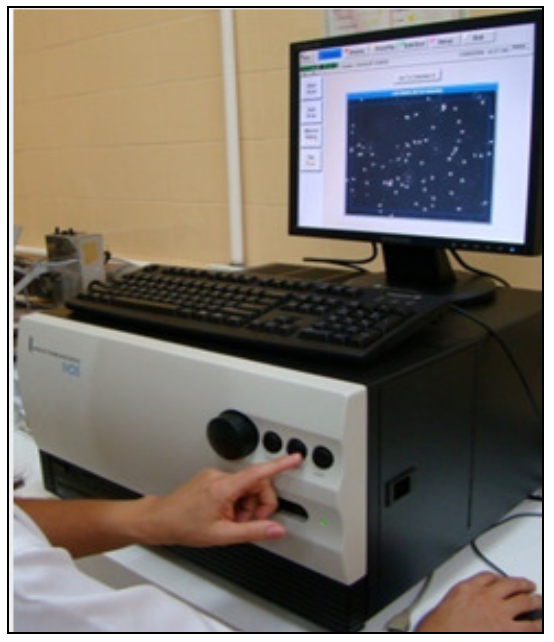

Figura 8 - HTM-IVOS, Versão 12.3, Hamilton Thorn Research, Beverly, Massachussetts, USA.

\subsection{AVALIAÇÃO DA INTEGRIDADE DAS MEMBRANAS PLASMÁTICA E ACROSSOMAL POR CITOMETRIA DE FLUXO}

Após a avaliação da concentração e da motilidade espermática, uma alíquota foi retirada das amostras de sêmen e diluídas em solução de sais de TALPm (Anexo B1) em tubos de microcentrifugação $(1,5 \mathrm{~mL})$, pré-aquecidos a $37^{\circ} \mathrm{C}$. Deste modo, as amostras foram padronizadas com uma concentração de $25 \times 10^{6}$ espermatozóides por mL. A seguir, $3 \mu \mathrm{L}$ de Iodeto de Propídio (PI, L0770, Sigma-Aldrich Co., Saint Louis, Missouri, EUA) foram adicionados as amostras conjuntamente com $50 \mu \mathrm{L}$ de Pisum Sativum Aglutinina Conjugada a uma fluoresceína (FITC-PSA, 08423HI, Sigma-Aldrich Co., Saint Louis, Missouri, EUA) (CELEGHINI et al., 2007; DE ANDRADE et al., 2007). Após 10 minutos de incubação em temperatura ambiente, os espermatozóides foram rediluídos com a adição de $600 \mu \mathrm{L}$ de TALPm e transferidos para tubos tipo falcon graduados até $15 \mathrm{~mL}\left(37^{\circ} \mathrm{C}\right)$. Com isso, as amostras apresentaram uma concentração de $5 \times 10^{6}$ espermatozóides por mL no momento de serem analisadas pela técnica de citometria de fluxo. Foram analisadas 10.000 células por amostra. 


\subsection{AVALIAÇÃO DO POTENCIAL DE MEMBRANA MITOCONDRIAL POR CITOMETRIA DE FLUXO}

Uma alíquota foi retirada das amostras e diluídas em solução de sais de TALPm (Anexo B1) em tubos de microcentrifugação $(1,5 \mathrm{~mL})$, pré-aquecidos a $37^{\circ} \mathrm{C}$. Deste modo, as amostras foram padronizadas com concentração de $25 \times 10^{6}$ espermatozóides por mL. A seguir, $6 \mu \mathrm{L}$ de JC-1 (153 $\mu \mathrm{M}$ em DMSO) foram adicionados às amostras (CELEGHINI et al., 2007; DE ANDRADE et al., 2007). Após 10 minutos de incubação em temperatura ambiente, os espermatozóides foram rediluídos com a adição de $600 \mu \mathrm{L}$ de TALPm e transferidos para tubos tipo falcon graduados até $15 \mathrm{~mL}\left(37^{\circ} \mathrm{C}\right)$. Com isso, as amostras apresentaram uma concentração de $5 \times 10^{6}$ espermatozóides por $\mathrm{mL}$ no momento de serem analisadas pela técnica de citometria de fluxo. Foram analisadas 10.000 células por amostra.

\subsection{AVALIAÇÃO DA PEROXIDAÇÃO DAS MEMBRANAS ESPERMÁTICAS POR CITOMETRIA DE FLUXO}

A análise da peroxidação das membranas espermáticas in situ foi realizada como o descrito por Raphael et al. (2008).

Foram retiradas alíquotas de sêmen durante as etapas de análise, a fim de obter amostras diluídas em TALPm (Anexo B1) com $5 \times 10^{6}$ espermatozóides/mL e com um volume final de 499,5 $\mu \mathrm{L}$. Estas foram então coradas com $0,5 \mu \mathrm{L}$ da sonda $\mathrm{C} 11$ BODIPY $^{581 / 591}(1 \mathrm{mg} / \mathrm{mL}$, D-3861, Molecular Probes Inc., Eugene, Oregon, EUA) por 30 minutos a $37^{\circ} \mathrm{C}$. Passado o período de incubação, foi transferida para outro microtubo $145 \mu \mathrm{L}$ desta solução, corada com a sonda C11-BODIPY ${ }^{581 / 591}$. Foi adicionado a amostra $3 \mu \mathrm{L}$ de Iodeto de Propídio (0,5 mg/mL, L0770, Sigma-Aldrich Co., Saint Louis, Missouri, EUA) a fim de servir como um marcador das células com membrana plasmática lesada. Após 5 minutos de incubação a $37^{\circ} \mathrm{C}$, os espermatozóides foram diluídos com a adição de $150 \mu \mathrm{L}$ de TALPm e transferidos para tubos graduados de $15 \mathrm{~mL}\left(37^{\circ} \mathrm{C}\right)$. Com isso, as amostras apresentavam uma concentração de $2,5 \times 10^{6}$ espermatozóides por mL no momento de serem 
analisadas por citometria de fluxo. Foram analisadas 10.000 células por amostra. As células viáveis (IP negativo) e coradas com a sonda C11-BODIPY ${ }^{581 / 591}$ foram analisadas quanto à média da emissão de fluorescência captada no fotomultiplicador com long pass de 502 e band pass de $530 \pm 15 \mathrm{~nm}$, esta faixa captada corresponde às células que estão sofrendo ação da peroxidação.

\subsection{ANORMALIDADES MORFOLÓGICAS}

As avaliações das anormalidades morfológicas foram realizadas utilizando-se o sêmen in natura e nos diferentes tempos de refrigeração 0 e 72 horas após a diluição. $\mathrm{O}$ sêmen foi diluído e fixado em formol salino tamponado. Cada amostra de sêmen foi avaliada utilizandose a técnica da câmara úmida, sendo que uma gota do sêmen diluído foi depositada sobre lâmina, coberta por lamínula e analisada em microscópio de contraste de interferência diferencial (DIC) com aumento de 1000 vezes sob óleo de imersão, avaliando-se 200 espermatozóides (Figura 9). As anormalidades morfológicas foram agrupadas em 7 categorias: normais, defeitos de acrossoma, defeitos de cabeça, defeitos de colo, defeitos de peça intermediária, defeitos de cauda e gota protoplasmática proximal (CBRA, 1998).

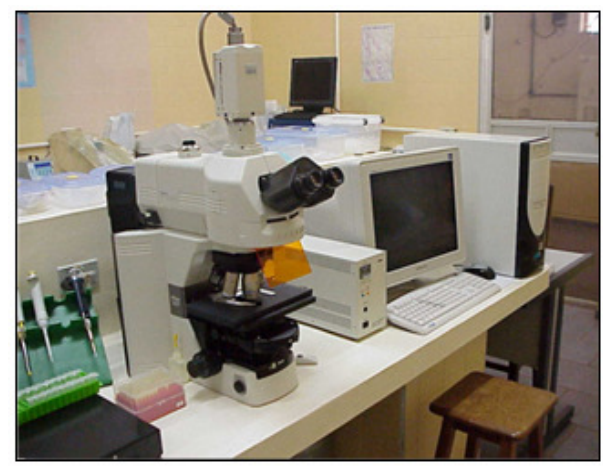

Figura 9 - Microscópio de Contraste de Interferência Diferencial (DIC) 


\subsection{AVALIAÇÃO DO NÚMERO TOTAL DE ESPERMATOZÓIDES DO EJACULADO E NÚMERO DE DOSES INSEMINANTES}

O número total de espermatozóides do ejaculado foi obtido através da multiplicação do volume (mL) pela concentração espermática (x $10^{6}$ espermatozóides $\left./ \mathrm{mL}\right)$.

Em relação ao número de doses inseminantes produzidas por ejaculado, o cálculo utilizado foi a multiplicação do número total de espermatozóides pela motilidade. O resultado obtido foi dividido por $3 \times 10^{9}$ espermatozóides, quantidade de células presentes na dose inseminante (CORRÊA et al., 2001).

\subsection{AVALIAÇÃO DA ATIVIDADE DA ENZIMA FOSFOLIPÍDIO HIDROPERÓXIDO GLUTATIONA PEROXIDASE (PHGPX)}

Após a análise do sêmen e a preparação das doses inseminantes $\left(3 \times 10^{9}\right.$ espermatozóides), foram retirados aproximadamente $50 \mathrm{~mL}$ de sêmen in natura para a preparação das amostras. O ejaculado foi inicialmente centrifugado a 600 x g por 10 minutos a $4^{\circ}$ C.e o sobrenadante retirado. Os espermatozóides foram lavados com duas centrifugações consecutivas a $600 \mathrm{x}$ g por 10 minutos a $4^{\circ} \mathrm{C}$, em tampão fosfato salino (PBS) (Anexo C1) e suspensos à concentração final de $700 \times 10^{6}$ espermatozóides/mL, sendo armazenados em tubos criogênicos no freezer $-80^{\circ} \mathrm{C}$ no Laboratório de Biotecnologia do Sêmen e Andrologia (LBSA-FMVZ/USP).

As amostras foram levadas ao Laboratório de Química Biológica (LQB-FZEA/USP) descongeladas e uma alíquota de $250 \mu \mathrm{L}$ foi centrifugada a $600 \mathrm{x}$ g por 10 minutos a $4^{\circ} \mathrm{C}$. O sobrenadante foi desprezado e o pellet suspenso em $500 \mu \mathrm{L}$ de tampão de lise (Tris-HCl; Trishidroximetilaminometano-Ácido Clorídrico $0,1 \mathrm{M}$, guanidina- $\mathrm{HCl} 6 \mathrm{~mol} / \mathrm{L}$, pepstatina A 0,5 $\mu \mathrm{g} / \mathrm{mL}$, e 2-mercaptoetanol 0,1 M, pH 7,4, Anexo C2). Após 5 minutos foi realizada a passagem da amostra por doze vezes através de uma agulha 45 x 13 mm. Foram adicionados mais $500 \mu \mathrm{L}$ de tampão de lise e as amostras foram homogeneizadas por trinta minutos no 
vórtex, divididos em 2 minutos em agitação e 4 minutos em descanso. As amostras foram mantidas em gelo durante todo o procedimento.

Após a homogeneização, as amostras foram novamente centrifugadas a $20000 \mathrm{x} \mathrm{g}$ por 30 minutos a $4^{\circ} \mathrm{C}$.

O conteúdo de proteína das amostras foi determinado pelo método de Bradford (BRADFORD, 1976) e estas foram diluídas com tampão de lise à concentração final de 1 $\mathrm{mg} / \mathrm{mL}$.

Antes da determinação da atividade da PHGPx, a guanidina-HCl e o mercaptoetanol foram removidos pela passagem da amostra duas vezes através de uma coluna NAP-10. Aplicou-se $1 \mathrm{~mL}$ da amostra na coluna NAP-10, previamente equilibrada com $5 \mathrm{~mL}$ de tampão Tris-HCl (0,1 M pH7,4, Anexo C3) e 15 mL de tampão de eluição (0,1 M Tris-HCl, pH 7,5, contendo $3 \mathrm{mM}$ glutationa reduzida - GSH, $5 \mathrm{mM}$ EDTA-Ácido Etileno Diamino Tetracético; e 0,1\% [vol/vol] Triton X-100, Anexo C4). A amostra resultante desse processo foi centrifugada a $15000 \mathrm{xg}$ por 15 minutos a $4^{\circ} \mathrm{C}$ e o sobrenadante foi utilizado para a mensuração da enzima.

A atividade da PHGPx foi mensurada em cubeta de quartzo e o volume final do ensaio foi de $1 \mathrm{~mL}$.

O ensaio foi realizado em tampão de reação $0,1 \mathrm{M}$ Tris- $\mathrm{HCl}, \mathrm{pH}$ 7,4 contendo $5 \mathrm{mM}$ EDTA, $1 \mathrm{mM}$ azida de sódio $\left(\mathrm{NaN}_{3}\right)$ (Anexo C5), 1,2 UI/mL glutationa redutase (GR), 0,12\% [vol/vol] Triton X-100, 0,2 mM Nicotinamida Adenina Di-nucleotídio Fosfato (NADPH), 3 $\mathrm{mM}$ glutationa reduzida (GSH) e amostra. A mistura foi incubada por 3 minutos a $37^{\circ} \mathrm{C}$ e após a determinação da taxa basal de oxidação do NADPH, a reação foi iniciada pela adição do substrato hidroperóxido de fosfatidilcolina $15 \mu \mathrm{M}$. Simultaneamente foi realizado um branco contendo todos os reagentes, exceto o substrato.

A leitura foi realizada em espectrofotômetro (Beckman DU 800) a $340 \mathrm{~nm}$ e $37^{\circ} \mathrm{C}$ (Figura 10). A atividade enzimática foi calculada subtraindo do delta da amostra o delta do branco e expressa em miliunidades mU/mg de proteína (MAIORINO; GREGOLIN; URSINI, 1990; GAROLLA et al.,2005), com algumas adaptações.

O hidroperóxido de fosfatidilcolina foi utilizado como substrato para a mensuração da enzima PHGPx (Anexo C6), sendo relatado por Maiorino; Gregolin; Ursini (1990) e Roveri; Maiorino; Ursini (1994) que somente a enzima PHGPx é ativa para este substrato. 


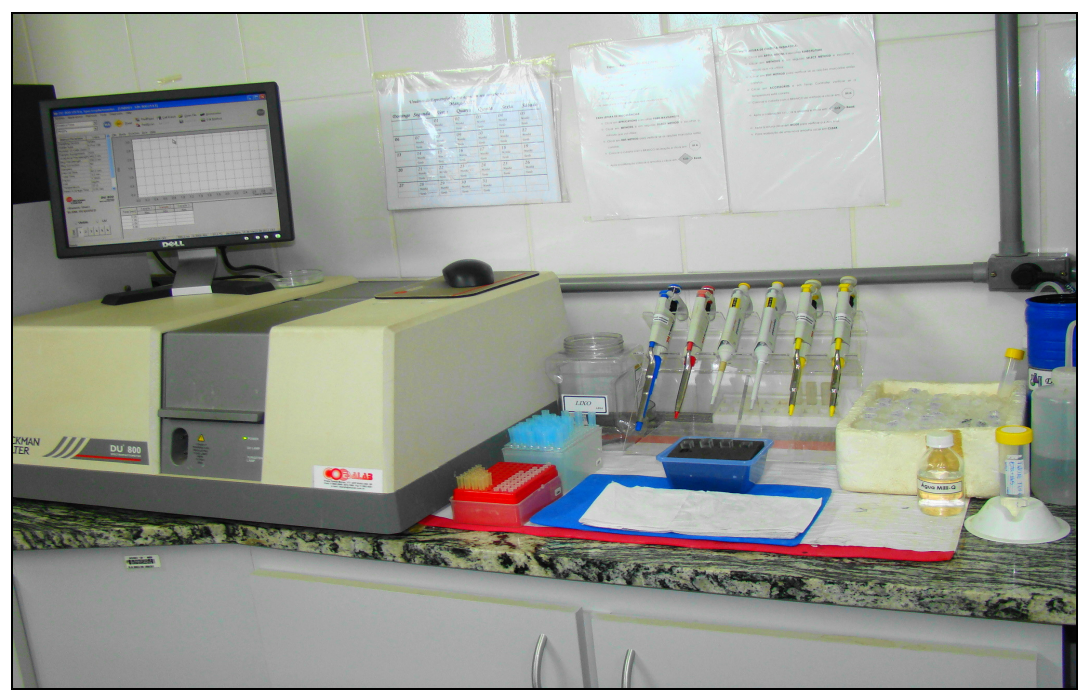

Figura 10 - Espectrofotômetro Beckman DU 800

\subsection{ANÁLISE DA BIODISPONIBILIDADE DO SELÊNIO}

Durante o pré-experimento foram efetuadas 2 coletas com intervalo semanal de plasma sangüíneo e seminal para mensuração da quantidade de selênio antes do início da administração dos tratamentos. Depois no período experimental foram colhidas 5 amostras (plasma sangüíneo e seminal) para análise do selênio e encaminhadas ao Laboratório de Minerais da Faculdade de Zootecnia e Engenharia de Alimentos da Universidade de São Paulo, Campus Pirassununga, para averiguação da concentração do selênio, orgânico e inorgânico.

As amostras de ração foram coletadas para determinar a concentração de selênio presente nas 3 dietas experimentais. As amostras de sêmen foram coletadas pelo método da mão enluvada e as amostras de sangue $(10 \mathrm{~mL})$ foram coletadas em tubos heparinizados, por punção na veia jugular (Figura 11) e centrifugados a 2.500 x g por 15 minutos para obtenção de aproximadamente $5 \mathrm{~mL}$ de plasma sangüíneo. Posteriormente, o plasma foi armazenado em tubos criogênicos no freezer a $-20^{\circ} \mathrm{C}$ e encaminhado ao laboratório para análise. 


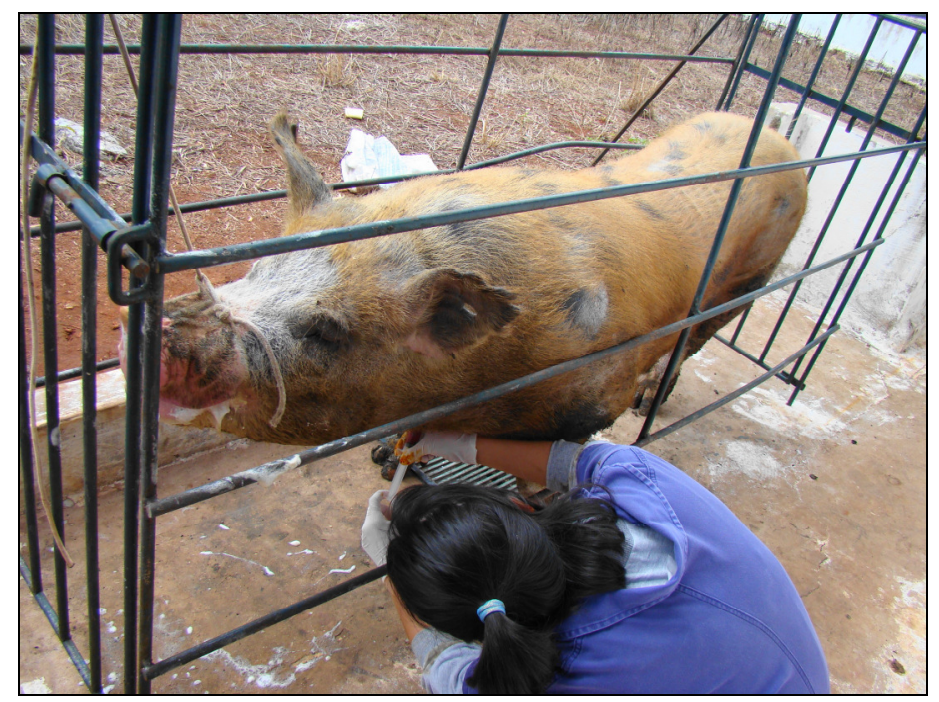

Figura 11 - Coleta de sangue por punção da veia jugular

O selênio foi analisado utilizando-se $0,5 \mathrm{~g}$ de amostras de ração e $2 \mathrm{~mL}$ de plasma sangüíneo e seminal. Foram adicionados $5 \mathrm{~mL}$ de $\mathrm{HNO}_{3}$ e $3 \mathrm{~mL}$ de $\mathrm{HClO}_{3}$, e encaminhado para o bloco digestor até atingir $210^{\circ} \mathrm{C}$. Após o resfriamento da solução foi adicionado $2,5 \mathrm{~mL}$ de $\mathrm{HCl}$ 1:9, permanecendo em banho-maria com água fervente por 30 minutos. Depois de resfriado, adicionou-se $5 \mathrm{~mL}$ de cloridrato de hidroxilamina e 3 gotas de cresol vermelho. $\mathrm{O}$ $\mathrm{pH}$ foi previamente regulado utilizando $\mathrm{HCl} \mathrm{1:4} \mathrm{e} \mathrm{NH}_{3}$ 1:1 até a coloração salmão (pH 0,5). Posteriormente adicionou-se $5 \mathrm{~mL}$ de DAN (2-3 Diaminonaftaleno), sendo levado ao banhomaria $\left(80^{\circ} \mathrm{C}\right)$ por 30 minutos (no escuro) e após o resfriamento foi adicionado $10 \mathrm{~mL}$ de ciclohexano. Posteriormente, realizou-se uma cuidadosa agitação, e o sobrenadante foi coletado. O selênio foi determinado pelo método de fluorimetria (OLSON; PALMER; CARY, 1975).

\subsection{ANÁLISE ESTATÍSTICA}

Os dados obtidos do experimento foram analisados com prévia verificação da normalidade dos resíduos e da homogeneidade das variâncias. As variáveis dependentes não atenderam às premissas estatísticas, então foram submetidas à transformação em arco-seno ou em logaritmo. Os dados transformados foram submetidos à análise de variância (PROC GLM), empregando-se o programa SAS (1999). Às análises estatísticas destas variáveis foram 
ainda adicionadas do fator medidas repetidas no tempo, referentes aos momentos de amostragem (parte 1 - referente às seis coletas realizadas durante a suplementação; parte 2 referente aos 4 períodos em que o sêmen diluído e armazenado foi analisado).

As probabilidades de interações com o tempo foram determinadas pelo teste de Greenhouse-Geisse, utilizando-se o comando REPEATED gerado pelo procedimento GLM (PROC GLM do SAS). As variáveis analisadas não apresentaram interação entre os tempos de amostragem e o tratamento $(\mathrm{P}>0,05)$. Deste modo, realizou-se a análise dos efeitos principais. As análises para efeito de tempo foram realizadas pelo teste de Fisher (LSD) e o efeito do tratamento pela análise por contraste ortogonal, sendo o contraste 1 (C1) efeito da suplementação (0,3 x 0,5 ppm de selênio) e contraste 2 (C2) efeito da fonte (orgânica x inorgânica). As hipóteses testadas foram consideradas significativas quando $P<0,05$. As possíveis correlações foram analisadas pelo teste de correlação linear de Pearson considerando-se o nível de $5 \%$ de significância. Os dados das tabelas foram apresentados na forma não transformada em arco-seno ou em logaritmo.

As tabelas da análise de variância foram apresentadas no Anexo D, sendo a análise do efeito do tratamento em função do tempo (Anexo D1) e o efeito do tratamento em função do período de armazenamento do sêmen refrigerado suíno (Anexo D2). 


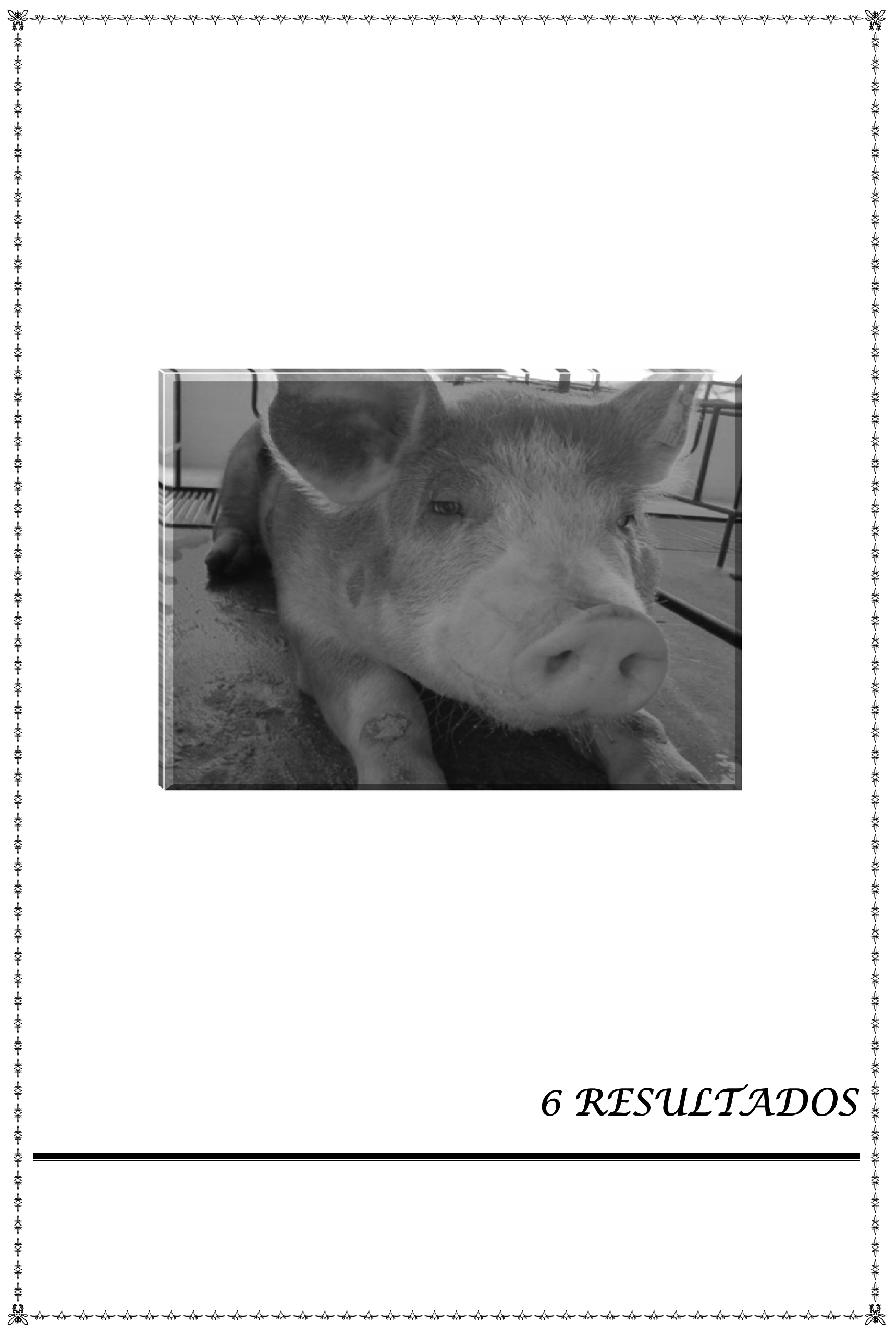




\section{RESULTADOS}

Os resultados estão apresentados em duas partes. A parte 1 avaliou o efeito da suplementação oral de selênio levedura sobre o movimento espermático, as anormalidades morfológicas e integridade das membranas plasmática, acrossomal e mitocondrial e peroxidação lipídica das membranas espermáticas, bem como a atividade da enzima fosfolipídio hidroperóxido glutationa peroxidase (PHGPx). Além destas também foram averiguadas características pertinentes ao sêmen in natura como o volume, a concentração, o número total de células e o número de doses inseminantes durante as 11 semanas de suplementação. As coletas foram realizadas quinzenalmente, totalizando 6 coletas por tratamento.

$\mathrm{Na}$ parte 2 investigou-se o efeito da suplementação oral de selênio levedura nas mesmas características citadas anteriormente, no sêmen refrigerado a $18^{\circ} \mathrm{C}$ nos períodos 0 , 24, 48 e 72 horas após a diluição.

\subsection{PARTE 1: EFEITO DA SUPLEMENTAÇÃO ORAL DE SELÊNIO SOBRE AS CARACTERÍSTICAS DO SÊMEN IN NATURA DE CACHAÇOS}

Neste tópico estão apresentados os resultados do efeito do selênio nas características do sêmen in natura de cachaços.

\subsubsection{EFEITO DO SELÊNIO NO VOLUME, CONCENTRAÇÃO, NÚMERO TOTAL DE CÉLULAS E NÚMERO DE DOSES INSEMINANTES NO SÊMEN IN NATURA}

Não houve interação significativa entre tratamento e semana nas características volume, concentração, número total de células e número de doses inseminantes. $\mathrm{O}$ volume do ejaculado dos cachaços não foi influenciado pela suplementação $(297,29$ vs. $321,66 \mathrm{~mL}, 0,3$ vs. 0,5 ppm de selênio, respectivamente) e pelo tipo de fonte de selênio (308,33 vs. $335 \mathrm{~mL}$, 
inorgânico vs. orgânico, respectivamente), sendo verificado efeito de semana $(p<0,05)$ com uma ligeira queda para todos os tratamentos (Tabela 2). $\mathrm{O}$ tratamento orgânico iniciou a pesquisa com um volume superior em 116,25 e $105 \mathrm{~mL}$ em comparação ao controle e inorgânico, respectivamente (Tabela 3). E apresentou a maior redução do grupo entre as semanas zero e dois e os demais tratamentos só apresentaram queda no intervalo entre a quarta e a sexta semana. De modo geral, esta característica se manteve estável até a quarta semana com posterior redução no volume do ejaculado $(\mathrm{p}<0,05)$ nas semanas subseqüentes.

Os animais que receberam o tratamento orgânico apresentaram maior concentração espermática $(\mathrm{p}<0,05)$ em relação ao grupo inorgânico $\left(267,29\right.$ vs. $211,27 \times 10^{6}$ espermatozóides/mL, respectivamente), não sendo observada diferença entre a suplementação ou não selênio na dieta (239,28 vs. 208,24 x $10^{6}$ espermatozóides/mL, respectivamente). Verificou-se uma diminuição nesta característica em todos os tratamentos, entre a segunda e a quarta semana, sendo observado nas semanas posteriores concentrações mais elevadas, exceto para o grupo controle na oitava semana.

Tabela 2 - Médias e desvios-padrão das características do sêmen in natura de cachaços durante 77 dias

\begin{tabular}{|c|c|c|c|c|c|c|c|c|}
\hline \multirow{4}{*}{$\begin{array}{c}\text { Características } \\
\text { Seminais }\end{array}$} & \multicolumn{8}{|c|}{ Sêmen in natura } \\
\hline & \multicolumn{3}{|c|}{ Tratamentos (ppm) } & \multirow{3}{*}{ DP } & \multicolumn{4}{|c|}{ Probabilidade } \\
\hline & \multicolumn{2}{|c|}{$\begin{array}{c}\text { Selênio } \\
\text { Inorgânico }\end{array}$} & \multirow{2}{*}{$\begin{array}{c}\text { Selênio } \\
\text { Orgânico }\end{array}$} & & \multicolumn{2}{|c|}{ Tratamento } & \multirow[t]{2}{*}{$\mathrm{S}$} & \multirow[t]{2}{*}{$\mathrm{T}^{*} \mathrm{~S}$} \\
\hline & 0,3 & 0,5 & & & $\mathrm{C} 1$ & $\mathrm{C} 2$ & & \\
\hline VOL & 297,29 & 308,33 & 335,00 & 98,59 & 0,3267 & 0,3526 & 0,0197 & 0,7777 \\
\hline CONC & 208,44 & 211,27 & 267,29 & 95,51 & 0,1883 & 0,0403 & 0,0562 & 0,8390 \\
\hline $\mathrm{N}^{\circ}$ TOTAL & 56,58 & 61,61 & 83,26 & 27,02 & 0,0125 & 0,0034 & 0,4286 & 0,9980 \\
\hline $\mathrm{N}^{\circ}$ DOSES & 17,12 & 18,60 & 25,34 & 8,52 & 0,0156 & 0,0040 & 0,3121 & 0,9991 \\
\hline
\end{tabular}

C1 (Contraste 1) = 0,3 ppm vs. 0,5 ppm Selênio; C2 (Contraste 2) = 0,5 ppm de Selênio inorgânico vs. 0,5 ppm de Selênio orgânico; $\mathrm{S}$ - semana; $\mathrm{T} * \mathrm{~S}$ - interação tratamento e semana

VOL - Volume (mL); CONC - Concentração espermática (x $10^{6}$ esptz./mL); $\mathrm{N}^{\circ}$ TOTAL - número total de células (x $10^{9}$ esptz.); DP - desvio-padrão.

Ao se analisar o número total de células, verificou-se que os grupos que receberam a suplementação de selênio, independentemente da fonte apresentaram valores superiores ao 
grupo não suplementado $(\mathrm{p}<0,05)$. E entre as fontes suplementadas, a orgânica mostrou valor superior a inorgânica $(\mathrm{p}<0,05)$, sendo a diferença de 21,65 x $10^{9}$ espermatozóides.

Ao se calcular o número de doses inseminantes que estes cachaços foram capazes de produzir constatou-se novamente efeito da suplementação $(\mathrm{p}<0,05)$, sendo que em ambos os grupos suplementados os valores foram superiores ao encontrado para o grupo controle e também verificou-se efeito significativo de fonte $(\mathrm{p}<0,05)$ (Tabela 2$)$. O selênio orgânico propiciou um aumento na concentração espermática, que por sua vez levou ao maior número total de células e conseqüentemente ao maior número de doses.

Vale ressaltar, que os cachaços do tratamento orgânico produziram 8,22 e 6,74 doses a mais em comparação ao controle e inorgânico, respectivamente. Se considerarmos que para cada fêmea inseminada são utilizadas 3 doses inseminantes, as doses produzidas pelos cachaços do grupo orgânico seriam responsáveis pela inseminação de 8 fêmeas, o inorgânico por 6 fêmeas e o controle por 5 fêmeas.

O número de doses nas 6 semanas analisadas foi maior para o grupo orgânico, não havendo consideráveis diferenças entre os tratamentos. 
Tabela 3 - Médias \pm desvios-padrão das características do sêmen in natura de cachaços em intervalos de 14 dias

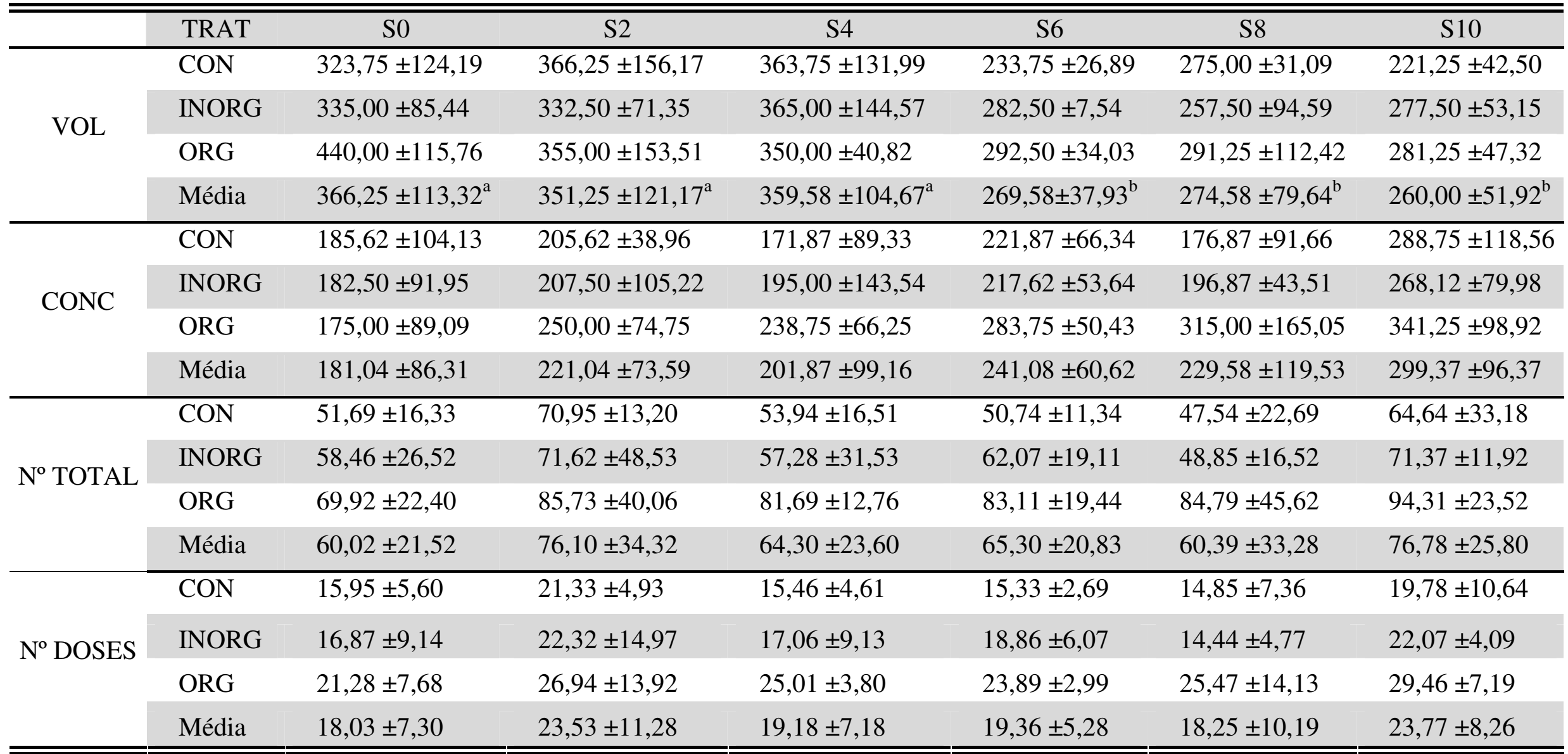

TRAT - Tratamentos; CON - Controle; INORG - Inorgânico; ORG - Orgânico; S - Semana; VOL - Volume (mL); CONC - Concentração espermática (x 106 esptz./mL); $\mathrm{N}^{\mathrm{o}}$ TOTAL - número total de células (x $10^{9}$ esptz.); DP - desvio-padrão.

${ }^{a, b}$ Letras minúsculas diferentes na mesma linha, diferem estatisticamente $\mathrm{p}<0,05$ (teste LSD). 


\subsubsection{EFEITO DO SELÊNIO NA INTEGRIDADE DA MEMBRANA PLASMÁtiCA E ACROSSOMAL,} POTENCIAL DE MEMBRANA MITOCONDRIAL E PEROXIDAÇÃO DAS MEMBRANAS NO SÊMEN IN NATURA

Nestas características não foram detectadas interações significativas entre as semanas e os tratamentos $(p>0,05)$. A dieta fornecida aos cachaços não interferiu na integridade das membranas acrossomal e plasmática, assim como não aumentou o potencial de membrana mitocondrial e também não reduziu a peroxidação lipídica das membranas espermáticas no sêmen in natura, independentemente da suplementação ou da fonte de selênio utilizada (Tabela 4).

Tabela 4 - Médias e desvios-padrão de integridade da membrana plasmática e acrossomal, potencial mitocondrial e peroxidação de membrana no sêmen in natura de cachaços durante 77 dias

\begin{tabular}{|c|c|c|c|c|c|c|c|c|}
\hline \multirow{4}{*}{$\begin{array}{c}\text { Características } \\
\text { Espermáticas }\end{array}$} & \multicolumn{8}{|c|}{ Sêmen in natura } \\
\hline & \multicolumn{3}{|c|}{ Tratamentos (ppm) } & \multicolumn{5}{|c|}{ Probabilidade } \\
\hline & \multicolumn{2}{|c|}{$\begin{array}{c}\text { Selênio } \\
\text { Inorgânico }\end{array}$} & \multirow{2}{*}{$\begin{array}{c}\begin{array}{c}\text { Selênio } \\
\text { Orgânico }\end{array} \\
0,5\end{array}$} & \multirow[t]{2}{*}{ DP } & \multicolumn{2}{|c|}{ Tratamento } & \multirow[t]{2}{*}{$S$} & \multirow[t]{2}{*}{$\mathrm{T} * \mathrm{~S}$} \\
\hline & 0,3 & 0,5 & & & $\mathrm{C} 1$ & $\mathrm{C} 2$ & & \\
\hline $\operatorname{AIMI}(\%)$ & 81,00 & 79,03 & 79,41 & 10,25 & 0,6190 & 0,8936 & 0,0962 & 0,3759 \\
\hline MAI (\%) & 83,54 & 82,33 & 82,01 & 9,32 & 0,7428 & 0,9194 & 0,3349 & 0,1638 \\
\hline MI (\%) & 90,18 & 88,55 & 87,79 & 9,33 & 0,7456 & 0,8995 & 0,1572 & 0,3383 \\
\hline $\mathrm{CP}(\%)$ & 79,79 & 78,47 & 78,72 & 11,66 & 0,6339 & 0,8491 & 0,0013 & 0,4078 \\
\hline IFMI (u.a.) & 145,50 & 142,78 & 311,67 & 541,54 & 0,4195 & 0,2764 & $<, 0001$ & 0,7502 \\
\hline
\end{tabular}

C1 (Contraste 1) = 0,3 ppm vs. 0,5 ppm Selênio; C2 (Contraste 2) = 0,5 ppm de Selênio inorgânico vs. 0,5 ppm de Selênio orgânico; $\mathrm{S}$ - semana; $T * \mathrm{~S}$ - interação tratamento e semana

AIMI - membrana plasmática e acrossomal íntegra; MAI - membrana acrossomal íntegra; MI - membrana plasmática íntegra; CP - potencial de membrana mitocondrial; IFMI - intensidade da fluorescência da população espermática com membrana plasmática íntegra.

A porcentagem de células com acrossoma e membrana plasmática íntegra foi detectada apenas uma tendência ao efeito de semana $(\mathrm{p}<0,10)$ (Tabela 4). De maneira geral, em todas as semanas esta característica se manteve relativamente constante, apresentando pequenos aumentos nos percentuais entre a zero e a décima semana, equivalentes a 6,38\%, 10,32\% e 6,03\%, no controle, inorgânico e orgânico, respectivamente (Tabela 5). 
Em relação às células com membrana acrossomal íntegra também não foi observado efeito de semana, apenas uma discreta redução nestes percentuais no grupo orgânico na sexta e oitava semana, diferentemente dos demais tratamentos que não apresentaram reduções (Tabela 5). E os resultados para as células com membrana plasmática íntegra foram semelhantes aos mencionados para a característica anterior, sendo verificada em ambas as semanas menor percentual para o grupo orgânico em comparação aos demais (Tabela 5).

Os espermatozóides foram considerados com potencial de membrana mitocondrial àqueles que no momento da análise por citometria de fluxo, pertenciam aos quadrantes de alto e médio potencial de membrana mitocondrial. Efeito de semana foi evidenciado para esta característica e também para a peroxidação lipídica das membranas $(\mathrm{p}<0,05)$ (Tabela 4). Até a segunda semana, o tratamento orgânico apresentou os menores percentuais, havendo nas semanas subseqüentes um aumento que se manteve até o final do estudo.

Em relação ao efeito de semana, a peroxidação lipídica das membranas espermáticas reduziu significativa $(\mathrm{p}<0,05)$, sendo os maiores valores observados na semana 0 (S0) seguida de discretas reduções nas semanas subseqüentes. 
Tabela 5 - Médias \pm desvios-padrão das características de integridade da membrana plasmática e acrossomal, potencial mitocondrial e peroxidação lipídica de membrana no sêmen in natura de cachaços em intervalos de 14 dias

\begin{tabular}{|c|c|c|c|c|c|c|c|}
\hline & TRAT & S0 & $\mathrm{S} 2$ & $\mathrm{~S} 4$ & S6 & $\mathrm{S} 8$ & S10 \\
\hline \multirow{4}{*}{$\begin{array}{c}\text { AIMI } \\
(\%)\end{array}$} & $\mathrm{CON}$ & $78,42 \pm 1,86$ & $77,52 \pm 2,62$ & $79,82 \pm 1,96$ & $82,47 \pm 2,68$ & $82,95 \pm 1,85$ & $84,80 \pm 2,80$ \\
\hline & INORG & $72,95 \pm 7,56$ & $75,02 \pm 11,98$ & $80,20 \pm 4,97$ & $80,37 \pm 3,22$ & $82,35 \pm 2,51$ & $83,27 \pm 3,99$ \\
\hline & ORG & $78,57 \pm 3,44$ & $81,45 \pm 6,41$ & $83,00 \pm 1,46$ & $75,17 \pm 7,76$ & $73,67 \pm 11,17$ & $84,60 \pm 3,59$ \\
\hline & Média & $76,65 \pm 9,30$ & $78,00 \pm 14,72$ & $81,00 \pm 5,97$ & $79,34 \pm 9,76$ & $79,66 \pm 12,90$ & $84,22 \pm 6,36$ \\
\hline \multirow{4}{*}{$\begin{array}{l}\text { MAI } \\
(\%)\end{array}$} & $\mathrm{CON}$ & $81,05 \pm 1,80$ & $80,62 \pm 1,96$ & $82,90 \pm 1,48$ & $85,52 \pm 2,45$ & $84,95 \pm 1,41$ & $86,17 \pm 2,44$ \\
\hline & INORG & $77,77 \pm 6,02$ & $78,05 \pm 10,90$ & $83,92 \pm 3,92$ & $84,05 \pm 3,07$ & $84,62 \pm 2,23$ & $85,55 \pm 3,92$ \\
\hline & ORG & $81,37 \pm 3,27$ & $84,60 \pm 5,24$ & $85,77 \pm 1,96$ & $79,30 \pm 6,98$ & $74,77 \pm 11,19$ & $86,25 \pm 3,20$ \\
\hline & Média & $80,06 \pm 7,59$ & $81,09 \pm 13,10$ & $84,20 \pm 4,98$ & $82,96 \pm 8,81$ & $81,45 \pm 12,98$ & $85,99 \pm 5,88$ \\
\hline \multirow{4}{*}{$\begin{array}{l}\mathrm{MI} \\
(\%)\end{array}$} & $\mathrm{CON}$ & $88,87 \pm 0,94$ & $91,27 \pm 2,61$ & $89,20 \pm 4,62$ & $88,60 \pm 4,36$ & $90,62 \pm 2,73$ & $92,47 \pm 2,02$ \\
\hline & INORG & $83,50 \pm 9,61$ & $88,65 \pm 10,25$ & $90,00 \pm 3,27$ & $87,62 \pm 2,51$ & $90,12 \pm 2,64$ & $91,40 \pm 3,34$ \\
\hline & ORG & $87,47 \pm 4,19$ & $90,90 \pm 3,60$ & $90,38 \pm 2,55$ & $84,42 \pm 13,50$ & $81,75 \pm 20,24$ & $91,82 \pm 3,32$ \\
\hline & Média & $86,62 \pm 6,0$ & $90,28 \pm 5,96$ & $89,86 \pm 3,28$ & $86,88 \pm 7,75$ & $87,50 \pm 11,57$ & $91,90 \pm 2,72$ \\
\hline \multirow{4}{*}{$\begin{array}{l}\mathrm{CP} \\
(\%)\end{array}$} & $\mathrm{CON}$ & $79,45 \pm 3,87$ & $79,45 \pm 7,31$ & $68,32 \pm 4,24$ & $89,77 \pm 3,37$ & $69,57 \pm 4,60$ & $92,20 \pm 2,12$ \\
\hline & INORG & $73,30 \pm 3,49$ & $83,22 \pm 6,35$ & $69,67 \pm 3,83$ & $88,07 \pm 1,22$ & $67,70 \pm 1,55$ & $88,82 \pm 1,90$ \\
\hline & ORG & $76,47 \pm 2,89$ & $67,10 \pm 8,71$ & $76,85 \pm 4,76$ & $88,85 \pm 2,47$ & $70,35 \pm 0,72$ & $92,72 \pm 3,06$ \\
\hline & Média & $76,41 \pm 6,76^{b, c}$ & $76,59 \pm 15,39^{b}$ & $71,61 \pm 8,69^{b, c}$ & $88,90 \pm 4,60^{a}$ & $69,21 \pm 5,26^{c}$ & $91,25 \pm 4,72^{\mathrm{a}}$ \\
\hline \multirow{4}{*}{$\begin{array}{l}\text { IFMI } \\
\text { (u.a.) }\end{array}$} & $\mathrm{CON}$ & $265,25 \pm 25,26$ & $140,00 \pm 57,94$ & $92,25 \pm 14,97$ & $135,50 \pm 18,91$ & $125,00 \pm 20,07$ & $115,00 \pm 25,88$ \\
\hline & INORG & $266,67 \pm 14,19$ & $109,75 \pm 31,60$ & $114,00 \pm 70,51$ & $162,00 \pm 73,01$ & $104,75 \pm 20,66$ & $130,50 \pm 37,54$ \\
\hline & ORG & $231,33 \pm 51,54$ & $113,25 \pm 51,82$ & $85,00 \pm 48,30$ & $117,00 \pm 52,96$ & $104,25 \pm 30,25$ & $109,75 \pm 13,65$ \\
\hline & Média & $255,50 \pm 33,56^{a}$ & $121,00 \pm 47,95^{\mathrm{b}, \mathrm{c}}$ & $97,08 \pm 47,10^{c}$ & $138,17 \pm 51,85^{b}$ & $111,33 \pm 24,03^{b, c}$ & $118,42 \pm 26,50^{b, c}$ \\
\hline
\end{tabular}

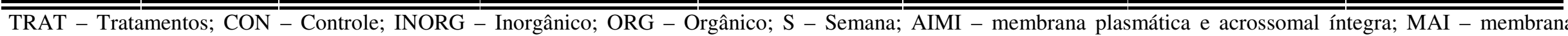
acrossomal íntegra; MI - membrana plasmática íntegra; CP - potencial de membrana mitocondrial; IFMI - intensidade da fluorescência da população espermática com membrana plasmática íntegra

${ }_{\mathrm{a}, \mathrm{b}, \mathrm{c}}$ Letras minúsculas diferentes na mesma linha, diferem estatisticamente $\mathrm{p}<0,05$ (teste LSD). 


\subsubsection{EFEITO DO SELÊNIO NAS CARACTERÍSTICAS DO MOVIMENTO ESPERMÁTICO NO SÊMEN IN} NATURA

Os resultados das propriedades cinemáticas dos espermatozóides estão descritos na tabela 6. E de maneira semelhante às características anteriores, não foram encontradas interação entre os fatores estudados.

O sêmen fresco de cachaços parece não ter sido influenciado pelo selênio recebido na dieta em relação aos percentuais de motilidade total (MT) e progressiva (MP), células rápidas (RAP), amplitude de deslocamento lateral de cabeça (ALH), retilinearidade (STR) e a linearidade $(\mathrm{LIN})$, sendo verificada diferença $(\mathrm{p}<0,05)$ na freqüência de batimentos quanto à fonte de selênio. As células espermáticas dos reprodutores que receberam a fonte orgânica apresentaram menor freqüência de batimentos comparada ao inorgânico $(33,16$ vs. $35,27 \mathrm{~Hz}$, respectivamente).

Em relação as velocidades de trajeto, progressiva e curvilinear, observou-se apenas uma tendência ao efeito da suplementação de selênio $(\mathrm{p}<0,10)$, sendo observado uma redução nas três velocidades nos animais suplementados (Tabela 6).

Tabela 6 - Médias e desvios-padrão das características de motilidade no sêmen in natura de cachaços durante 77 dias (Continua)

\begin{tabular}{|c|c|c|c|c|c|c|c|c|}
\hline \multirow{4}{*}{$\begin{array}{c}\text { Características } \\
\text { Espermáticas }\end{array}$} & \multicolumn{8}{|c|}{ Sêmen in natura } \\
\hline & \multicolumn{3}{|c|}{ Tratamentos (ppm) } & \multirow{3}{*}{ DP } & \multicolumn{4}{|c|}{ Probabilidade } \\
\hline & \multicolumn{2}{|c|}{$\begin{array}{c}\text { Selênio } \\
\text { Inorgânico }\end{array}$} & \multirow{2}{*}{$\begin{array}{c}\text { Selênio } \\
\text { Orgânico } \\
0,5\end{array}$} & & \multicolumn{2}{|c|}{ Tratamento } & \multirow[t]{2}{*}{$S$} & \multirow[t]{2}{*}{$\mathrm{T} * \mathrm{~S}$} \\
\hline & 0,3 & 0,5 & & & $\mathrm{C} 1$ & $\mathrm{C} 2$ & & \\
\hline $\operatorname{MT}(\%)$ & 90,54 & 89,72 & 91,06 & 5,38 & 0,9568 & 0,3326 & 0,2817 & 0,2793 \\
\hline MP (\%) & 59,42 & 56,09 & 58,74 & 14,19 & 0,6300 & 0,5177 & 0,0717 & 0,7211 \\
\hline $\operatorname{RAP}(\%)$ & 70,48 & 66,13 & 68,60 & 15,40 & 0,4821 & 0,5450 & 0,0664 & 0,6081 \\
\hline ALH $(\mu \mathrm{m})$ & 6,97 & 6,78 & 6,86 & 0,81 & 0,4672 & 0,7364 & 0,6760 & 0,5446 \\
\hline $\mathrm{BCF}(\mathrm{Hz})$ & 35,02 & 35,27 & 33,16 & 3,56 & 0,3559 & 0,0396 & 0,0588 & 0,6934 \\
\hline $\operatorname{STR}(\%)$ & 71,32 & 71,42 & 71,72 & 3,72 & 0,7696 & 0,7614 & 0,7456 & 0,6970 \\
\hline
\end{tabular}


Tabela 6 - Médias e desvios-padrão das características de motilidade no sêmen in natura de cachaços durante 77 dias

(Conclusão)

\begin{tabular}{|c|c|c|c|c|c|c|c|c|}
\hline & \multicolumn{8}{|c|}{ Sêmen in natura } \\
\hline \multirow{4}{*}{$\begin{array}{l}\text { Características } \\
\text { Espermáticas }\end{array}$} & \multicolumn{3}{|c|}{ Tratamentos (ppm) } & \multirow{4}{*}{ DP } & \multicolumn{4}{|c|}{ Probabilidade } \\
\hline & \multirow{2}{*}{\multicolumn{2}{|c|}{$\begin{array}{c}\text { Selênio } \\
\text { Inorgânico }\end{array}$}} & \multirow{3}{*}{$\begin{array}{c}\text { Selênio } \\
\text { Orgânico }\end{array}$} & & \multirow{2}{*}{\multicolumn{2}{|c|}{ Tratamento }} & \multirow{3}{*}{$S$} & \multirow{3}{*}{$\mathrm{T}^{*} \mathrm{~S}$} \\
\hline & & & & & & & & \\
\hline & 0,3 & 0,5 & & & $\mathrm{C} 1$ & $\mathrm{C} 2$ & & \\
\hline $\operatorname{LIN}(\%)$ & 42,60 & 42,19 & 42,26 & 4,59 & 0,7391 & 0,9668 & 0,6570 & 0,7341 \\
\hline $\mathrm{VAP}(\mu \mathrm{m} / \mathrm{s})$ & 76,40 & 69,90 & 69,99 & 13,57 & 0,0584 & 0,9829 & 0,1724 & 0,5448 \\
\hline $\operatorname{VSL}(\mu \mathrm{m} / \mathrm{s})$ & 55,17 & 50,48 & 50,47 & 9,57 & 0,0507 & 0,9958 & 0,1160 & 0,4098 \\
\hline $\operatorname{VCL}(\mu \mathrm{m} / \mathrm{s})$ & 134,35 & 124,3 & 124,18 & 22,25 & 0,0717 & 0,9778 & 0,4755 & 0,6532 \\
\hline
\end{tabular}

C1 (Contraste 1) = 0,3 ppm vs. 0,5 ppm Selênio; C2 (Contraste 2) = 0,5 ppm de Selênio inorgânico vs. 0,5 ppm de Selênio orgânico; $\mathrm{S}$ - semana; $\mathrm{T} * \mathrm{~S}$ - interação tratamento e semana

MT - motilidade total; MP - motilidade progressiva; RAP - células rápidas; ALH - amplitude de deslocamento lateral de cabeça; BCF - freqüência de batimento; STR - retilinearidade; LIN - linearidade; VAP - velocidade de trajeto; VSL - velocidade progressiva; VCL - velocidade curvilinear.

O efeito de semana não foi evidenciado em nenhuma das características, havendo apenas uma tendência $(\mathrm{p}<0,10)$ para a motilidade progressiva, células rápidas e freqüência de batimento. De um modo geral, as características do movimento espermático foram sutis entre os tratamentos ao longo dos 77 dias de análises (Tabela 7). 
Tabela 7 - Médias \pm desvios-padrão das características de motilidade no sêmen in natura de cachaços em intervalos de 14 dias (Continua)

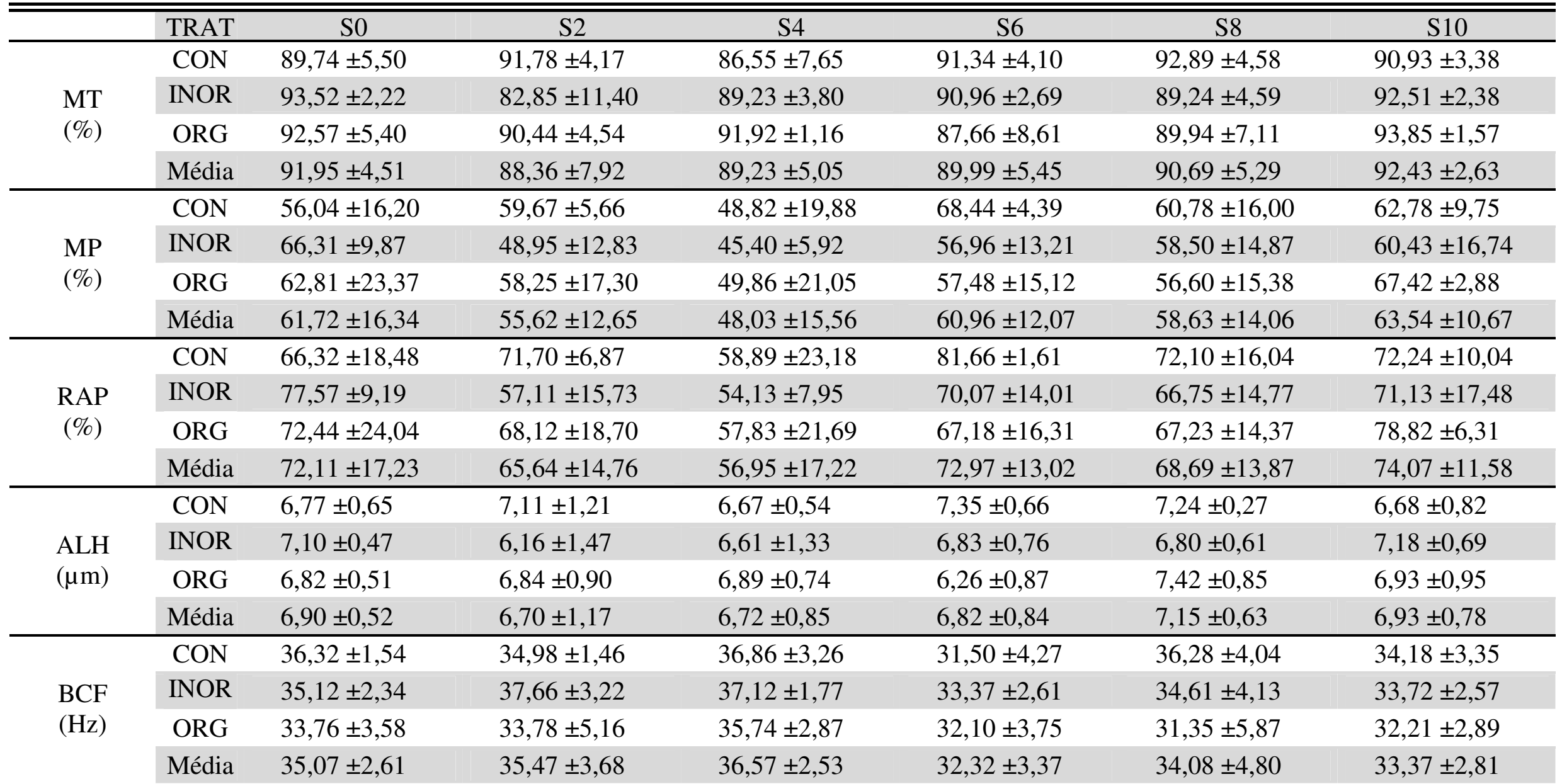

TRAT - Tratamentos; CON - Controle; INORG - Inorgânico; ORG - Orgânico; S - Semana; MT - motilidade total; MP - motilidade progressiva; RAP - células rápidas; ALH - amplitude de deslocamento lateral de cabeça; BCF - freqüência de batimento. 
Tabela 7 - Médias \pm desvios-padrão das características de motilidade no sêmen in natura de cachaços nas semanas

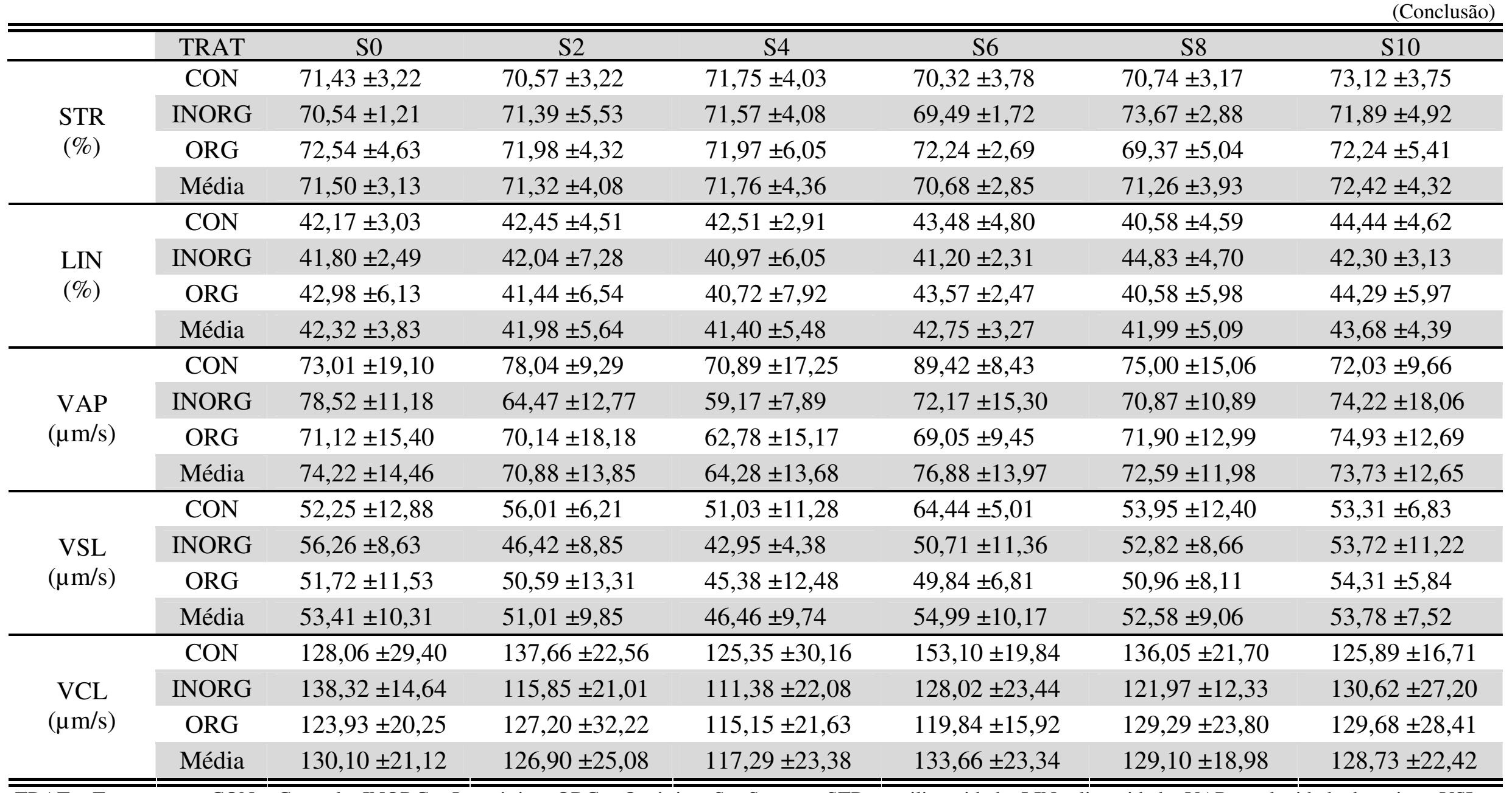

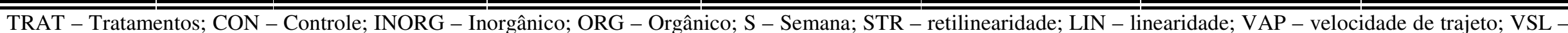
velocidade progressiva; VCL - velocidade curvilinear. 


\subsubsection{EFEITO DO SELÊNIO NAS ANORMALIDADES MORFOLÓGICAS NO SÊMEN IN NATURA}

As anormalidades morfológicas foram agrupadas em 7 categorias: normais, defeitos de acrossoma, defeitos de cabeça, defeitos de colo, defeitos de peça intermediária, defeitos de cauda e gota protoplasmática proximal. Não foram verificados efeito de interação entre tratamento e semana $(\mathrm{p}>0,05)$ e efeito de semana (Tabela 8$)$.

Observou-se em relação aos defeitos de colo que o grupo controle apresentou os menores percentuais em relação aos suplementados com selênio $(\mathrm{p}<0,05)$. Em contrapartida, os percentuais de normais, defeitos de cabeça, defeitos de peça intermediária e gota proximal foram melhores nos animais que receberam a suplementação com a fonte orgânica $(\mathrm{p}<0,05)$ (Tabela 8). Contudo, esses mesmos cachaços (tratamento orgânico) também apresentaram maiores percentuais de defeitos de cauda $(\mathrm{p}<0,05)$.

Não foram evidenciados efeito de semana em nenhuma das anormalidades morfológicas (Tabela 8).

Tabela 8 - Médias e desvios-padrão das anormalidades morfológicas no sêmen in natura de cachaços durante 77 dias

\begin{tabular}{|c|c|c|c|c|c|c|c|c|}
\hline \multirow{4}{*}{$\begin{array}{c}\text { Anormalidades } \\
\text { Morfológicas } \\
(\%)\end{array}$} & \multicolumn{8}{|c|}{ Sêmen in natura } \\
\hline & \multicolumn{3}{|c|}{ Tratamentos (ppm) } & \multirow{3}{*}{ DP } & \multicolumn{4}{|c|}{ Probabilidade } \\
\hline & \multicolumn{2}{|c|}{$\begin{array}{c}\text { Selênio } \\
\text { Inorgânico }\end{array}$} & \multirow{2}{*}{$\begin{array}{c}\begin{array}{c}\text { Selênio } \\
\text { Orgânico }\end{array} \\
0,5\end{array}$} & & \multicolumn{2}{|c|}{ Tratamento } & \multirow[t]{2}{*}{$\mathrm{S}$} & \multirow[t]{2}{*}{$\mathrm{T}^{*} \mathrm{~S}$} \\
\hline & 0,3 & 0,5 & & & $\mathrm{C} 1$ & $\mathrm{C} 2$ & & \\
\hline Normal & 85,29 & 82,71 & 92,08 & 14,40 & 0,1983 & $\mathbf{0 , 0 2 7 1}$ & 0,3260 & 0,2570 \\
\hline Acrossoma & 0,42 & 0,73 & 0,42 & 1,01 & 0,7460 & 0,4721 & 0,2177 & 0,2730 \\
\hline Cabeça & 3,69 & 5,27 & 0,92 & 5,41 & 0,1475 & 0,0060 & 0,2851 & 0,4317 \\
\hline Colo & 0,19 & 0,81 & 0,50 & 1,00 & $\mathbf{0 , 0 3 3 9}$ & 0,5365 & 0,1184 & 0,4131 \\
\hline Peça & 0,25 & 0,23 & 0,02 & 0,22 & 0,3119 & $\mathbf{0 , 0 4 2 3}$ & 0,4375 & 0,1550 \\
\hline Cauda & 3,02 & 1,23 & 3,60 & 3,02 & 0,0814 & 0,0016 & 0,6543 & 0,7658 \\
\hline Gota proximal & 7,14 & 9,02 & 2,46 & 8,89 & 0,1186 & 0,0161 & 0,5561 & 0,3036 \\
\hline
\end{tabular}

C1 (Contraste 1) =0,3 ppm vs. 0,5 ppm Selênio; C2 (Contraste 2) = 0,5 ppm de Selênio inorgânico vs. 0,5 ppm de Selênio orgânico; $\mathrm{S}$ - semana; $\mathrm{T} * \mathrm{~S}$ - interação tratamento e semana, DP - desvio-padrão. 
Nas semanas analisadas o percentual de espermatozóides normais foi elevado em todos os tratamentos, sendo o tratamento orgânico àquele que manteve as maiores porcentagens na maioria das semanas. Já os defeitos de cabeça, peça intermediária e gota proximal foram baixos em todos os tratamentos, mas o orgânico apresentou os menores percentuais comparativamente aos demais tratamentos (Tabela 9).

Em contrapartida, foram evidenciados maiores percentuais de defeitos de colo nos tratamentos suplementados, concentrando os maiores valores na quarta e na sexta semana em comparação ao controle (Tabela 9). E na maioria das semanas, o tratamento orgânico também apresentou maiores percentuais de alterações na cauda do espermatozóide 
Tabela 9- Médias \pm desvios-padrão de anormalidades morfológicas no sêmen in natura de cachaços em intervalos de 14 dias (Continua)

\begin{tabular}{|c|c|c|c|c|c|c|c|}
\hline & TRAT & S0 & $\mathrm{S} 2$ & $\mathrm{~S} 4$ & S6 & S8 & S10 \\
\hline \multirow{4}{*}{$\underset{(\%)}{\text { Normal }}$} & $\mathrm{CON}$ & $84,75 \pm 8,47$ & $81,25 \pm 11,81$ & $85,37 \pm 5,51$ & $88,25 \pm 4,05$ & $87,87 \pm 4,19$ & $84,25 \pm 5,98$ \\
\hline & INORG & $89,37 \pm 12,66$ & $70,25 \pm 41,36$ & $76,87 \pm 29,15$ & $84,37 \pm 15,48$ & $89,00 \pm 14,16$ & $86,37 \pm 14,55$ \\
\hline & ORG & $94,25 \pm 4,35$ & $95,00 \pm 3,03$ & $91,50 \pm 4,02$ & $91,62 \pm 9,28$ & $87,00 \pm 14,23$ & $93,12 \pm 5,59$ \\
\hline & Média & $89,46 \pm 9,21$ & $82,17 \pm 24,88$ & $84,58 \pm 16,84$ & $88,08 \pm 10,14$ & $87,96 \pm 10,74$ & $87,92 \pm 9,57$ \\
\hline \multirow{4}{*}{$\begin{array}{l}\text { Acrossoma } \\
(\%)\end{array}$} & $\mathrm{CON}$ & 0 & $0,37 \pm 0,75$ & $0,50 \pm 0,71$ & $0,37 \pm 0,25$ & $0,87 \pm 1,11$ & $0,37 \pm 0,48$ \\
\hline & INORG & $0,25 \pm 0,29$ & $1,62 \pm 3,25$ & $1,12 \pm 0,75$ & $0,62 \pm 1,25$ & $0,37 \pm 0,48$ & $0,37 \pm 0,75$ \\
\hline & $\mathrm{ORG}$ & $0,25 \pm 0,50$ & $0,25 \pm 0,29$ & $0,12 \pm 0,25$ & 0 & $1,37 \pm 1,80$ & $0,50 \pm 0$ \\
\hline & Média & $0,17 \pm 0,32$ & $0,75 \pm 1,86$ & $0,58 \pm 0,70$ & $0,33 \pm 0,72$ & $0,87 \pm 1,21$ & $0,42 \pm 0,47$ \\
\hline \multirow{4}{*}{$\begin{array}{c}\text { Cabeça } \\
(\%)\end{array}$} & $\mathrm{CON}$ & $3,37 \pm 2,87$ & $5,75 \pm 6,07$ & $3,50 \pm 2,27$ & $2,25 \pm 2,02$ & $3,62 \pm 5,26$ & $3,62 \pm 2,87$ \\
\hline & INORG & $2,87 \pm 3,09$ & $12,50 \pm 16,77$ & $6,00 \pm 7,79$ & $4,00 \pm 2,91$ & $4,12 \pm 6,41$ & $2,12 \pm 3,92$ \\
\hline & ORG & $0,75 \pm 0,29$ & $0,62 \pm 0,63$ & $1,25 \pm 1,26$ & $1,50 \pm 1,22$ & $0,87 \pm 0,63$ & $0,50 \pm 0,41$ \\
\hline & Média & $2,33 \pm 2,51$ & $6,29 \pm 10,61$ & $3,58 \pm 4,74$ & $2,58 \pm 2,24$ & $2,87 \pm 4,59$ & $2,08 \pm 2,87$ \\
\hline \multirow{4}{*}{$\begin{array}{c}\text { Colo } \\
(\%)\end{array}$} & $\mathrm{CON}$ & 0 & $0,87 \pm 1,03$ & $0,25 \pm 0,50$ & 0 & 0 & 0 \\
\hline & INORG & $0,12 \pm 0,25$ & $0,75 \pm 0,87$ & $1,75 \pm 1,44$ & $2,00 \pm 2,34$ & 0 & $0,25 \pm 0,50$ \\
\hline & $\mathrm{ORG}$ & $0,25 \pm 0,29$ & $0,12 \pm 0,25$ & $1,12 \pm 1,31$ & $0,50 \pm 0,41$ & $0,87 \pm 1,75$ & $0,12 \pm 0,25$ \\
\hline & Média & $0,12 \pm 0,23$ & $0,58 \pm 0,79$ & $1,04 \pm 1,23$ & $0,83 \pm 1,53$ & $0,29 \pm 1,01$ & $0,12 \pm 0,31$ \\
\hline \multirow{4}{*}{$\begin{array}{c}\text { Peça } \\
\text { intermédiária } \\
(\%)\end{array}$} & $\mathrm{CON}$ & 0 & $0,75 \pm 1,50$ & $0,37 \pm 0,25$ & 0 & $0,12 \pm 0,25$ & $0,25 \pm 0,50$ \\
\hline & INORG & $0,25 \pm 0,50$ & $0,12 \pm 0,25$ & $0,25 \pm 0,29$ & $0,75 \pm 0,87$ & 0 & 0 \\
\hline & $\mathrm{ORG}$ & $0,12 \pm 0,25$ & 0 & 0 & 0 & 0 & 0 \\
\hline & Média & $0,12 \pm 0,31$ & $0,29 \pm 0,86$ & $0,21 \pm 0,26$ & $0,25 \pm 0,58$ & $0,04 \pm 0,14$ & $0,08 \pm 0,29$ \\
\hline
\end{tabular}

TRAT - Tratamentos; CON - Controle; INORG - Inorgânico; ORG - Orgânico; S - Semana. 


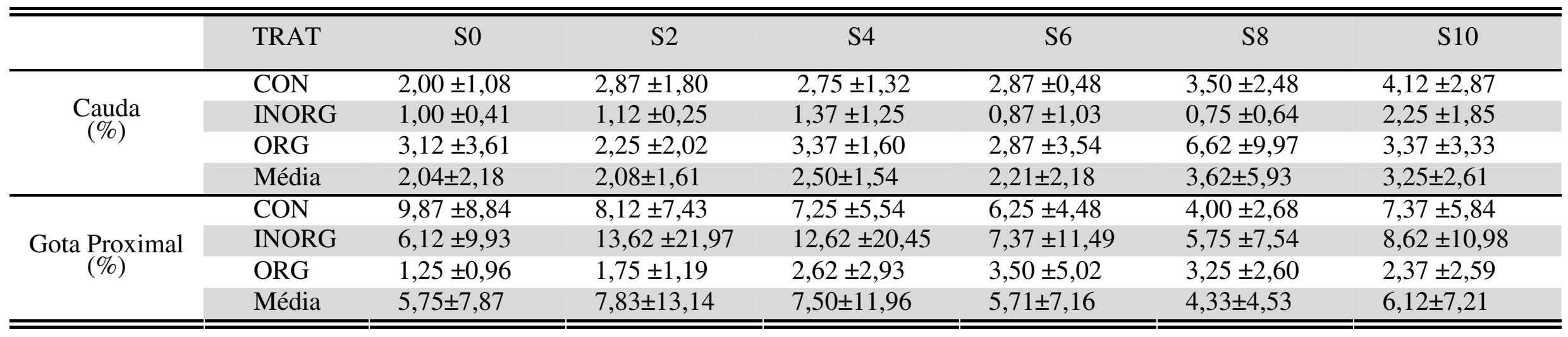

Tabela 9 - Médias \pm desvios-padrão de anormalidades morfológicas no sêmen in natura de cachaços em intervalos de 14 dias

TRAT - Tratamentos; CON - Controle; INORG - Inorgânico; ORG - Orgânico; S - Semana. 


\subsubsection{EFEITO DO SELÊNIO NA ATIVIDADE DA ENZIMA FOSFOLIPÍDIO HIDROPERÓXIDO GLUTATIONA PEROXIDASE (PHGPX) NO SÊMEN IN NATURA}

A atividade da enzima PHGPx mensurada nos espermatozóides foi influenciada pela suplementação de selênio apresentando uma diferença favorável ao $0,5 \mathrm{ppm}$ de selênio equivalente a 43,68 mU/mg de proteína (131,44 vs. 175,12 mU/mg de proteína , 0,3 vs. 0,5 ppm de selênio, respectivamente). Em relação à fonte, também foi verificado efeito $(p<0,05)$, tendo a fonte orgânica apresentado maior atividade (145,30 vs 204,95 mU/mg de proteína, selenito de sódio vs. selênio orgânico, respectivamente), equivalendo a 59,65 mU/mg de proteína (Tabela 10). Detectou-se efeito uma tendência ao efeito de interação $(p<0,10)$ e não houve efeito para semana $(\mathrm{p}>0,05)$.

Tabela 10 - Médias e desvios-padrão da atividade da enzima PHGPx no sêmen in natura de cachaços durante 77 dias

\begin{tabular}{|c|c|c|c|c|c|c|c|c|}
\hline & \multicolumn{8}{|c|}{ Sêmen in natura } \\
\hline & \multicolumn{3}{|c|}{ Tratamentos (ppm) } & & \multicolumn{4}{|c|}{ Probabilidade } \\
\hline & \multicolumn{2}{|c|}{$\begin{array}{c}\text { Selênio } \\
\text { Inorgânico }\end{array}$} & \multirow{2}{*}{$\begin{array}{c}\text { Selênio } \\
\text { Orgânico }\end{array}$} & \multirow[t]{2}{*}{ DP } & \multicolumn{2}{|c|}{ Tratamento } & \multirow[t]{2}{*}{$\mathrm{S}$} & \multirow[t]{2}{*}{$\mathrm{T} * \mathrm{~S}$} \\
\hline & 0,3 & 0,5 & & & $\mathrm{C} 1$ & $\mathrm{C} 2$ & & \\
\hline PHGPx & 131,44 & 145,30 & 204,95 & 50,65 & $<, 0001$ & $<, 0001$ & 0,1749 & 0,0914 \\
\hline
\end{tabular}

C1 (Contraste 1) =0,3 ppm vs. 0,5 ppm Selênio; C2 (Contraste 2) = 0,5 ppm de Selênio inorgânico vs. 0,5 ppm de Selênio orgânico; $\mathrm{S}$ - semana; $\mathrm{T} * \mathrm{~S}$ - interação tratamento e semana

DP - desvio-padrão; atividade de PHGPx - mU/mg de proteína.

Observou-se em todas as semanas que o tratamento orgânico apresentou os maiores valores de atividade comparado aos demais tratamentos (Tabela 11). E ao longo das semanas essa atividade foi aumentando gradativamente no tratamento orgânico, mas o mesmo não aconteceu nos demais tratamentos. 
Tabela 11- Médias \pm desvios-padrão da atividade da enzima PHGPx (mU/mg de proteína) no sêmen in natura de cachaços em intervalos de 14 dias

\begin{tabular}{ccccc}
\hline \hline SEMANAS & CONTROLE & INORGÂNICO & ORGÂNICO & MÉDIAS \\
\hline S0 & $148,53 \pm 29,78$ & $143,36 \pm 42,05$ & $166,93 \pm 16,70$ & $152,94 \pm 30,20$ \\
S2 & $126,28 \pm 34,44$ & $121,80 \pm 25,27$ & $168,73 \pm 23,61$ & $138,94 \pm 33,73$ \\
S4 & $133,28 \pm 36,84$ & $151,57 \pm 10,90$ & $188,12 \pm 46,54$ & $157,66 \pm 39,50$ \\
S6 & $111,27 \pm 24,88$ & $171,45 \pm 39,54$ & $219,65 \pm 50,42$ & $167,46 \pm 58,60$ \\
S8 & $139,83 \pm 45,95$ & $145,84 \pm 26,65$ & $222,85 \pm 53,72$ & $169,51 \pm 55,82$ \\
S10 & $129,47 \pm 51,50$ & $137,75 \pm 23,00$ & $263,40 \pm 39,55$ & $176,87 \pm 73,42$ \\
\hline \hline
\end{tabular}

Controle (0,3 ppm selênio inorgânico); Inorgânico (0,5 ppm selênio inorgânico); Orgânico (0,5 ppm de Selênio orgânico); S - semana.

\subsubsection{CONCENTRAÇÃO DE SELÊNIO NO PLASMA SANGUÍNEO E SEMINAL NAS SEMANAS}

Foi observado maior $(\mathrm{p}<0,05)$ concentração de selênio no plasma sanguíneo e seminal, nos animais do tratamento orgânico. A suplementação de selênio, independente da fonte também aumentou a concentração de selênio no plasma sanguíneo e seminal (Tabela 12).

As amostras de ração foram coletadas, a fim de se determinar a concentração de selênio nas três diferentes dietas após a fabricação das mesmas. O resultado foi condizente com o esperado, confirmando as quantidades de selênio pré-estabelecidas nos tratamentos.

Tabela 12 - Médias e desvios-padrão da concentração de selênio durante 77 dias

\begin{tabular}{|c|c|c|c|c|c|c|c|c|}
\hline & \multicolumn{8}{|c|}{ Sêmen in natura } \\
\hline \multirow{3}{*}{$\begin{array}{c}\text { Concentração } \\
\text { de Selênio } \\
(\mathrm{ng} / \mathrm{mL})\end{array}$} & \multicolumn{3}{|c|}{ Tratamentos (ppm) } & \multirow{3}{*}{ DP } & \multicolumn{4}{|c|}{ Probabilidade } \\
\hline & \multicolumn{2}{|c|}{$\begin{array}{c}\text { Selênio } \\
\text { Inorgânico }\end{array}$} & \multirow{2}{*}{$\begin{array}{c}\text { Selênio } \\
\text { Orgânico }\end{array}$} & & \multicolumn{2}{|c|}{ Tratamento } & \multirow[t]{2}{*}{ S } & \multirow[t]{2}{*}{$\mathrm{T}^{*} \mathrm{~S}$} \\
\hline & 0.3 & 0.5 & & & $\mathrm{C} 1$ & $\mathrm{C} 2$ & & \\
\hline Plasma sangue & 131 & 135 & 164 & 0,03 & 0,0008 & $<, 0001$ & 0,0263 & 0,1447 \\
\hline Plasma seminal & 18 & 19 & 24 & 0,007 & 0,1654 & 0,0023 & $\mathbf{0 , 0 0 3 7}$ & 0,7036 \\
\hline
\end{tabular}

C1 (Contraste 1) $=0.3$ ppm vs 0.5 ppm Selênio; C2 (Contraste 2) $=0.5$ ppm de Selênio inorgânico vs 0.5 ppm de Selênio orgânico; $\mathrm{S}$ - semana; $\mathrm{T} * \mathrm{~S}$ - interação tratamento e semana

$\mathrm{DP}$ - desvio-padrão; P - plasma 
Previamente ao início do experimento realizou-se duas coletas de plasma sangüíneo e seminal com intervalos de 14 dias (semana -21 e semana -7) e constatou-se que os grupos apresentavam-se com concentrações de selênio muito próximas antes de receberem as dietas experimentais (Tabela 13). O grupo controle iniciou com $132 \mathrm{ng} / \mathrm{mL}$ de selênio no plasma sangüíneo, o inorgânico com 134,5 ng/mL e o orgânico com 136,5 ng/mL. Já no plasma seminal os valores foram 18,85 ng/mL, 16,35 ng/mL e 21,25 ng/mL, controle, inorgânico e orgânico, respectivamente. No decorrer das semanas de análise foram observadas variações em todos os tratamentos, sendo averiguado que o orgânico apresentou os maiores valores e as maiores variações. 
Tabela 13- Médias \pm desvios-padrão da concentração de selênio em ng/mL em intervalos de 14 dias

\begin{tabular}{ccccccccc}
\hline \hline SELENNIO & TRAT & S-21 & S-7 & S1 & S3 & S5 & S7 \\
\hline & CON & $125 \pm 0,01$ & $139 \pm 0,03$ & $143 \pm 0,02$ & $115 \pm 0,01$ & $138 \pm 0,02$ & $128 \pm 0,02$ & $125 \pm 0,01$ \\
PLASMA & INORG & $126 \pm 0,01$ & $143 \pm 0,04$ & $130 \pm 0,01$ & $131 \pm 0,02$ & $146 \pm 0,03$ & $141 \pm 0,01$ & $128 \pm 0,01$ \\
SANGUE & ORG & $119 \pm 0,003$ & $154 \pm 0,04$ & $170 \pm 0,03$ & $167 \pm 0,01$ & $180 \pm 0,01$ & $178 \pm 0,01$ & $181 \pm 0,01$ \\
& Média & $123 \pm 0,01^{\mathrm{b}}$ & $146 \pm 0,03^{\mathrm{a}}$ & $148 \pm 0,03^{\mathrm{a}}$ & $137 \pm 0,02^{\mathrm{a}, \mathrm{b}}$ & $154 \pm 0,03^{\mathrm{a}}$ & $149 \pm 0,03^{\mathrm{a}}$ & $145 \pm 0,03^{\mathrm{a}} \mathrm{b}$ \\
\hline \multirow{3}{*}{ PLASMA } & CON & $19 \pm 0,01$ & $13,7 \pm 0,003$ & $16,5 \pm 0,003$ & $18,0 \pm 0,01$ & $17,7 \pm 0,01$ & $21,5 \pm 0,01$ & $21,2 \pm 0,01$ \\
SEMINAL & ONORG & $20 \pm 0,01$ & $17,7 \pm 0,01$ & $19 \pm 0,01$ & $15,7 \pm 0,003$ & $14,2 \pm 0,003$ & $22,0 \pm 0,01$ & $23 \pm 0,005$ \\
& ORG & $20 \pm 0,005$ & $22,5 \pm 0,01$ & $22,2 \pm 0,01$ & $17,2 \pm 0,004$ & $23,2 \pm 0,004$ & $31,2 \pm 0,01$ & $30,0 \pm 0,01$ \\
& Média & $19,8 \pm 0,01^{\mathrm{a}, \mathrm{b}}$ & $18,0 \pm 0,01^{\mathrm{b}}$ & $19,2 \pm 0,01^{\mathrm{b}}$ & $17,0 \pm 0,005^{\mathrm{b}}$ & $18,4 \pm 0,005^{\mathrm{b}}$ & $24,9 \pm 0,01^{\mathrm{a}}$ & $24,9 \pm 0,01^{\mathrm{a}}$ \\
\hline \hline
\end{tabular}

$\overline{\text { TRAT - Tratamentos; CON - Controle; INORG - Inorgânico; ORG - Orgânico; S - Semana. }}$

${ }_{\mathrm{a}, \mathrm{b}, \mathrm{c}}$ Letras minúsculas diferentes na mesma linha, diferem estatisticamente $\mathrm{p}<0,05$ (teste LSD). 


\subsubsection{CORRELAÇÃO ENTRE AS CARACTERÍSTICAS ESPERMÁTICAS E A ENZIMA FOSFOLIPÍDIO HIDROPERÓXIDO GLUTATIONA PEROXIDASE}

Por meio da análise de correlação verificou-se que o aumento na concentração de selênio no plasma sangüíneo não foi correlacionado com a concentração de selênio no plasma seminal $(r=0,14, p=0,2542)$. No entanto, o aumento de selênio no plasma seminal foi diretamente correlacionado com a maior atividade da PHGPx no espermatozóide ( $\mathrm{r}=0,27$, $\mathrm{p}=0,0209)$, bem como com o percentual de células normais $(\mathrm{r}=0,26, \mathrm{p}=0,0297)$. Este aumento do selênio ainda foi inversamente correlacionado com os defeitos de cabeça da célula espermática $(r=0,25, \mathrm{p}=0,0305)$, defeito de acrossoma $(\mathrm{r}=0,23, \mathrm{p}=0,0493)$ defeito de peça intermediária $(\mathrm{r}=0,26, \mathrm{p}=0,0242)$ e defeitos de gota proximal $(\mathrm{r}=0,24, \mathrm{p}=0,0373)$.

\subsection{PARTE 2: EFEITO DA SUPLEMENTAÇÃO ORAL DE SELÊNIO SOBRE AS CARACTERÍSTICAS DO SÊMEN REFRIGERADO DE CACHAÇOS}

Neste tópico foram apresentados os resultados do efeito do selênio nas características do sêmen refrigerado de cachaços em diferentes tempos: 0, 24, 48 e 72 horas após a diluição.

\subsubsection{EFEITO DO SELÊNIO NA INTEGRIDADE DA MEMBRANA PLASMÁtiCA E ACROSSOMAL, POTENCIAL DE MEMBRANA MITOCONDRIAL E PEROXIDAÇÃO DAS MEMBRANAS NO SÊMEN REFRIGERADO}

Na avaliação do sêmen refrigerado não foi detectada interação entre tratamento e períodos $(\mathrm{p}>0,05)$ para as integridades de membranas, potencial de membrana mitocondrial e peroxidação das membranas. A suplementação com selênio orgânico não exerceu influência sobre as características analisadas, apresentando valores intermediários logo após o controle. Efeito de período $(\mathrm{p}<0,05)$ foi observado para todas as características. 
O percentual de células com membrana plasmática íntegra foi maior $(\mathrm{p}<0,05)$ no tratamento controle em comparação aos demais. Essas células mantiveram a mesma característica apresentada no sêmen in natura (Tabela 14). Em relação às células com potencial mitocondrial, apenas uma tendência a significância foi verificada para o efeito de suplementação de selênio ( $\mathrm{p}=0,0685)$ (Tabela 14).

Tabela 14 - Médias e desvios-padrão de integridade da membrana plasmática e acrossomal, potencial mitocondrial e peroxidação de membrana no sêmen refrigerado de cachaços durante 72 horas

\begin{tabular}{|c|c|c|c|c|c|c|c|c|}
\hline \multirow{4}{*}{$\begin{array}{c}\text { Características } \\
\text { Espermáticas }\end{array}$} & \multicolumn{8}{|c|}{ Sêmen refrigerado } \\
\hline & \multicolumn{3}{|c|}{ Tratamentos (ppm) } & & \multicolumn{4}{|c|}{ Probabilidade } \\
\hline & \multicolumn{2}{|c|}{$\begin{array}{c}\text { Selênio } \\
\text { Inorgânico }\end{array}$} & \multirow{2}{*}{$\begin{array}{c}\text { Selênio } \\
\text { Orgânico } \\
0,5\end{array}$} & \multirow[t]{2}{*}{ DP } & \multicolumn{2}{|c|}{ Tratamento } & \multirow[t]{2}{*}{$\mathrm{P}$} & \multirow[t]{2}{*}{$\mathrm{T}^{*} \mathrm{P}$} \\
\hline & 0,3 & 0,5 & & & $\mathrm{C} 1$ & $\mathrm{C} 2$ & & \\
\hline $\operatorname{AIMI}(\%)$ & 72,80 & 70,76 & 71,45 & 11,62 & 0,1685 & 0,3884 & $<, 0001$ & 0,4925 \\
\hline $\operatorname{MAI}(\%)$ & 76,02 & 75,61 & 75,76 & 10,44 & 0,9332 & 0,9720 & $<, 0001$ & 0,7416 \\
\hline MI (\%) & 86,23 & 83,48 & 81,45 & 9,67 & 0,0006 & 0,1306 & $<, 0001$ & 0,5062 \\
\hline $\mathrm{CP}(\%)$ & 72,04 & 70,32 & 67,55 & 13,63 & 0,0685 & 0,1505 & $<, 0001$ & 0,2516 \\
\hline IFMI (u.a.) & 126,52 & 124,71 & 126,01 & 249,30 & 0,9038 & 0,9072 & $<, 0001$ & 0,5124 \\
\hline
\end{tabular}

C1 (Contraste 1) = 0,3 ppm vs. 0,5 ppm Selênio; C2 (Contraste 2) =0,5 ppm de Selênio inorgânico vs. 0,5 ppm de Selênio orgânico; $\mathrm{P}$ - período; $\mathrm{T} * \mathrm{P}$ - interação tratamento e período

AIMI - membrana plasmática e acrossomal íntegra; MAI - membrana acrossomal íntegra; MI - membrana plasmática íntegra; $\mathrm{CP}$ - potencial de membrana mitocondrial; IFMI - intensidade da fluorescência da população espermática com membrana plasmática íntegra.

Para a característica células com acrossoma e membrana plasmática íntegra (AIMI) foi verificado no primeiro período um percentual elevado de $75,17 \%$ que no decorrer das horas foram diminuindo não passando de $71,4 \%$ no último período. Somente o período 0 hora diferiu dos demais (Tabela 15).

Já para as células com acrossoma íntegro também notou-se que no primeiro período havia um maior percentual dessas células $(79,26 \%)$, mas que reduziu-se ao longo dos períodos, principalmente, 48 horas. De maneira semelhante à característica anterior o período 0 horas diferiu dos demais períodos.

Em praticamente todos os períodos analisados, os percentuais de células com membrana plasmática íntegra se mantiveram altos, acima de 81,0\%. Somente foram detectadas diferenças entre os períodos de 24 e 72 horas. Além disso, houve efeito de suplementação de selênio empregada, independente da fonte, sendo que os animais que 
receberam a dieta com 0,3 ppm apresentaram maior percentual de células com membrana plasmática íntegra. 
Tabela 15 - Médias \pm desvios-padrão das características de integridade da membrana plasmática e acrossomal, potencial mitocondrial e peroxidação de membrana no sêmen refrigerado de cachaços em intervalos de 24 horas

\begin{tabular}{|c|c|c|c|c|c|}
\hline & TRAT & $0 \mathrm{~h}$ & $24 \mathrm{~h}$ & $48 \mathrm{~h}$ & $72 \mathrm{~h}$ \\
\hline \multirow{4}{*}{$\begin{array}{c}\text { AIMI } \\
(\%)\end{array}$} & $\mathrm{CON}$ & $75,70 \pm 5,90$ & $71,65 \pm 8,29$ & $70,87 \pm 10,84$ & $72,99 \pm 7,56$ \\
\hline & INORG & $72,54 \pm 18,81$ & $67,54 \pm 12,81$ & $69,32 \pm 14,14$ & $70,02 \pm 13,83$ \\
\hline & ORG & $74,07 \pm 9,31$ & $70,37 \pm 10,62$ & $70,15 \pm 12,55$ & $71,20 \pm 9,26$ \\
\hline & Média & $74,10 \pm 12,48^{a}$ & $69,89 \pm 10,69^{b}$ & $70,12 \pm 12,42^{a b}$ & $71,40 \pm 10,48^{a}$ \\
\hline \multirow{4}{*}{$\begin{array}{c}\text { MAI } \\
(\%)\end{array}$} & $\mathrm{CON}$ & $79,42 \pm 5,18$ & $75,64 \pm 6,73$ & $73,41 \pm 9,65$ & $75,63 \pm 6,29$ \\
\hline & INORG & $76,92 \pm 17,61$ & $74,58 \pm 9,08$ & $73,16 \pm 11,90$ & $74,47 \pm 13,46$ \\
\hline & ORG & $78,42 \pm 9,55$ & $75,38 \pm 9,26$ & $73,84 \pm 11,60$ & $75,38 \pm 9,20$ \\
\hline & Média & $78,25 \pm 11,82^{a}$ & $75,21 \pm 8,32^{b}$ & $73,47 \pm 10,94^{b}$ & $75,16 \pm 9,96^{b}$ \\
\hline \multirow{4}{*}{$\begin{array}{l}\text { MI } \\
(\%)\end{array}$} & $\mathrm{CON}$ & $87,49 \pm 3,56$ & $84,04 \pm 8,28$ & $85,57 \pm 9,96$ & $87,80 \pm 5,42$ \\
\hline & INORG & $88,47 \pm 10,49$ & $79,81 \pm 9,23$ & $83,45 \pm 11,26$ & $83,50 \pm 8,34$ \\
\hline & $\mathrm{ORG}$ & $84,17 \pm 8,51$ & $79,59 \pm 11,18$ & $80,58 \pm 12,58$ & $81,46 \pm 10,11$ \\
\hline & Média & $86,71 \pm 8,16^{\mathrm{a}}$ & $81,17 \pm 9,73^{b}$ & $83,20 \pm 11,35^{a b}$ & $84,37 \pm 8,49^{a}$ \\
\hline \multirow{4}{*}{$\begin{array}{l}\mathrm{CP} \\
(\%)\end{array}$} & $\mathrm{CON}$ & $76,65 \pm 14,61$ & $71,00 \pm 13,01$ & $68,21 \pm 10,70$ & $72,29 \pm 14,54$ \\
\hline & INORG & $76,59 \pm 11,13$ & $66,19 \pm 12,30$ & $65,91 \pm 9,82$ & $72,84 \pm 17,18$ \\
\hline & ORG & $76,90 \pm 11,37$ & $66,16 \pm 11,79$ & $62,69 \pm 12,20$ & $64,47 \pm 15,12$ \\
\hline & Média & $76,71 \pm 12,29^{a}$ & $67,81 \pm 12,42^{b}$ & $65,60 \pm 11,03^{b}$ & $69,86 \pm 15,90^{b}$ \\
\hline \multirow{4}{*}{$\begin{array}{l}\text { IFMI } \\
\text { (u.a.) }\end{array}$} & $\mathrm{CON}$ & $126,58 \pm 46,13$ & $145,33 \pm 71,59$ & $125,67 \pm 75,62$ & $108,50 \pm 67,54$ \\
\hline & INORG & $120,48 \pm 45,19$ & $149,83 \pm 88,48$ & $121,42 \pm 72,95$ & $108,00 \pm 64,61$ \\
\hline & ORG & $116.30 \pm 80,17$ & $158.96 \pm 112.51$ & $132.00 \pm 90.54$ & $96.37 \pm 65.67$ \\
\hline & Média & $121,20 \pm 58,53^{b}$ & $151.39 \pm 91,31^{\mathrm{a}}$ & $126.36 \pm 79.06^{\mathrm{b}}$ & $104.29 \pm 65.26^{\mathrm{b}}$ \\
\hline
\end{tabular}

TRAT - Tratamentos; CON - Controle; INORG - Inorgânico; ORG - Orgânico; AIMI - membrana plasmática e acrossomal íntegra; MAI - membrana acrossomal íntegra; MI - membrana plasmática íntegra; CP - potencial de membrana mitocondrial; IFMI - intensidade da fluorescência da população espermática com membrana plasmática íntegra

${ }^{a, b, c}$ Letras minúsculas diferentes na mesma linha, diferem estatisticamente $\mathrm{p}<0,05$ (teste LSD). 
A média dos tratamentos que receberam suplementação de $0,5 \mathrm{ppm}$ de selênio, independente da fonte, foi menor em comparação ao 0,3 ppm $(68,93 \%$ e 72,04\%, respectivamente), demonstrando que o potencial mitocondrial foi influenciado pela maior suplementação de selênio.

Houve um aumento na peroxidação das membranas espermáticas ao longo dos períodos, verificando-se um aumento de 1,24 vezes do período 0 para 24 horas, após o mesmo foram verificadas reduções de 1,19 vezes de 24 para 48 horas e de 1,21 vezes. de 48 para 72 horas.

\subsubsection{EFEITO DO SELÊNIO NAS CARACTERÍSTICAS DO MOVIMENTO ESPERMÁTICO NO SÊMEN REFRIGERADO}

Em relação à motilidade total, progressiva, células rápidas, amplitude de deslocamento lateral de cabeça, retilinearidade, linearidade e as velocidades progressiva, de trajeto e curvilinear não houve interação significativa entre tratamento e período (Tabela 16).

Ao analisarmos o efeito da fonte, verificou-se que o tratamento orgânico melhorou $(\mathrm{p}<0,05)$ as motilidades total e progressiva e células rápidas em comparação tanto ao inorgânico. Os percentuais mais baixos foram observados nos animais que receberam o tratamento inorgânico e os intermediários no tratamento controle. Embora a porcentagem de células com potencial mitocondrial tenha sido inferior no tratamento orgânico em relação aos demais, a determinação na concentração de ATP na peça intermediária é de fundamental importância para associarmos a esta melhora encontrada na motilidade espermática.

Ao considerarmos o tratamento foi observado efeito da fonte para as velocidades VAP e VSL $(\mathrm{P}<0,05)$ (Tabela 16).

Ao verificarmos o contraste 2 para as velocidades de trajeto e progressiva observamos que ambas apresentaram maior velocidade no tratamento orgânico em relação ao inorgânico.

Já para efeito de tratamento notou-se efeito da fonte para frequiência de batimentos (Contraste 2 - orgânico x inorgânico) (Tabela 16) e tendência para linearidade. Efeito de suplementação de selênio também foi constatada para a retilinearidade e a linearidade (Tabela 16).

As células espermáticas dos reprodutores que receberam a suplementação inorgânica apresentaram maior frequiência de batimentos quando comparado ao orgânico. 
Já para retilinearidade e linearidade o tratamento controle $(0,3 \mathrm{ppm})$ apresentou os maiores percentuais comparado aos tratamentos orgânico e inorgânico (ambos com 0,5 ppm).

Tabela 16 - Médias e desvios-padrão das características da motilidade no sêmen refrigerado de cachaços durante 72 horas

\begin{tabular}{|c|c|c|c|c|c|c|c|c|}
\hline \multirow{4}{*}{$\begin{array}{c}\text { Características } \\
\text { Espermáticas }\end{array}$} & \multicolumn{8}{|c|}{ Sêmen refrigerado } \\
\hline & \multicolumn{3}{|c|}{ Tratamentos (ppm) } & & \multicolumn{4}{|c|}{ Probabilidade } \\
\hline & \multicolumn{2}{|c|}{$\begin{array}{c}\text { Selênio } \\
\text { Inorgânico }\end{array}$} & \multirow{2}{*}{$\begin{array}{c}\text { Selênio } \\
\text { Orgânico } \\
0,5\end{array}$} & \multirow[t]{2}{*}{ DP } & \multicolumn{2}{|c|}{ Tratamento } & \multirow[t]{2}{*}{$\mathrm{P}$} & \multirow[t]{2}{*}{$\mathrm{T} * \mathrm{P}$} \\
\hline & 0,3 & 0,5 & & & $\mathrm{C} 1$ & $\mathrm{C} 2$ & & \\
\hline $\mathrm{MT}(\%)$ & 81,95 & 79,88 & 84,41 & 12,77 & 0,6836 & 0,0044 & $<, 0001$ & 0,8680 \\
\hline $\mathrm{MP}(\%)$ & 40,96 & 35,73 & 44,27 & 19,40 & 0,5963 & 0,0014 & 0,0174 & 0,4183 \\
\hline RAP (\%) & 48,25 & 43,79 & 53,07 & 21,84 & 0,9698 & 0,0025 & $<, 0001$ & 0,8458 \\
\hline $\mathrm{ALH}(\mu \mathrm{m})$ & 5,83 & 5,98 & 6,08 & 1,20 & 0,1990 & 0,5161 & 0,0516 & 0,4239 \\
\hline $\mathrm{BCF}(\mathrm{Hz})$ & 38,95 & 39,59 & 37,61 & 4,98 & 0,5209 & 0,0093 & $<, 0001$ & 0,9794 \\
\hline STR (\%) & 71,97 & 68,58 & 69,84 & 8,29 & 0,0158 & 0,3752 & $<, 0001$ & 0,1087 \\
\hline LIN (\%) & 40,45 & 37,33 & 39,40 & 8,16 & 0,0416 & 0,0950 & 0,0012 & 0,3454 \\
\hline $\mathrm{VAP}(\mu \mathrm{m} / \mathrm{s})$ & 57,70 & 55,20 & 58,87 & 14,20 & 0,7473 & 0,0894 & 0,0207 & 0,6334 \\
\hline $\operatorname{VSL}(\mu \mathrm{m} / \mathrm{s})$ & 41,34 & 37,93 & 41,11 & 11,01 & 0,2069 & 0,0595 & 0,1050 & 0,5608 \\
\hline $\operatorname{VCL}(\mu \mathrm{m} / \mathrm{s})$ & 107,92 & 109,40 & 109,89 & 23,48 & 0,5842 & 0,8326 & 0,0003 & 0,4668 \\
\hline
\end{tabular}

C1 (Contraste 1) = 0,3 ppm vs. 0,5 ppm Selênio; C2 (Contraste 2) = 0,5 ppm de Selênio inorgânico vs. 0,5 ppm de Selênio orgânico; $\mathrm{P}$ - período; $\mathrm{T} * \mathrm{P}$ - interação tratamento e período

MT - motilidade total; MP - motilidade progressiva; RAP - células rápidas; ALH - amplitude de deslocamento lateral de cabeça; BCF - frequiência de batimento; STR - retilinearidade; LIN - linearidade; VAP - velocidade de trajeto; VSL - velocidade progressiva; VCL - velocidade curvilinear.

A motilidade total reduziu com o passar dos períodos, sendo verificado diferença entre o período 0 e os períodos 48 e 72 horas.

Já para a motilidade progressiva e células rápidas notou-se um aumento até o período de 24 horas com posterior redução nos períodos subsequentes.

Em relação ao período constatou-se efeito significativo para VAP e VCL, não sendo verificado o mesmo efeito para VSL (Tabela 17). As velocidades VAP e VCL apresentaram comportamento muito semelhante, caracterizadas por um aumento até o período de 24 horas com posterior redução nos demais períodos. Foi verificado efeito de período para as 
características freqüência de batimento, amplitude de deslocamento lateral da cabeça do espermatozóide, retilinearidade e linearidade (Tabela 17).

Em relação ao BCF, houve uma redução com o passar dos períodos, sendo destacada diferença entre períodos 0 e 24 e em relação aos demais períodos

Os valores médios para a amplitude de deslocamento lateral da cabeça do espermatozóide oscilaram muito pouco, porém foi possível detectar diferenças dos períodos 0 e 48 horas comparado à 24 horas.

A retilinearidade diferiu do período 0 hora em comparação aos demais, sendo constatada uma redução gradual nos mesmos.

Os valores da linearidade se comportaram de maneira semelhante à característica retilinearidade. 
Tabela 17 - Médias \pm desvios-padrão das características de motilidade no sêmen refrigerado de cachaços em intervalos de 24 horas (Continua)

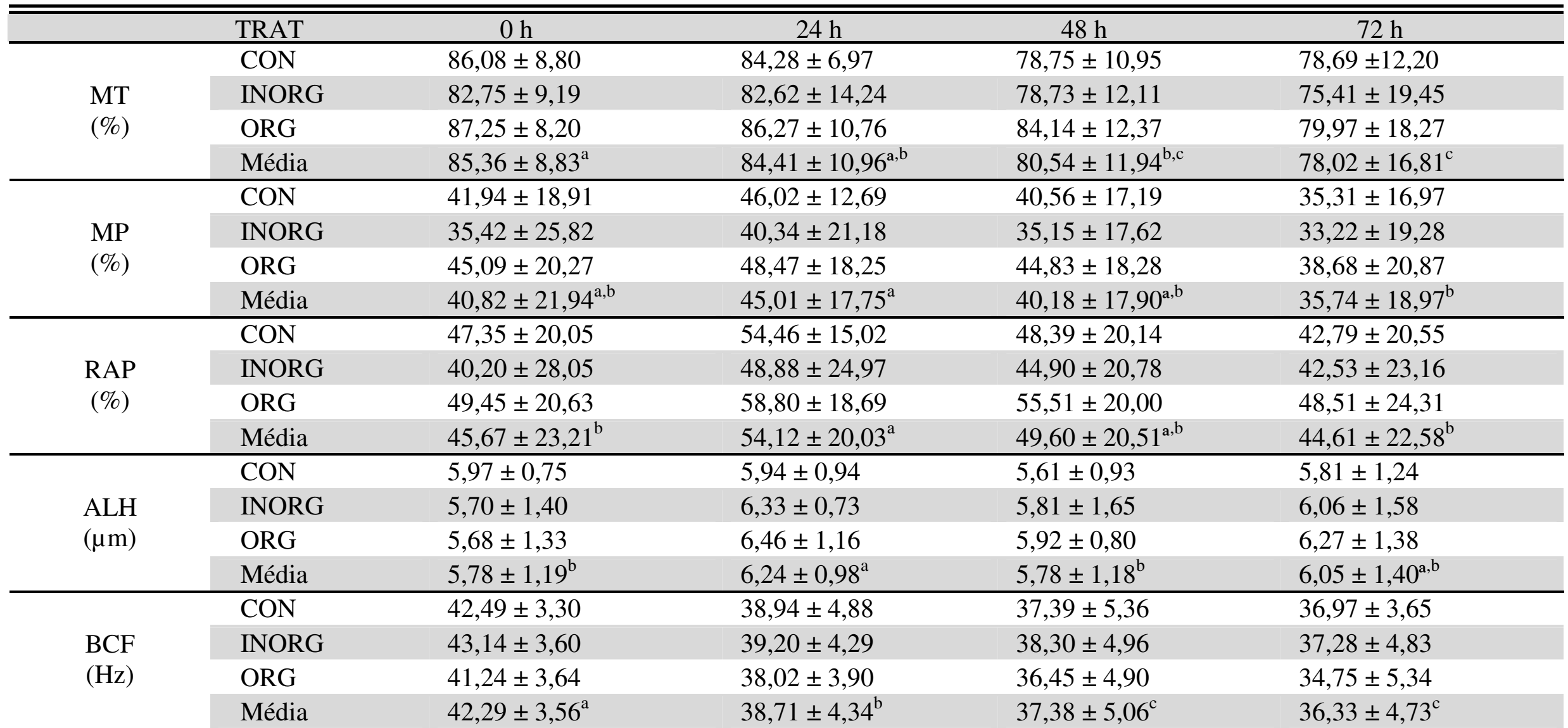

TRAT - Tratamentos; CON - Controle; INORG - Inorgânico; ORG - Orgânico; MT - motilidade total; MP - motilidade progressiva; RAP - células rápidas; ALH amplitude de deslocamento lateral de cabeça; $\mathrm{BCF}$ - frequencia de batimento;

a, b, ${ }^{c}$ Letras minúsculas diferentes na mesma linha, diferem estatisticamente $\mathrm{p}<0,05$ (teste LSD). 
Tabela 17 - Médias \pm desvios-padrão das características de motilidade no sêmen refrigerado de cachaços em intervalos de 24 horas

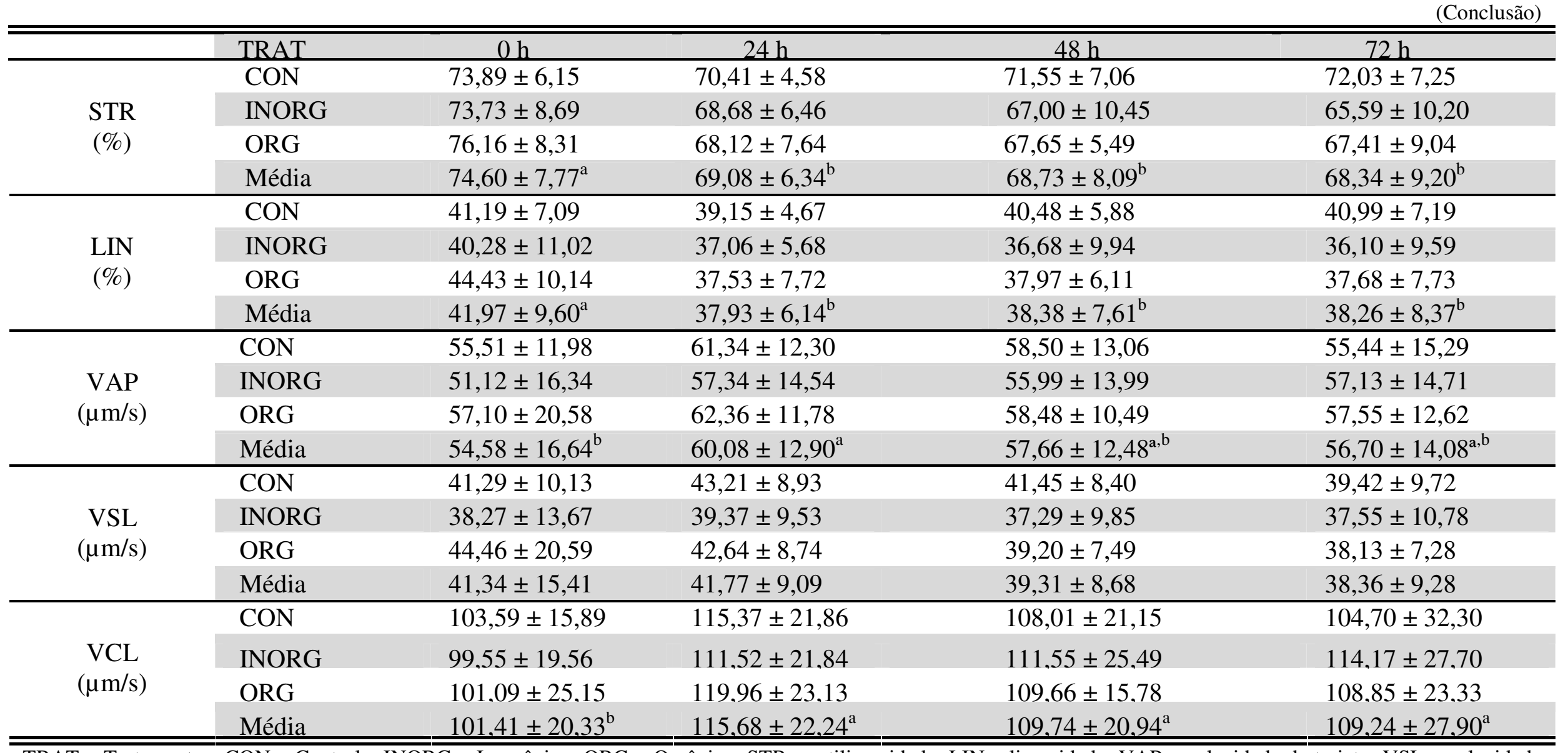

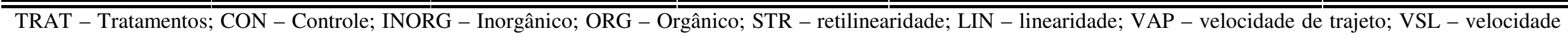
progressiva; VCL - velocidade curvilinear.

${ }^{\mathrm{a}, \mathrm{b}, \mathrm{c}}$ Letras minúsculas diferentes na mesma linha, diferem estatisticamente $\mathrm{p}<0,05$ (teste LSD). 


\subsubsection{EFEITO DO SELÊNIO NAS ANORMALIDADES MORFOLÓGICAS NO SÊMEN REFRIGERADO}

Em relação às categorias de anormalidades morfológicas não foram averiguados efeito significativo de interação (Tabela 18).

Os percentuais de células normais, com defeitos de cabeça e gota proximal foram significativamente melhores $(\mathrm{p}<0,05)$ para os cachaços que receberam selênio orgânico. Contudo, os defeitos de cauda também foram significativos para a suplementação orgânica apresentando um aumento nessa anormalidade.

Já as categorias de defeitos de cabeça, peça intermediária e gota proximal foram menores significativamente $(\mathrm{p}<0,05)$ nos cachaços suplementados, independente da fonte (Tabela 18).

Tabela 18 - Médias e desvio-padrão das anormalidades morfológicas no sêmen refrigerado de cachaços suplementados com selênio durante 72 horas

\begin{tabular}{|c|c|c|c|c|c|c|c|c|}
\hline \multirow{4}{*}{$\begin{array}{l}\text { Anormalidades } \\
\text { Morfológicas } \\
(\%)\end{array}$} & \multicolumn{8}{|c|}{ Sêmen refrigerado } \\
\hline & \multicolumn{3}{|c|}{ Tratamentos (ppm) } & \multirow{3}{*}{ DP } & \multicolumn{4}{|c|}{ Probabilidade } \\
\hline & \multicolumn{2}{|c|}{$\begin{array}{c}\text { Selênio } \\
\text { Inorgânico }\end{array}$} & \multirow{2}{*}{$\begin{array}{c}\text { Selênio } \\
\text { Orgânico } \\
0,5\end{array}$} & & \multicolumn{2}{|c|}{ Tratamento } & \multirow[t]{2}{*}{$\mathrm{P}$} & \multirow[t]{2}{*}{$\mathrm{T} * \mathrm{P}$} \\
\hline & 0,3 & 0,5 & & & $\mathrm{C} 1$ & $\mathrm{C} 2$ & & \\
\hline Normal & 79,28 & 77,45 & 84,96 & 14,71 & 0,2012 & $\mathbf{0 , 0 1 2 7}$ & $<, 0001$ & 0,3862 \\
\hline Acrossoma & 3,36 & 4,38 & 5,16 & 4,20 & 0,1099 & 0,7011 & $<, 0001$ & 0,3092 \\
\hline Cabeça & 4,64 & 5,56 & 1,97 & 4,90 & $\mathbf{0 , 0 3 5 0}$ & 0,0004 & 0,0003 & 0,5142 \\
\hline Colo & 0,78 & 1,22 & 0,68 & 1,50 & 0,5444 & 0,0658 & 0,4204 & 0,9816 \\
\hline Peça intermediária & 0,42 & 0,17 & 0,18 & 0,59 & 0,0241 & 0,8477 & 0,9816 & 0,9832 \\
\hline Cauda & 2,92 & 1,52 & 4,43 & 3,73 & 0,2975 & 0,0001 & 0,8706 & 0,8092 \\
\hline Gota proximal & 8,59 & 9,70 & 2,63 & 9,01 & 0,0052 & $<, 0001$ & 0,1345 & 0,7323 \\
\hline
\end{tabular}

C1 (Contraste 1) = 0,3 ppm vs. 0,5 ppm Selênio; C2 (Contraste 2) = 0,5 ppm de Selênio inorgânico vs. 0,5 ppm de Selênio orgânico; $\mathrm{P}$ - período; $\mathrm{T} * \mathrm{P}$ - interação tratamento e período, $\mathrm{DP}$ - desvio padrão. 
As células normais apresentaram redução $(\mathrm{p}<0,05)$ do período $0 \mathrm{~h}$ para 72 horas e as anormalidades de acrossoma e cabeça sofreram um aumento nesses percentuais (Tabela 19).

Tabela 19 - Médias \pm desvios-padrão de anormalidades morfológicas no sêmen refrigerado de cachaços durante 24 horas

\begin{tabular}{|c|c|c|c|}
\hline & TRAT & $0 \mathrm{~h}$ & $72 \mathrm{~h}$ \\
\hline \multirow{4}{*}{$\begin{array}{l}\text { Normal } \\
(\%)\end{array}$} & $\mathrm{CON}$ & $81,67 \pm 8,55$ & $76,89 \pm 9,49$ \\
\hline & INORG & $80,44 \pm 19,96$ & $74,46 \pm 20,39$ \\
\hline & $\mathrm{ORG}$ & $88,04 \pm 10,73$ & $81,87 \pm 11,75$ \\
\hline & Média & $83,38 \pm 14,19^{a}$ & $77,74 \pm 14,77^{b}$ \\
\hline \multirow{4}{*}{$\begin{array}{l}\text { Acrossoma } \\
(\%)\end{array}$} & $\mathrm{CON}$ & $1,48 \pm 1,99$ & $5,25 \pm 3,06$ \\
\hline & INORG & $1,58 \pm 1,20$ & $7,19 \pm 4,32$ \\
\hline & $\mathrm{ORG}$ & $2,17 \pm 2,87$ & $8,14 \pm 4,73$ \\
\hline & Média & $1,74 \pm 2,13^{b}$ & $6,86 \pm 4,22^{a}$ \\
\hline \multirow{4}{*}{$\begin{array}{c}\text { Cabeça } \\
(\%)\end{array}$} & $\mathrm{CON}$ & $3,64 \pm 3,47$ & $5,65 \pm 4,14$ \\
\hline & INORG & $5,04 \pm 6,58$ & $6,08 \pm 7,31$ \\
\hline & $\mathrm{ORG}$ & $1,67 \pm 1,91$ & $2,27 \pm 1,53$ \\
\hline & Média & $3,45 \pm 4,59^{b}$ & $4,67 \pm 5,16^{a}$ \\
\hline \multirow{4}{*}{$\begin{array}{l}\text { Colo } \\
(\%)\end{array}$} & $\mathrm{CON}$ & $0,62 \pm 0,90$ & $0,94 \pm 1,60$ \\
\hline & INORG & $1,31 \pm 2,17$ & $1,12 \pm 1,62$ \\
\hline & ORG & $0,67 \pm 1,47$ & $0,69 \pm 0,86$ \\
\hline & Média & $0,87 \pm 1,61$ & $0,92 \pm 1,39$ \\
\hline \multirow{4}{*}{$\begin{array}{c}\text { Peça intermediária } \\
(\%)\end{array}$} & $\mathrm{CON}$ & $0,44 \pm 0,84$ & $0,39 \pm 0,85$ \\
\hline & INORG & $0,19 \pm 0,41$ & $0,14 \pm 0,27$ \\
\hline & ORG & $0,19 \pm 0,55$ & $0,17 \pm 0,38$ \\
\hline & Média & $0,27 \pm 0,63$ & $0,24 \pm 0,57$ \\
\hline \multirow{4}{*}{$\begin{array}{c}\text { Cauda } \\
(\%)\end{array}$} & $\mathrm{CON}$ & $3,06 \pm 2,28$ & $2,77 \pm 2,23$ \\
\hline & INORG & $1,62 \pm 1,28$ & $1,42 \pm 1,55$ \\
\hline & ORG & $4,02 \pm 4,66$ & $4,83 \pm 6,45$ \\
\hline & Média & $2,90 \pm 3,20$ & $3,00 \pm 17,85$ \\
\hline \multirow{4}{*}{$\begin{array}{c}\text { Gota proximal } \\
(\%)\end{array}$} & $\mathrm{CON}$ & $9,08 \pm 7,12$ & $8,10 \pm 5,55$ \\
\hline & INORG & $9,81 \pm 12,94$ & $9,58 \pm 12,94$ \\
\hline & ORG & $3,25 \pm 4,41$ & $2,02 \pm 2,74$ \\
\hline & Média & $7,38 \pm 9,26$ & $6,57 \pm 8,80$ \\
\hline
\end{tabular}

TRAT - Tratamentos; CON - Controle; INORG - Inorgânico; ORG - Orgânico

${ }^{\mathrm{a}, \mathrm{b}, \mathrm{c}}$ Letras minúsculas diferentes na mesma linha, diferem estatisticamente $\mathrm{p}<0,05$ (teste LSD) 


\subsubsection{EFEITO DO SELÊNIO NA ATIVIDADE DA ENZIMA FOSFOLIPÍDIO HIDROPERÓXIDO GLUTATIONA PEROXIDASE (PHGPX) NO SÊMEN REFRIGERADO}

A atividade da enzima no sêmen refrigerado apresentou efeito $(\mathrm{p}<0,05)$ tanto para a suplementação de selênio, bem como para a fonte utilizada (Tabela 20). Em relação à suplementação observou-se maior atividade $18,40 \mathrm{mU} / \mathrm{mg}$ de proteína para os tratamentos com 0,5 ppm de selênio (149,90 vs. $168,30 \mathrm{mU} / \mathrm{mg}$ de proteína, 0,3 vs. 0,5 ppm de selênio, respectivamente). Já em relação ao efeito de fonte, o selênio orgânico mostrou-se superior ao selenito de sódio, 181,37 vs. $155,23 \mathrm{mU} / \mathrm{mg}$ de proteína, respectivamente (Tabela 20). Detectou-se apenas uma tendência ao efeito de interação $(\mathrm{p}<0,10)$ e não houve efeito para período $(\mathrm{p}>0,05)$.

Tabela 20 - Médias e desvios-padrão da atividade da enzima PHGPx no sêmen refrigerado de cachaços durante 72 horas

\begin{tabular}{|c|c|c|c|c|c|c|c|c|}
\hline & \multicolumn{8}{|c|}{ Sêmen Refrigerado } \\
\hline & \multicolumn{3}{|c|}{ Tratamentos (ppm) } & \multirow{3}{*}{ DP } & \multicolumn{4}{|c|}{ Probabilidade } \\
\hline & \multicolumn{2}{|c|}{$\begin{array}{c}\text { Selênio } \\
\text { Inorgânico }\end{array}$} & \multirow{2}{*}{$\begin{array}{c}\text { Selênio } \\
\text { Orgânico }\end{array}$} & & \multicolumn{2}{|c|}{ Tratamento } & \multirow[t]{2}{*}{$\mathrm{P}$} & \multirow[t]{2}{*}{$\mathrm{T}^{*} \mathrm{P}$} \\
\hline & 0,3 & 0,5 & & & $\mathrm{C} 1$ & $\mathrm{C} 2$ & & \\
\hline PHGPX & 149,90 & 155,23 & 181,37 & 51,05 & 0,0031 & 0,0003 & 0,2019 & 0,0770 \\
\hline
\end{tabular}

C1 (Contraste 1) =0,3 ppm vs. 0,5 ppm Selênio; C2 (Contraste 2) =0,5 ppm de Selênio inorgânico vs. 0,5 ppm de Selênio orgânico; $\mathrm{P}$ - período; $\mathrm{T} * \mathrm{P}$ - interação tratamento e período.

DP - desvio padrão; atividade de PHGPx - mU/mg de proteína.

Não foi evidenciado efeito de período nesta característica, o tratamento orgânico foi o que apresentou menos variação ao longo dos períodos após a diluição (Tabela 21). 
Tabela 21 - Médias \pm desvios-padrão da atividade da enzima PHGPx (mU/mg de proteína) nos espermatozóides do sêmen refrigerado de cachaços em intervalos de 24 horas

\begin{tabular}{ccccc}
\hline \hline PERÍODOS & CONTROLE & INORGÂNICO & ORGÂNICO & MÉDIA \\
\hline $0 \mathrm{~h}$ & $161,34 \pm 43,43$ & $141,80 \pm 39,37$ & $184,81 \pm 55,32$ & $162,94 \pm 49,0$ \\
$24 \mathrm{~h}$ & $139,36 \pm 43,02$ & $149,75 \pm 43,12$ & $174,48 \pm 48,04$ & $154,53 \pm 46,58$ \\
$48 \mathrm{~h}$ & $134,30 \pm 45,07$ & $168,01 \pm 57,81$ & $181,35 \pm 59,54$ & $161,22 \pm 57,33$ \\
$72 \mathrm{~h}$ & $164,62 \pm 47,97$ & $160,78 \pm 60,22$ & $184,85 \pm 39,02$ & $170,09 \pm 50,27$ \\
\hline \hline
\end{tabular}




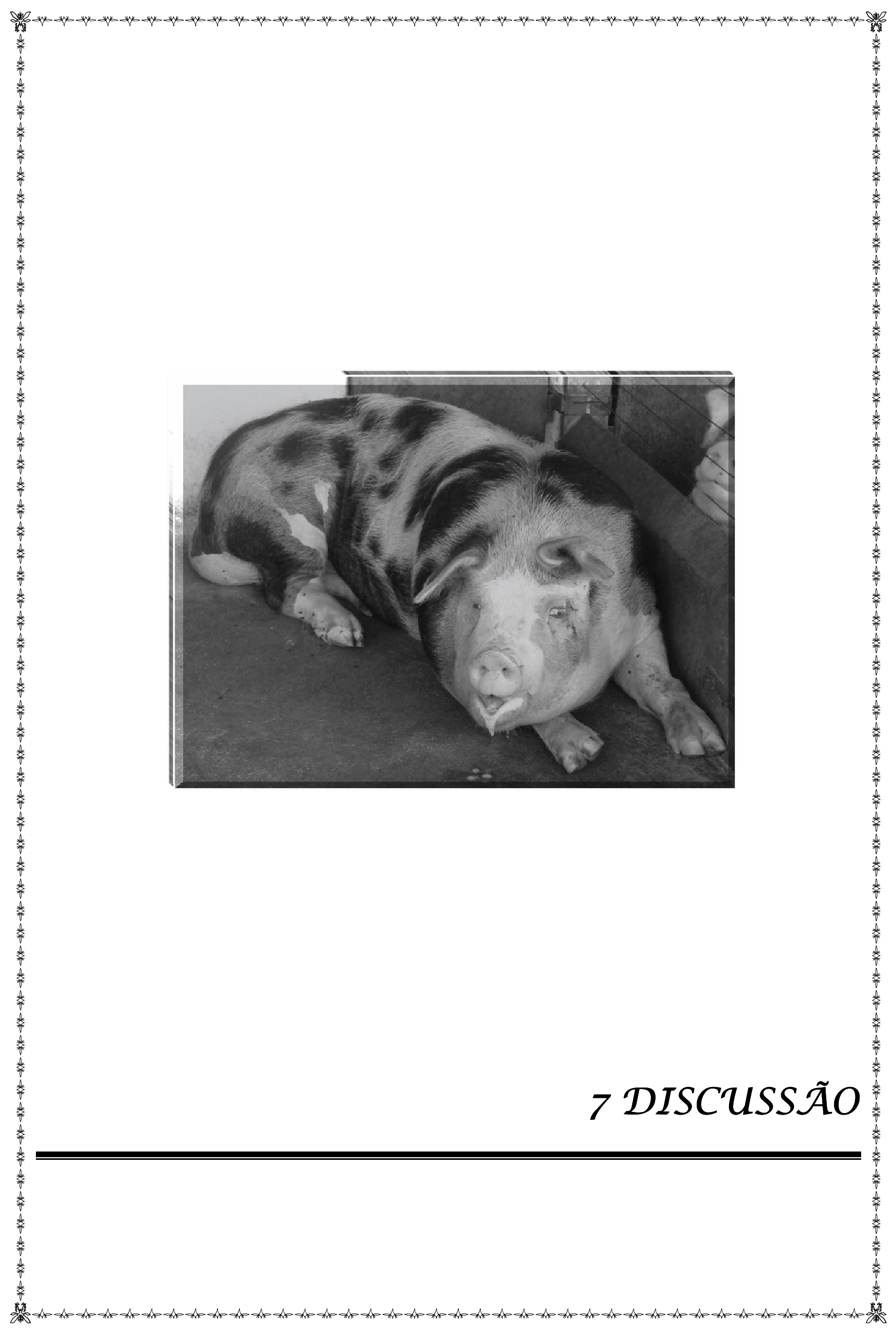




\section{DISCUSSÃO}

\subsection{SÊMEN IN NATURA}

O selênio é essencial para a fertilidade de machos, sendo necessário para a biossíntese de testosterona, formação, maturação e desenvolvimento da célula espermática (BEHNE et al., 1996; PFEIFER et al., 2001). Além disso, este mineral também parece ser fundamental para o desenvolvimento das células de Sertoli (MARIN-GUZMAN et al., 2000a) e como componente das selenoproteínas (ex. as glutationas peroxidases - GPx) (URSINI et al., 1999), as quais protegem a membrana celular contra danos oxidativos (ALVAREZ; STOREY, 1989).

A suplementação de selênio, assim como a fonte (inorgânica ou orgânica) utilizada na dieta de cachaços exerceu influências em algumas características analisadas no sêmen in natura.

Os cachaços do grupo orgânico apresentaram maior concentração espermática $(\mathrm{p}<0,05)$ e conseqüentemente maior número total de células espermáticas no ejaculado $(\mathrm{p}<0,05)$, o que originou maior número de doses inseminantes para esse grupo. Não houve diferenças $(p>0,05)$ em relação ao volume, as características de integridade das membranas acrossomal e plasmática, potencial mitocondrial e peroxidação lipídica da membrana e de motilidade espermática. Esses resultados corroboram com os achados por Jacyno; Kawecka (2002), que também verificaram maior concentração e número total de células para o tratamento orgânico, e apenas diferença numérica para a motilidade ao averiguar diferentes fontes de selênio associada à vitamina $\mathrm{E}$ na dieta de cachaços jovens, com 6 a 7 meses de idade (inorgânica - 0,2 mg de selenito de sódio e 0,3 $\mathrm{mg}$ de vitamina $\mathrm{E} / \mathrm{Kg}$ de ração e a orgânica - 0,2 mg de selênio-levedura e 0,6 mg de vitamina E/Kg de ração).

O NRC (1998) recomenda a utilização de $0,3 \mathrm{mg} / \mathrm{Kg}$ de selênio para cachaços. A semelhança nos achados por Jacyno; Kawecka (2002) utilizando a mesma fonte que o presente estudo, porém com níveis inferiores provavelmente se deve a associação com a vitamina $\mathrm{E}$ que atua sinergicamente com este mineral melhorando as características seminais.

Lopez et al. (2010), por sua vez suplementando as dietas de cachaços com 0,4 mg de selenito de sódio e $0,4 \mathrm{mg}$ de selênio orgânico, ambas combinadas com $80 \mathrm{mg}$ de vitamina 
E/Kg de ração não verificaram aumento na concentração espermática, no volume e no número total de células no ejaculado. Embora Lopez et al. (2010) tenham utilizado nível de selênio muito próximo a este estudo, os resultados obtidos por estes pesquisadores não foram semelhantes.

Em suínos, as deficiências de selênio e vitamina E tem afetado diversos aspectos reprodutivos de machos, incluindo o desenvolvimento do testículo e do próprio espermatozóide levando a conseqüências como baixa concentração espermática, reduzido percentual de motilidade e elevada incidência de gota protoplasmática proximal (LIU et al., 1982).

Um dos resultados mais interessantes deste trabalho foi o fato de ser o primeiro relato da atividade da enzima fosfolipídio hidroperóxido glutationa peroxidase (PHGPx) no espermatozóide suíno. Além disso, os resultados foram parecidos aos encontrados em animais de laboratório, humanos, touros e equinos. A técnica utilizada neste estudo foi a mesma citada para mensurar a PHGPx nas espécies descritas anteriormente, com ligeiras adaptações (MAIORINO; GREGOLIN; URSINI, 1990; GAROLLA et al., 2005).

Os cachaços que foram suplementados com selênio orgânico apresentaram maior atividade da PHGPx $(\mathrm{p}<0,05)$. Este aumento deveria promover uma redução na formação de EROs, o que favoreceria uma maior integridade de membrana das células espermáticas (URSINI et al., 1999). Contudo, neste estudo a suplementação de selênio orgânico não exerceu influência $(\mathrm{p}>0,05)$ nas características de integridade de membrana plasmática e acrossomal, potencial mitocondrial, peroxidação lipídica de membanas e motilidade espermática no sêmen in natura.

O nosso resultado vem de encontro com os achados por Castellini et al. (2002), que observaram que a suplementação de selênio na dieta aumentou a atividade da GPx nos eritrócitos e no sêmen de coelhos, porém a estabilidade oxidativa dos espermatozóides não foi detectada.

A PHGPx está presente nas células germinativas dos testículos antes do início da puberdade (PUGLISI et al., 2003) e se torna enzimaticamente ativa através da espermatocitogênese e espermiogênese (TRAMER et al., 1998; 2002). A expressão do RNA mensageiro para a PHGPx é maior nas espermátides e vai diminuindo durante o alongamento das mesmas (NAM et al., 1998).

Em mamíferos existe a PHGPx do tipo 1 até o 4 (IMAI; NAKAGAWA, 2003). Recentemente, estes autores descobriram que a PHGPx tem dupla função na célula 
espermática: (a) enzimaticamente ativa na espermátide e (b) funciona como uma proteína estrutural no espermatozóide já formado. Esta selenoproteína pode reagir com peróxido de hidrogênio e uma ampla variedade de hidroperóxidos de lipídios, sendo portanto, considerada a responsável pela proteção da membrana contra os danos oxidativos.

Nos testículos, a PHGPx encontra-se presente em três isoformas que são derivadas dos mesmos genes e localizadas no citosol, mitocôndria e núcleo, tendo a função de auxiliar no desenvolvimento dos espermatozóides por proteger contra espécies reativas ao oxigênio (BECKETT; ARTHUR, 2005).

No entanto, se extrapolarmos esse raciocínio, no espermatozóide já formado essa enzima deixa de atuar como antioxidante, reduzindo os hidroperóxidos de lipídeos na membrana e começa a agir como uma proteína estrutural, favorecendo uma melhor arquitetura da célula espemática, particularmente na peça intermediária, uma vez que compõem quase $50 \%$ do material da capsula mitocondrial (SHALINI; BANSAL, 2008).

O aumento na atividade da PHGPx no espermatozóide encontrada neste estudo foi correlacionada a maior concentração de selênio observada no plasma seminal $(r=0,27$, $\mathrm{p}=0,0209$ ). Em ambos os grupos suplementados com 0,5 ppm de selênio as concentrações no plasma sangüíneo e seminal foram maiores que o grupo controle, e dentre os suplementados a fonte orgânica foi a que se destacou com o aumento de $29 \mathrm{ng} / \mathrm{mL}$ e $5 \mathrm{ng} / \mathrm{mL}$ de selênio, no plasma sangüíneo e seminal, respectivamente.

Diversos estudos têm demonstrado que a suplementação de selênio aumenta significativamente as concentrações de selênio no sangue e a atividade das glutationas peroxidases em diversas espécies de animais e em humanos (BARTLE; SENGER; HILLERS, 1980; BUTLER et al., 1991; JOHNSSON; WESTERMARCK, 1993), sendo relatado que o selênio orgânico parece ser mais efetivo do que as formas inorgânicas (selenito ou selenato de sódio) para aumentar sua concentração no sangue (BUTLER et al., 1991; JOHNSSON; WESTERMARCK, 1993).

Em ratos, o mesmo não foi observado por Lane et al. (1979) em que o aumento nas concentrações de selênio, nem sempre foi correspondente ao aumento na atividade da GPx, indicando que esta enzima glutationa peroxidase não poderia ser usada para monitorar os níveis de selênio em ratos.

Nos estudos desenvolvidos por Iwanier; Zachara (1995), o selênio orgânico chegou ao plasma sanguíneo e seminal muito mais rápido do que a fonte inorgânica. Entretanto, o possível mecanismo apontado para este fato é que o selênio orgânico pode ser melhor 
absorvido e mais eficientemente retido do que o selenito de sódio. Essa biodisponibilidade do selênio não depende somente da absorção intestinal, mas da conversão do selênio absorvido na forma biologicamente ativa (BUTLER et al., 1991). Os minerais orgânicos são menos reativos já que utilizam as vias de absorção de moléculas orgânicas, as quais podem estar associadas aos aminoácidos, proteínas evitando que haja interação com outros minerais (MULLAN et al., 2006).

O selênio utilizado em dietas animais pode ser encontrado na forma inorgânica de selenito de sódio ou selenato de sódio e na forma orgânica como selenometionina e selenocisteína (THOMPSON; STEWART, 1973). Raras são as pesquisas que mostram a eficiência da forma selenometionina sobre o selenito de sódio. Mas, sabe-se que a selenometionina, por estar associada a aminoácidos, torna-se mais biodisponível por não apresentar cargas elétricas, favorecendo assim, sua absorção no trato gastrointestinal (WHANGER; BUTLER, 1988).

Pesquisadores têm relatado relação entre altas concentrações de selênio no plasma seminal com aumento na motilidade espermática em humanos. Todavia, na literatura há resultados contraditórios dessa relação entre concentração de selênio no plasma seminal e as características espermáticas (BLEAU et al., 1984³ apud IWANIER; ZACHARA, 1995, p. 445).

No presente estudo verificamos que o aumento na concentração de selênio no plasma seminal não interferiu $(\mathrm{p}>0,05)$ nas características de motilidade espermática, mas evidenciou-se correlação direta com o aumento nos percentuais de células normais e inversamente com os defeitos de cabeça, acrossoma, peça intermediária e gota proximal.

Garrido et al. (2004) em estudos realizados com humanos também verificaram correlação entre o aumento da PHGPx e o aumento na porcentagem de células normais, chegando a sugerirem que a PHGPx pode ser considerada um marcador bioquímico de espermatozóides morfologicamente normais.

Já os resultados encontrados por Marin-Guzman et al. (1997), utilizando a concentração de $0,50 \mathrm{ppm}$ de selênio inorgânico (selenito de sódio), sugerem que o parênquima testicular tem elevada exigência de selênio, evidenciado pelo aumento do parênquima testicular e atividade da enzima GPx. Esse selênio testicular aumentado resultou em elevada concentração de selênio na célula espermática, além de elevada atividade da

\footnotetext{
3 BLEAU, G.; LEMARBRE, J.; FAUCHER, G.; ROBERTS, K. D.; CHAPDELAINE, A. Semen selenium and human fertility. Fertility and Sterility, v. 42, p. 890-894, 1984.
} 
enzima glutationa peroxidase, sugerindo um papel funcional, além de influência na morfologia da cauda.

Dietas inadequadas para reprodutores suínos reduzem a motilidade espermática e aumentam as anormalidades morfológicas, principalmente às relacionadas à peça intermediária (mitocôndrias), havendo menor concentração de ATP e menor atividade da enzima glutationa peroxidase (GPx) (MARIN-GUZMAN et al., 1997).

Em relação a motilidade, Vyt et al. (2007) relatam que a avaliação dos parâmetros de motilidade sofrem diversas influências externas como o contato com o ar, temperatura e $\mathrm{pH}$ do diluidor. E, desta maneira a utilização da análise computadorizada do sêmen (CASA) traz vantagens comparado a avaliação subjetiva, pois além de aumentar o número de parâmetros também propicia que estes sejam melhor analisado, com acurácia e objetividade (VYT et al., 2004), permitindo que pequenas diferenças sejam percebidas.

Lopez et al. (2010) realizaram a avaliação dos parâmetros de motilidade utilizando o CASA e verificaram diferenças na velocidade progressiva, retilinearidade e linearidade favoráveis ao grupo que recebeu $0,4 \mathrm{ppm}$ de selênio levedura comparado ao controle que recebeu 0,4 ppm de selenito de sódio.

No presente estudo, por concordarmos com os autores citados acima também realizamos a averiguação da motilidade utilizando o CASA, mas no sêmen in natura não verificou-se diferenças entre os tratamentos.

Os estudos em cachaços que investigaram o mesmo nível de suplementação $(0,5 \mathrm{ppm})$, porém com fonte inorgânica, selenito de sódio, obtiveram maior atividade da enzima GPx, proporcionando melhora na motilidade (MARIN-GUZMAN et al., 1997; MARIN-GUZMAN et al., 2000a), discordando dos resultados encontrados no presente estudo, uma vez que, as motilidades total e progressiva no sêmen in natura não foram influenciadas por nenhum dos tratamentos, mesmo tendo ocorrido um aumento na PHGPx.

A maior porcentagem de motilidade (total e/ou progressiva) poderia estar diretamente envolvida na movimentação flagelar do gameta, uma vez que, foi detectado aumento na concentração de selênio na peça intermediária dos espermatozóides de ratos, previamente suplementados com este mineral por via injetável (BROWN; BURK, 1973).

O selênio ainda poderia atuar na manutenção da integridade estrutural das mitocôndrias, que refletiria na própria manutenção ou aumento da concentração de ATP nos espermatozóides proporcionando melhora na motilidade (MARIN-GUZMAN et al., 2000b). 
Vale ressaltar que, no presente estudo trabalhamos com a suplementação $(0,5 \mathrm{ppm})$ e com a recomendação do NRC (1998) 0,3 ppm e, por não serem muito distintos, algumas não foram facilmente detectadas. Alguns autores têm relatado que em situações de deficiência de selênio, moderada a severa, a motilidade e a morfologia da célula espermática são comprometidas, apresentando alterações na arquitetura da peça intermediária, resultando na separação da cabeça e cauda (SHALINI; BANSAL, 2008; WU et al., 1973).

Os efeitos já comentados anteriormente sobre as anormalidades morfológicas, favoráveis ao tratamento orgânico, corroboram com os achados por Marin-Guzman et al. (1997) que ao suplementar a dieta de cachaço com 0,5 ppm de selenito de sódio verificou maior percentual significativo de espermatozóides normais e menor percentual de gota protoplasmática proximal e de defeitos de cauda a favor do $0,5 \mathrm{ppm}$ em comparação a 0 ppm de selênio. E também com os achados por Jacyno e Kawecka (2002) que verificaram redução significativa nos percentuais de defeitos maiores e menores nos cachaços que receberam selênio orgânico associado à vitamina E.

As anormalidades na cauda do espermatozóide de ratos com deficiência de selênio tem sido relatados por Wu et al. (1973). E a associação de infertilidade e anormalidade na peça intermediária foi relatada nas células espermáticas de bovinos, sem a determinação do agente causador (COURBROUGH; BARKER, $1964^{4}$ apud WU et al., 1973). Deste modo, o selênio pode ser essencial na formação do flagelo durante a espermatogênese, ou o mineral pode ser importante para a qualidade da membrana que envolve os filamentos axiais.

Segundo Buchanan-Smith et al. (1969), carneiros com deficiência de selênio apresentam diminuição na estabilidade de lisossomos nas células do fígado. Um caminho apontado pelo próprio autor verificado em ratos com deficiência deste mineral é que pode ocorrer lise dos lisossomos na célula espermatogênica e que estas enzimas lisossomais podem danificar as membranas da cauda do espermatozóide.

\footnotetext{
${ }^{4}$ COURBROUGH, R.J.; BAKER, C.A.V. Spermatozoa: An unusual middlepiece abnormality associated with sterility in bulls. In: $\mathbf{5}^{\text {th }}$ International Congress Animal Reproduction, n. 4, p. 219, 1964.
} 


\subsection{SÊMEN REFRIGERADO}

Durante o armazenamento do sêmen suíno sob refrigeração entre 17 a $19^{\circ} \mathrm{C}$, pelo período de 3 a 7 dias, a capacidade de organização da membrana da célula espermática em responder ao processo de refrigeração é prejudicada pela sua incapacidade de alterar a fluidez da membrana, que por sua vez, está relacionada com a integridade e mudanças na composição lipídica da membrana plasmática (CEROLINI et al., 2000; WABERSKI et al., 1994).

Um importante indicador de membrana lesada do espermatozóide durante a refrigeração é a mudança na permeabilidade da membrana, tais como permeabilidade aumentada para corantes e liberação de substâncias intracelulares. Em relação a esta permeabilidade, a distinção deve ser feita entre a membrana acrossomal e plasmática do espermatozóide. A perda de elétrons também é um indicativo do processo de envelhecimento da célula espermática. Isto poderia ser causado pela peroxidação lipídica devido à alta quantidade de ácidos graxos poliinsaturados na membrana espermática dos cachaços, o qual poderia alterar a composição lipídica da membrana. Estas mudanças são balanceadas pela ação protetora dos antioxidantes superóxido desmutase e glutationa peroxidase no sêmen (DE LAMIRANDE; GAGNON, 1992).

O aumento na peroxidação das membranas ocorre normalmente durante a refrigeração, levando a alterações tanto na integridade como na morfologia do espermatozóide (SURAI et al., 1998). A formação das EROS basal e a peroxidação da membrana lipídica foram muito baixos nos espermatozóides viáveis no sêmen in natura e refrigerado de cachaços (GUTHRIE et al., 2008). Isto é importante, porque nem todas as células são dotadas de enzimas que combatem as EROS (STOREY, 1997). Teoricamente, os dois primeiros pontos do sistema de defesa celular contra as EROS são a dismutação e então as enzimas catalase e glutationa peroxidase para catalizar redução do peróxido de hidrogênio (AITKEN, 1995). Baseado nos baixos níveis de formação de EROS e peroxidação da membrana lipídica, o sistema endógeno de defesa no sêmen de cachaços é pouco eficiente indicando um baixo nível de formação de ânion superóxido mitocondrial ou atividade enzimática suficiente para neutralizar o ânion superóxido e o peróxido de hidrogênio (GUTHRIE et al., 2008).

A utilização de alguns diluidores pode induzir a capacitação espermática possivelmente seguida de reação acrossomal (VISHWANATH; SHANNON, 1997). A diminuição na integridade do acrossoma pode ser devido à reação acrossômica em adição a 
lesão na membrana. Quando avaliamos a qualidade do sêmen durante a refrigeração não deveria se colocada tanta ênfase apenas na motilidade, mas também deve ser dada atenção para outras características de qualidade que podem ser utilizadas na averiguação da capacidade fertilizante (LARSSON; EINARSSON, 1976), como por exemplo a integridade das membranas.

Ao avaliarmos a ação do selênio orgânico observamos que houve reduções $(p>0,05)$ nos percentuais de células com membrana acrossomal e plasmática íntegra e potencial mitocondrial com o aumento do tempo de refrigeração. Contudo, o resultado de potencial mitocondrial não foi o esperado, uma vez que a maior quantidade de selênio no plasma seminal aumenta a atividade do fosfolipídio hidroperóxido glutationa peroxidase, incrementando o potencial das mitocôndrias, ou melhor, a concentração de ATP na peça intermediária da célula espermática, o que levaria a melhora na motilidade espermática.

As células AIMI diferiram dos achados por outros pesquisadores, que ao avaliarem a integridade de membrana com a associação de SYBR-14 e iodeto de propídio no ejaculado suíno diluído em BTS, verificaram um aumento nestes percentuais 24 horas após a diluição e a partir deste período um declínio nessa variável (DE AMBROGI et al., 2006).

No entanto, ao suplementarem perus com 0,3 ppm de selênio orgânico (Sel-Plex ${ }^{\mathrm{TM}}$ ), foram observadas reduções significativas no percentual de espermatozóides vivos em seis horas após a diluição, através da técnica da eosina-nigrosina, ou seja, a suplementação não auxiliou na manutenção da integridade das células espermáticas após a diluição (DIMITROV et al., 2007). Resultado este, que confirma os achados do presente estudo, embora a técnica utilizada seja subjetiva podendo ocorrer falhas na interpretação dos resultados.

Sarlós et al. (2002); Alvarez; Moraes (2006) avaliaram o efeito de vários antioxidantes no sêmen de carneiros, entre eles, a glutationa peroxidase, e observaram que a adição de antioxidante prolonga o período de conservação do sêmen, melhorando a motilidade e reduzindo o grau de danos celulares nos espermatozóides, o que de certa forma vem de encontro aos resultados esperados neste estudo.

Por outro lado, em relação às anormalidades morfológicas da célula espermáticas os cachaços do tratamento orgânico apresentaram maior porcentagem $(p<0,05)$ de formas normais e reduções $(\mathrm{p}<0,05)$ nos defeitos de cabeça e gota protoplasmática proximal, além da suplementação ter diminuído os defeitos na peça intermediária.

Diversos estudos têm demonstrado que a falha no destacamento da gota citoplasmática durante a espermiação está associada com o aumento na produção de EROs (GIL-GUZMAN 
et al., 2001). O percentual de gota protoplasmática proximal nos espermatozóides dos cachaços do tratamento orgânico em comparação ao controle e inorgânico foram de 2,63\% vs $8,59 \%$ e 9,70\%, respectivamente. Mesmo assim, não houve uma menor peroxidação das membranas no grupo suplementado com selênio orgânico.

Em relação as características de motilidade total e progressiva verificou-se efeito $(\mathrm{p}<0,05)$ benéfico do selênio orgânico, uma vez que, os animais que receberam esse tratamento apresentaram aumento em ambas as motilidades. Em relação ao período, as motilidades total e progressiva apresentaram redução mais acentuada a partir de 48 horas após a diluição. Este resultado já era esperado, uma vez que, que o espermatozóide de mamíferos responde à diluição com um aumento inicial de atividade, seguido pela perda de motilidade e aumento de lesão na membrana (JOHNSON et al., 2000), estes resultados estão de acordo com os achados por (DIMITROV et al., 2007).

Essa melhora na motilidade total e progressiva corrobora com os encontrados por outros autores, que constataram resposta semelhante ao nosso estudo ao avaliarem o ejaculado suíno diluído em BTS por até 96 horas. Este aumento na motilidade pode ser devido à maior absorção de selênio que se deposita principalmente na peça intermediária auxiliando na manutenção da estrutura das mitocôndrias, contribuindo na produção de ATP e conseqüentemente na motilidade (DE AMBROGI et al., 2006).

A redução da motilidade, o qual ocorre durante a refrigeração tem sido o principal parâmetro usado para julgar a diminuição da capacidade fertilizante. A perda de ATP e AMPc, bem como o transporte reduzido de cálcio são características de motilidade reduzida (JOHNSON et al., 2000). A motilidade progressiva do espermatozóide é um indicador tanto do metabolismo sem prejuízos como da integridade da membrana. A motilidade, portanto, é importante para o controle diário da qualidade do sêmen. O espermatozóide de cachaços apresenta maior percentual de movimento circular em comparação com outras espécies, e deste modo, é recomendado estimar as diferentes formas de motilidade, incluindo os percentuais de motilidade progressiva (JOHNSON et al., 2000).

Outras características como a linearidade e a retilinearidade apresentaram efeito $(\mathrm{p}<0,05)$ favorável a utilização de $0,3 \mathrm{ppm}$ de selenito de sódio, no sentido de que os animais apresentaram maiores valores percentuais em ambas características em comparação a suplementação de 0,5 ppm de selênio, independente do tipo de fonte. Estas características estão relacionadas com a hiperativação das células que podem ter ocorrido devido ao processo de refrigeração, porém esta hiperativação acontecendo antes de entrar no trato reprodutivo da 
fêmea não é interessante. Ou seja, se a suplementação reduziu estas características, na realidade houve um prejuízo na capacidade fertilizante dos espermatozóides.

As velocidades de trajeto e progressiva aumentaram no sêmen dos animais que receberam a suplementação de selênio orgânico em comparação à fonte inorgânica. Esse aumento poderia ser devido à maior quantidade de selênio absorvido, que por sua vez, atuaria na manutenção da integridade das mitocôndrias que pode ter possibilitado a maior concentração de ATP, favorecendo então o aumento dessas velocidades.

Em estudos desenvolvidos em humanos, utilizando a suplementação de selênio orgânico, os resultados mostraram-se contraditórios aos obtidos em nossa pesquisa, pois não houve efeito significativo para nenhum das características de motilidade (porcentagem de espermatozóides móveis, amplitude de deslocamento lateral de cabeça, freqüência de batimento, retilinearidade, linearidade, velocidade de trajeto, velocidade progressiva e velocidade curvilinear (HAWKES et al., 2009)).

A atividade da fosfolipídio hidroperóxido glutationa peroxidase no espermatozóide suíno durante a refrigeração foi descrita pela primeira vez neste estudo. A PHGPx foi maior $(\mathrm{p}<0,05)$ no grupo orgânico comparado aos demais, demonstrando que o aumento na concentração de selênio leva a maior produção da PHGPx. Em relação ao período de refrigeração observou-se que não houve uma redução em sua atividade. Este fato sugere que a PHGPx realmente pode estar atuando como uma proteína estrutural e não como uma enzima antioxidante, o que corrobora com os relatos de Foresta et al. (2002) e Stradaioli et al. (2009) que analisaram a PHGPx no sêmen in natura de humanos e touros, respectivamente.

A forma de suplementação dos minerais é de extrema importância, pois esse fator pode diferenciar a quantidade absorvida e, portanto, a quantidade do mineral que estará disponível para ser utilizado pelo organismo. Autores relataram que houve um decréscimo no percentual de anormalidades morfológicas quando da utilização do selênio orgânico, demonstrando que a forma orgânica foi muito mais eficaz do que o selenito de sódio (DIMITROV et al., 2007).

Diante do exposto, sugere-se que a suplementação de selênio orgânico na dieta de cachaços é benéfica para algumas características espermáticas seja no sêmen in natura ou refrigerado a $18^{\circ} \mathrm{C}$ por 72 horas. 


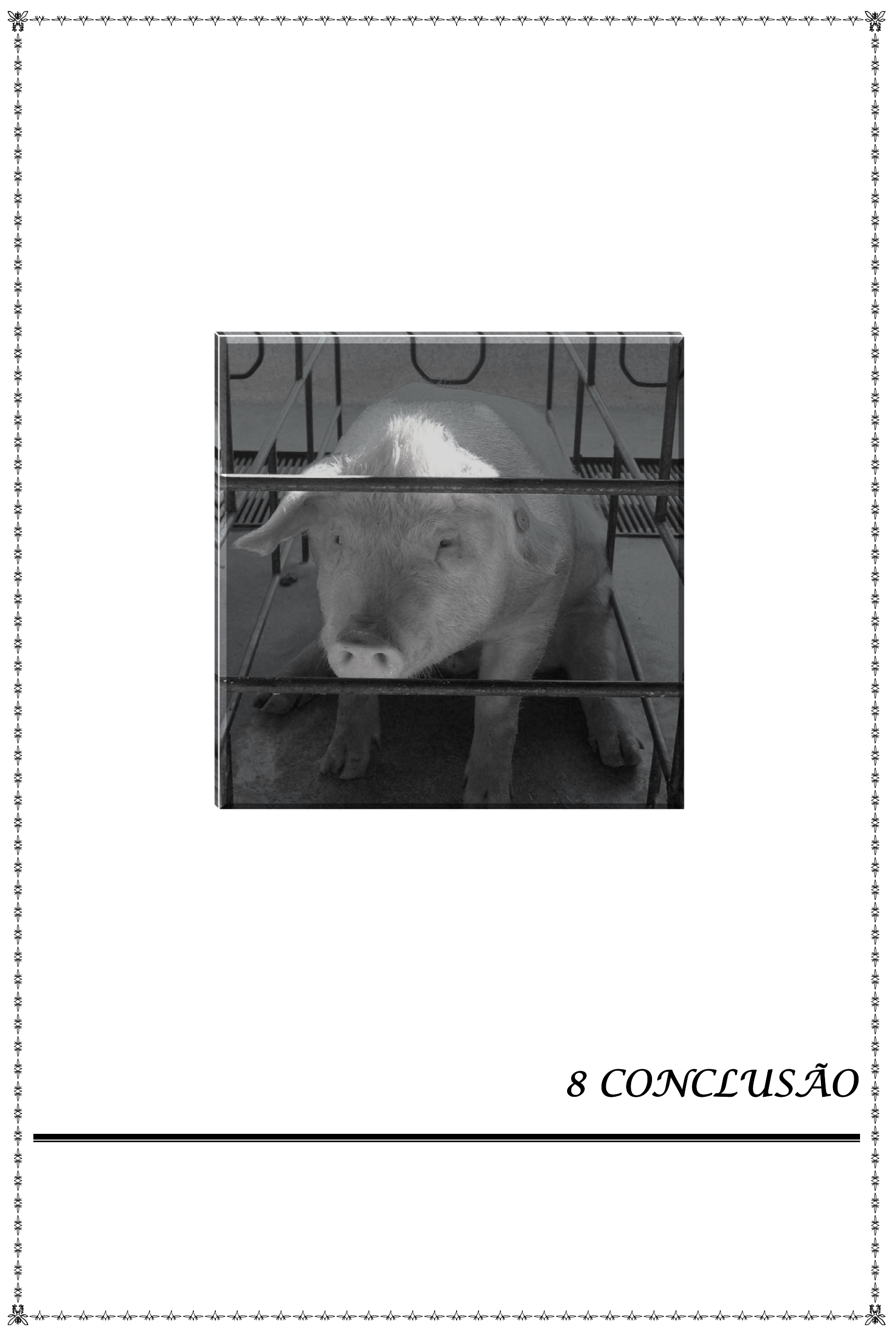




\section{CONCLUSÃO}

A partir dos resultados obtidos pudemos concluir:

1. A suplementação oral de selênio levedura (orgânico) melhorou a concentração espermática o número total de células e aumentou o número de doses inseminantes no sêmen in natura.

2. Os cachaços alimentados com selênio levedura (orgânico) apresentaram maior concentração de selênio no plasma sangüíneo e seminal em comparação aos animais que foram alimentados com selenito de sódio (inorgânico).

3. A maior concentração de selênio no plasma seminal aumentou a atividade da enzima fosfolipídio hidroperóxido glutationa peroxidase no espermatozóide suíno, levando a maiores percentuais de células normais e redução dos defeitos de acrossoma, cabeça, peça intermediária e gota proximal no sêmen in natura cachaços.

4. Os cachaços suplementados com selênio levedura mantiveram normais as características de motilidade espermática no sêmen refrigerado no decorrer do tempo (0, 24, 48 e 72 horas após a diluição).

5. O aumento da atividade da enzima fosfolipídio hidroperóxido glutationa peroxidase na célula espermática de cachaços não melhorou as integridades de membrana plasmática e acrossomal, potencial de membrana mitocondrial e também não reduziu a peroxidação lipídica das membranas espermáticas no sêmen in natura e refrigerado.

6. Os cachaços suplementados com selênio levedura tiveram um aumento na atividade da enzima fosfolipídio hidroperóxido glutationa peroxidase no espermatozóide suíno favorecendo a manutenção dos maiores percentuais de células normais e redução dos defeitos de cabeça e gota proximal no sêmen refrigerado cachaços. 


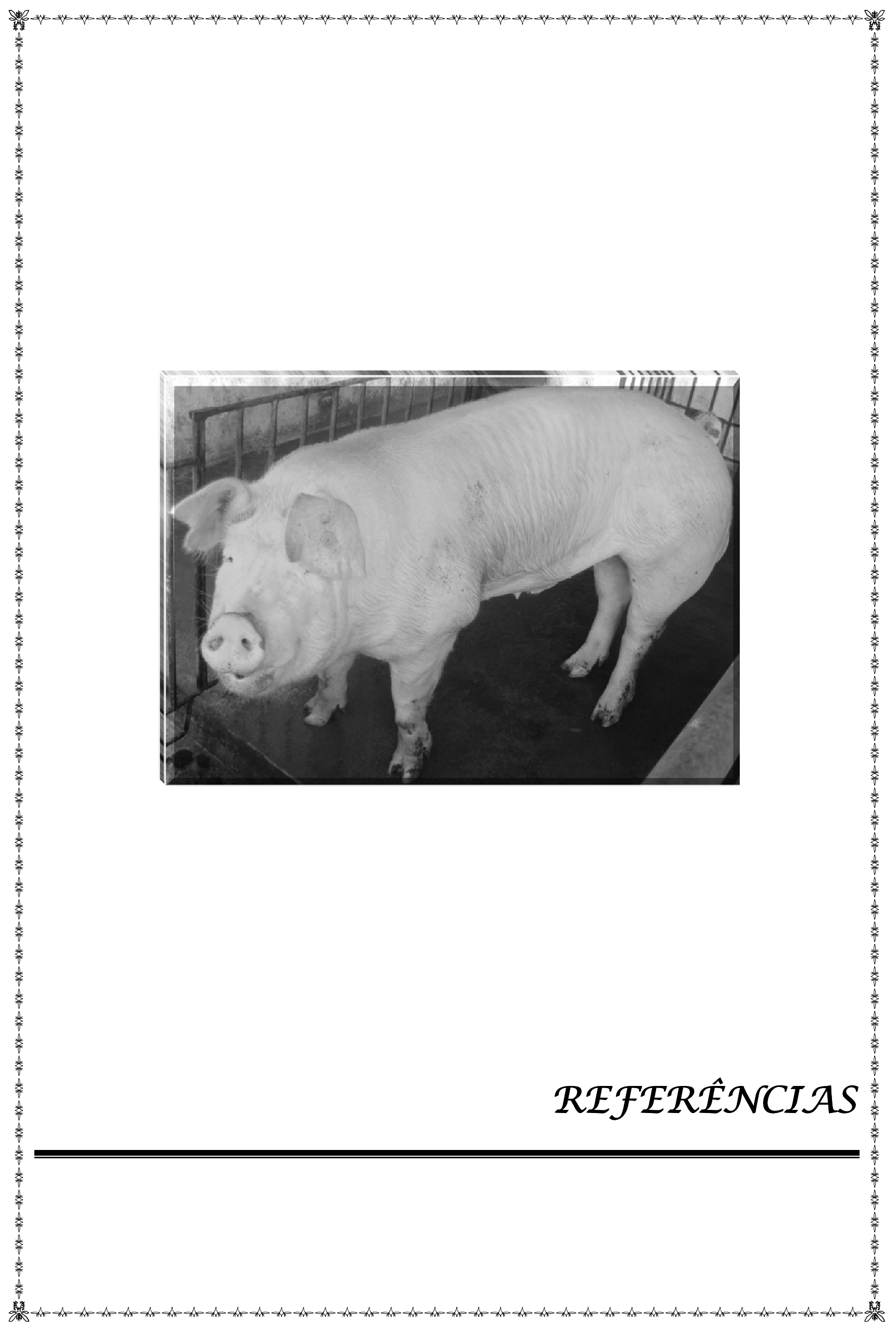




\section{REFERÊNCIAS}

AITKEN, R. J. Free radicals, lipid peroxidation and sperm function. Reproduction, Fertility and Development, v. 7, p. 659-668, 1995

AITKEN, R. J.; CLARKSON, J. S. Cellular basis of defective sperm function and its association with the genesis of reactive oxygen species by human spermatozoa, Journal Reproduction and Fertility, v.81, p.459-469, 1987.

AITKEN, R. J.; CLARKSON, J. S.; FISHEL, S. Generation of reactive oxygen species, lipid peroxidation, and human sperm function, Biology of Reproduction, v. 40, p. 183-197, 1989.

AITKEN, R. J.; FISHER, H. Reactive oxygen speciesgeneration and human spermatozoa: the balance of benefit and risk, Bioassays, v. 16, p. 259-267, 1994.

ALVAREZ, J. G., STOREY, B. T. Role of glutathione peroxidase in protecting mammalian spermatozoa from loss of motility caused by spontaneous lipid peroxidation. Gamete Research. v. 23, p. 77-90, 1989.

ALVAREZ, C. A.; MORAES, G. V. Efeitos da selenometionina e vitamina C sobre o sêmen. SaBios: Revista Saúde e Biologia, v. 1, n. 1 p. 42-51, 2006.

ARRUDA, R. P. Avaliação dos efeitos de diluidores e crioprotetores para o espermatozóide eqüino pelo uso de microscopia de epifluorescência, citometria de fluxo, análises computadorizadas da motilidade (CASA) e da morfometria (ASMA). 121 p. Tese (Livre Docência) - Faculdade de Medicina Veterinária e Zootecnia, Universidade de São Paulo, Departamento de Reprodução Animal, Pirassununga, 2000.

BALL, B. A.; VO, A. Detection of lipid peroxidation in equine spermatozoa based upon the lipophilic fluorescent dye $\mathrm{C}_{11}$ - BODIPY ${ }^{581 / 591}$, Journal of Andrology, v. 23, n. 2, p. 259-269, 2002.

BARTLE, J. L.; SENGER, P. L.; HILLERS, J. K. Influence of injected selenium in dairy bulls on blood and semen selenium, glutathione peroxidase and seminal quality. Biology of reproduction, v. 23, p. 1007-1013, 1980.

BECKETT, G.J.; ARTHUR, J.R. Selenium and endocrine systems. Journal of Endocrinology, s.L., v.184, p.455-465, 2005.

BEHNE, D., WEILER, H.; KYRIAKOPOULOS, D A. Effects of selenium deficiency on testicular morphology and function in rats. Journal Reproduction and Fertility, v. 106, p. 291-297, 1996.

BERTELSMANN, H.; SIEME, H.; BEHNE, D.; KYRIAKOPOULOS, A. Is the distribution of selenium and zinc in the sublocations of spermatozoa regulated? Annals of the New York Academy of Sciences, v. 1095, p. 204-208, 2007. 
BRADFORD, M. M. A rapid and sensitive method for the quantitation of microgram quantities of protein utilizing the principle of protein-dye binding. Analytical Biochemistry, v. 72, p. 248-254, 1976.

BRODY, T. Nutritional Biochemistry. Academic Press: Inc. New York, 1994. 658 p.

BROUWERS, J. F.; GADELLA, B. M. In situ detection and localization of lipid peroxidation in individual bovine sperm cells, Free Radical Biology \& Medicine, v. 35, p. 1382-1391, 2003.

BROWN, D.G.; BURK, R.F. Selenium retention intissues and sperm of rats fed a Torula yeast diet. Journal of Nutrition, v. 102, p. 102-108, 1973.

BUCHANAN-SMITH, J.G.; NELSON, E.C.; TILLMAN, A.D. Effect of vitamin E and selenium deficiencies on lyosomal and cytoplasmatic enzymes. Journal of Nutrition, v. 99, p. 387, 1969.

BUTlER, J. A.; THOMSON, C. D.; WHANGER, P. D.; ROBINSON, M. F. Selenium distribution in blood fractions of New Zealand women taking organic or inorganic selenium. American Journal of Clinical Nutrition, v. 53, p. 748-754, 1991.

CALVIN, H. I.; COOPER, G. W.; WALLACE, E. Evidence that selenium in rat sperm is associated with a cysteine-rich structural protein of the mitochondrial capsules. Gamete Research, v. 4, p. 139-149, 1981.

CASTELlinI, C.; LATTAIOLI, P.; DAL BOSCO, A.; BEGHELLI, D. Effect of supranutritional level of dietary alpha-tocopheryl acetate and selenium on rabbit semen. Theriogenology, v. 58, p. 1723-1732, 2002.

CELEGHINI, E. C.; ARRUDA, R. P.; DE ANDRADE, A.F.C.; NASCIMENTO, J.; RAPHAEL, C.F. Practical techniques for bovine sperm simultaneous fluorimetric assessment of plasma, acrosomal and mitochondrial membranes. Reproduction in Domestic Animals, v. 42, p. 479-488, 2007.

CEROLINI, S.; ARRUDA, R. P.; DE ANDRADE, A.F.C.; NASCIMENTO, J.; RAPHAEL, C.F. Viability, susceptibility to peroxidation and fatty acid composition of boar semen during liquid storage. Animal Reproduction Science, v. 58, p. 99-111, 2000.

COLÉGIO BRASILEIRO DE REPRODUÇÃO ANIMAL - CBRA. (1998). Manual para exame andrológico e avaliação de sêmen animal. (CBRA: Belo Horizonte).

CORRÊA, M. N.; MEINCKE, W.; LUCIA Jr, T.; DESCHAMPS, J. C. Processamento do sêmen. In: . Inseminação artificial em suínos. Pelotas: Printpar, 2001. cap. 5, p. 85121.

CLOSE, W. H. The role of trace mineral proteinates in pig nutrition. In: LYONS, T. P., JACQUES, K. A. Biotechnology in the Feed Industry. Nottingham University Press: United Kingdom, 1998. p. 469-483.

CLOSE, W. H.; COLE, D. J. A. The boar. In: Nutrition of Sows and Boars. Nottingham University Press: United Kingdom, 2000. cap. 11, p. 257-291. 
DANIELS, L. A. Selenium metabolism and bioavailability. Biological Trace Element Research, v. 54, n. 3, p. 185-199, 1996.

DE AMBROGI, M.; BALLESTER, J.; SARAVIA, F.; CABALLERO, I.; JOHANNISSON, A.; WALLGREN, M.; ANDERSSON, M.; RODRIGUEZ-MARTINEZS, H. Effect of storage in short-and long-term commercial semen extenders on the motility, plasma membrane and chromatin integrity of boar spermatozoa. International Journal of Andrology, v. 29, p. 543$552,2006$.

DE ANDRADE, A. F. C.; ARRUDA, R. P.; CELEGHINI, E. C. C.; NASCIMENTO, J.; MARTINS, S. M. M. K.; RAPHAEL, C. F.; MORETTI, A. S. Fluorescent stain method for the simultaneous determination of mitochondrial potential and integrity of plasma and acrosomal membranes in boar sperm. Reproduction in Domestic Animals, v. 42, n. 2, p. 190-194, 2007.

DE LAMIRANDE, E.; GAGNONS, C. Reactive oxygen species and human spermatozoa. I. Effects on the motility of intact spermatozoa and on sperm axonemes. Journal of Andrology, v. 13, p. 368-378, 1992.

DIMITROV, S. G., ATANASOV, SURAI, P. F; DENEV, S. A. Effect of organic selenium on turkey semen quality during liquid storage. Animal Reproduction Science, v. 100, p. 311$317,2007$.

ENSMINGER, M.E., OLDFIELD, J.E. Feeds \& Nutrition. 2 ed. Califórnia: Ensminger Publishing Company, 1990. 500p.

FAIRWEATHER-TAIT, S. J. Bioavailability of dietary minerals. Biochemical Society Transactions, v. 24, p. 775-780, 1996.

FAIRWEATHER-TAIT, S. J. Bioavailability of trace elements. Food Chemistry, v. 43, p. 213-217, 1992.

FERREIRA, A. L. A.; MATSUBARA, L.S. Radicais livres: conceitos, doenças relacionadas, sistema de defesa e estresse oxidativo. Revista da Associação Médica Brasileira, v. 43, p. 61-68, 1997.

FORBES, R. M.; ERDMAN, J. W. Bioavailability of trace mineral elements. Annual Review of Nutrition, v. 3, p. 213-231, 1983.

FORESTA, C.; FlOHÉ, L.; GAROLlA, A.; ROVER, A.; URSINI, F.; MAIORINO, M. Male fertility is linked to the seleprotein in phospholipid hidroperoxide glutathione peroxidase. Biology of Reproduction, v. 67, p. 967-971, 2002.

FRANCESCONI, K. A.; PANNIER, F. Selenium metabolites in urine: a critical overview of past work and current status. Clinical Chemistry, v. 50, p. 2240-2253, 2004.

GAROLLA, A.; MAIORINO, M.; ROVERATO, A.; ROVERI, A.; URSINI, F.; FORESTA, C. Oral carnitine supplementation increases sperm motility in asthenozoospermic men with normal sperm phospholipid hydroperoxide gluthatione peroxidase levels. Fertility and Sterility, v. 83, n. 2, p. 355-361, 2005. 
GARRIDO, N.; MESEGUER, M.; JUAN ALVAREZ, M. D.; CARLOS SIMÓN, M. D.; ANTONIO PELLICER, M. D.; JOSÉ REMOHÍ, M. D. Relationship among standard semen parameters, glutathione peroxidase/glutathione reductase activity, and mRNA expression and reduced glutathione content in ejaculated spermatozoa from fertile and infertile men. Fertility and Sterility, v. 82, p. 1059-1066, 2004.

GIL-GUZMAN, E.; OLLERO, M.; LOPEZ, M.C.; SHARMA, R.K.; ALVAREZ, J.G.; THOMAS, A.J. JR; AGARWAL, A. Differential production of reactive oxygen species by subsets of human spermatozoa at different stages of maturation. Human Reproduction, $v$. 16, p. 1922-1930, 2001.

GOMEZ, E.; IRVINE, D. S.; AITKEN, R. J. Evaluation of a spectrophotometric assay for the measurement of malondialdehyde and 4-hydroxyalkenals in human spermatozoa: relationships with semen quality and sperm function, International Journal of Andrology, v. 21, p. 81-94, 1998.

GOULD, T. C. Incorporation of minerals in spermatogenic pathway. Journal of Andrology, v. 1, p. $56-58,1970$.

GUTHRIE, H. D.; WELCH, G. R.; LONGS, J. A. Mitochondrial function and reactive oxygen species action in relation to boar motility. Theriogenology, v. 70, p. 1209-1215, 2008.

HAWKES, W. C., ALKAN, Z.; WONG, K. Selenium supplementation does not affect testicular selenium status or semen quality in north american men. Journal of Andrology, v. 30, p. 525-533, 2009.

HERRICK, J.B. Mineral in animal health. In: ASHMEAD, H.D. (Ed.). The roles of amino acid chelates in animal nutrition. New Jersey: Noyes, 1993. p. 3-9.

HYNE, M. J.; KELLY, P. Metal ions, chelates and proteinates. In: Biotechnology in the feed industry. Loughborough, Leics, United Kingdom: Nottingham University Press, 1995. p. 233-248.

IMAI, H.; NAKAGAWA, Y. Biological significance of phospholipids hydroperoxide gluthathione peroxidase (PHGPx, GPx 4) in mammalian cells. Free Radical Biology \& Medicine, v. 34, n. 2, p. 145-169, 2003.

IMAI, H.; SUZUKI, K.; ISHIZAKA, K.; ICHINOSE, S.; OSHIMA, H.; OKAYASU, I.; EMOTO, K.; UMEDA, M.; NAKAGAWA, Y. Failure of the expression of phospholipid hydroperoxide glutathione peroxidase in the spermatozoa of human infertile males. Biology of Reproduction, v. 64, p. 674-683, 2001.

IWANIER, K.; ZACHARA, B. A. Selenium supplementation enhances the element concentration in blood and seminal fluid but does not change the spermatozoal quality characteristics in subfertile men. Journal of Andrology, v. 16, n. 5, p. 441-447, 1995.

JACYNO, E.; KAWECKAS, M. Influence of inorganic se + vitamin e and organic se + vitamin e on reproductive performance of young boars. Agricultural and Food Science in Finland, v. 11, p. 175-184, 2002. 
JOHNSON, L. A., WEITZE, K. F.; FISER, P.; MAXWELLS, W. M. Storage of boar semen. Animal Reproduction Science, v. 62, p. 143-172, 2000.

JOHNSSON E.; WESTERMARCK, T. Studies of selenium supplementation with inorganic and combined inorganic-organic Se in humans. Journal of Trace Elements and Electrolytes in Health and Disease, v. 7, p. 113-114, 1993.

KIEFER, C. Minerais quelatados na nutrição de aves e suínos. Revista Eletrônica Nutritime, v. 2, n. 3, p. 206-220, 2005.

KING, G. J.; MACPHERSON, J. W. A comparison of two methods for boar sêmen collection. Journal of Animal Science, v. 36, n. 4, p. 563-565, 1973.

KRATZER, F. H., VOHRA, P. Chelates and chelation. In: KRATZER, F.H., VOHRA, P. Chelates in nutrition. Boca Raton, Florida: CRC Press, p.5-33. 1996.

KRYUKOV, R.; CASTELLANO, S.; NOVOSELOV, S. V.; LOBANOV, A. V.; ZAHTAB, O.; GUIGO, R.; GLADYSHEV, V. N. Characterization of mammalian selenoproteomes. Science, v. 300, p. 1439-1443, 2003.

LANE, H. W.; SHIRLEY, R. L.; CERDA, J. J. Glutathione peroxidase activity in intestinal and liver tissues of rats fed various levels of selenium, sulfur and $\alpha$-tocopherol. Journal of Nutrition, v. 109, p. 444-452, 1979.

LARSSON, K., EINARSSON, S. Influence of boars on the relationship between fertility and post thawing sperm quality of deep frozen boar spermatozoa. Acta Veterinaria Scandinavica, v. 17, p. 74-82, 1976.

LEESON, S., SUMMERS, J. D. Commercial poultry nutrition. 2 ed. Guelph, Ontario: University Books, 1997. p. 57-58.

LEESON, S., SUMMERS, J. D. Nutrition of the chicken. 4 ed. Guelph, Ontario: University Books, 2001. 591p.

LIU, C. H.; CHEN, Y. M.; ZHANG, J. Z.; HUANG, M. Y.; SU, Q.; LU, Z. H.; YIN, R. X.; SHAO, G. Z.; FENG, D.; ZHENG, P. L. Preliminary studies on influence of selenium deficiency to the developments of genital organs and spermatogenesis of infancy boars. Acta Veterinaria et Zootechnica Sinica, v. 13, p. 73-77, 1982.

LOPEZ, A.; RIJSSELARE, T.; VAN-SOOM, A.; LEROY, J. L. M. R.; DE CLERCQ, J. B. P.; BOLS, P. E. J.; MAES, D. Effect of organic selenium in the diet on sperm quality of boars. Reproduction in Domestic Animals, v.45, p.e297-2305, 2010.

MAIORINO, M.; GREGOLIN, C.; URSINI, F. Phospholipid hydroperoxide glutathione peroxidase. Methods in Enzymology, v.186, p.448-457, 1990.

MARIN-GUZMAN, J.; MAHAN, D. C.; CHUNG, Y. K.; PATE, J. L.; POPE, W. F. Effects of dietary selenium and vitamin $\mathrm{E}$ on boar performance and tissue responses, semen quality, and subsequent fertilization rates in mature gilts. Journal of Animal Science, v. 75, p. 29943003, 1997. 
MARIN-GUZMAN, J.; MAHAN, D. C.; PATE, J. L. Effect of dietary selenium and vitamin E on spermatogenic development in boars. Journal of Animal Science, v. 78, p. 1537-1543, 2000a.

MARIN-GUZMAN, J.; MAHAN, D. C.; WHITMOYER, R. Effect of dietary selenium and vitamin $\mathrm{E}$ on the ultrastructure and ATP concentration of boar spermatozoa, and the efficacy of added sodium selenite in extended semen on sperm motility. Journal of Animal Science, v. 78, p. 1544-1550, 2000b.

MULLAN, B., HERNANDEZ, A.; D’SOUZA, D.; PLUSKES, J. Modern pig nutrition for performance: Minerals, metabolism and the environment. In: Nutritional biotechnology in the feed and food industries PROCEEDINGS OF ALLTECH'S $22^{\text {ST }}$ ANNUAL SYMPOSIUM, Lexington, Kentucky. Proceedings... United Kingdom: Nottingham University Press, 2006. p. 22-25.

MUNIZ, I.R.S.; NEVES, J.F. Interações entre nutrição e reprodução de cachaços. Suínos \& Cia, n. 14, p. 38-45, 2005.

NAM, S.Y.; FUJISAWA, M.; KIM, J. S.; KUROHMARU, M.; HAYASHI, Y. Expression pattern of phospholipid hydroperoxide glutathione peroxidase messenger ribonucleic acid in mouse testis. Biology of Reproduction, v. 58, p. 1272-1276, 1998.

NICHI, M. Sistemas de proteção enzimática e níveis de peroxidação espontânea dos lipídios seminais de touros zebuínos e taurinos criados a campo na região de Dourados, MS. 101 p. Tese (Doutorado) - Faculdade de Medicina Veterinaria e Zootecnia, Universidade de São Paulo, Departamento de Reprodução Animal, São Paulo, 2003.

NUTRIENT REQUIREMENTS OF SWINE. $10^{\text {th }}$ revised edition. $189 \mathrm{p}$. National Academy of Sciences, Washington DC., 1998.

OLIVEIRA, G. M. Substancias reativas ao ácido tiobarbitúrico e teste hiposmótico como métodos auxiliares ao exame de motilidade retilínea e progresiva para avaliação de sêmen de touros Nelore PO, antes do congelamento. 46 p. Dissertação (Mestrado) Faculdade de Medicina Veterinária e Zootecnia, Universidade de São Paulo, Departamento de Reprodução Animal, São Paulo, 2003.

OLSON, G. E.; WINFREY, V. P.; NAGDAS, S. K.; HILL, K. E.; BURK, R. F. Selenoprotein $\mathrm{P}$ is required for mouse sperm development. Biology of Reproduction, v. 73, p. 201-211, 2005 .

OLSON, O.E.; PALMER, L.S.; CARY, E.L. Modification of the official Fluorimetric method for selenium in plants. Journal of Association of Official Analytical Chemists, v. 58, p. 117-121, 1975.

ÕURA C.; TOSHIMORI K. Ultrastructural studies on the fertilization of mammalian gametes. International Review of Cytology, v.122, p.105- 151, 1990.

PAP, E. H. W.; DRUMMEN G. C. C.; WINTER, V. J.; KOOIJ, T. W. A.; RIJKEN, P.; WIRTZ, K. W. A.; OP DEN KAMP, A. A. F.; HAGE W. J.; POST, J. A. Ratio-fluorescence microscopy of lipid oxidation in living cell using C11-BODIPY ${ }^{581 / 591}$, FEBS Letter, v. 453, p.278-282, 1999. 
PFEIFER, H.; CONRAD, M.; ROETHLEIN, D.; KYRIAKOPOULOS, A.; BRIELMEIER, M.; BORNKAMM, G.W.; BEHNE, D. Identification of a specific sperm nuclei selenoenzyme necessary for protamine thiol cross-linking during sperm maturation. FASEB Journal, v. 15, p. 1236-1238, 2001.

POWER, R; HORGAN, K. Biological chemistry and absorption of inorganic and organic trace metals. In: PROCEEDINGS OF ALLTECH'S $16^{\mathrm{TH}}$ ANNUAL SYMPOSIUM BIOTECHNOLOGY IN THE FEED INDUSTRY, 2000, United Kingdom. Proceedings... Thrumpton: Nottighan University Press, 2000. p. 277.

PUGLISI, R.; TRAMER, F.; PANFILI, E.; MICALI, F.; SANDRI, G.; BOITANI, C. Differential splicing of the phospholipid hydroperoxide glutathione peroxidase gene in diploid and haploid male germ cells in the rat. Biology of Reproduction, v. 68, p. 405-411, 2003

RAPHAEL, C.F.; ANDRADE. A.F.C.; NASCIMENTO, J.; ARRUDA, R.P.; Effects of centrifugation on membrane integrity and lipid peroxidation of equine cooled spermatozoa. In: 5th International Symposium on Stallion Reproduction, 2008. Animal Reproduction Science, v. 107, p. 344-345.

ROTRUCK, J. T.; POPE, A. L ; GANTHER, H. E.; SWANSON, A. B.; HAFEMAN, D. G.; HOEKSTRA, W. G. Selenium: Biochemical Role as a Component of Glutathione Peroxidase. Science, v. 179, n. 4073, p. 588-590, 1973.

ROVERI, A.; MAIORINO, M.; URSINI, F. Enzimatic and immunological measurements os soluble and membrane-bound phospholipid-hydroperoxide glutathione peroxidase. Methods in enzymology, v.233, p. 202-213, 1994.

SAS INSTITUTE (CARY NC), SAS User's guide: Statistical Analysis System, release 6.12 1999.

SARLÓS, P.; MOLNÁR, A.; KÓKAI, M.; GÁBOR, G.; RÁTKY, J. Comparative evaluation of the effect of antioxidants in the conservation of ram semen. Acta Veterinaria Hungarica, v. 50, n. 2, p. 235-245, 2002.

SCHRAUZER, G. N. Selenomethionine: a review of its nutritional significance, metabolism, and toxicity. Journal of Nutrition, v. 130, p. 1653-1656, 2000.

SEGERSON, E. C.; GETZ, W. R.; JOHNSON, B. H. Selenium and reproductive function in boars fed a low selenium diet. Journal of Animal Science, v. 53, n. 5, 1981.

SHALINI, S., BANSAL, M. P. Dietary selenium deficiency as well as excess supplementation induces multiple defects in mouse epididymal spermatozoa: Understanding the role of selenium in male fertility. International Journal of Andrology, v. 31, p. 438-449, 2008.

STOREY, B. T. Biochemistry of the induction and prevention of lipoperoxidative damage in human spermatozoa. Molecular Human Reproduction, v. 3, p. 203-213, 1997.

STRADAIOLI, G.; SYLLA, L.; MONACI, M.; MAIORINO, M. Phospholipid hydroperoxide glutathione peroxidase in bull spermatozoa provides a unique marker in the quest for semen quality analysis. Theriogenology, v. 72, p. 91-98, 2009. 
STUBBS, C.D.; SMITH, A.D. The modification of mammalian membrane polyunsaturated fatty acid composition in relation to membrane fluidity and function. Biochimica et Biophysica Acta, v. 779, p. 89-137, 1984.

SURAI, P. F.; KOSTJUK, I. A.; WISHART, G.; MACPHERSON, A.; SPEAKE, B.; NOBLE, R. C.; IONOV, I. A.; KUTZ, E. Effect of vitamin E and selenium of cockerel diets on glutathione peroxidase activity and lipid peroxidation susceptibility in sperm, testes and liver. Biological Trace Element Research, v. 64, p. 119-132, 1998.

THOMPSON, C.D.; STEWART, R.D.H. Metabolic studies of ${ }^{75} \mathrm{Se}$ ] selenomethionine and $\left.{ }^{75} \mathrm{Se}\right]$ selenite in the rat. British Journal of Nutrition, v. 30, p. 139-147, 1973.

TODD, S. E.; HENDRIKS, W. H. Comparative selenium metabolism in cats and dogs. In: NUTRITIONAL BIOTECHNOLOGY IN THE FEED AND FOOD INDUSTRIES PROCEEDINGS OF ALLTECH'S $21^{\text {ST }}$ ANNUAL SYMPOSIUM, 2005, United Kingdom. Proceedings... United Kingdom: Nottingham University Press, 2005. p. 389-397.

TRAMER, F.; ROCCO, F.; MICALI, F.; SANDRI, G.; PANFILI, E. Antioxidant systems in rat epididymal spermatozoa. Biology of Reproduction, v. 59, p. 753-758, 1998.

TRAMER, F.; MICALI,F.; SANDRI, G.; BERTONI, A.; LENZI, A.; GANDINI, L.; PANFILI, E. Enzymatic and immunochemical evaluation of phospholipid hydroperoxide glutathione peroxidase (PHGPx) in testes and epididymal spermatozoa of rats of different ages. International Journal of Andrology, v. 25, p. 72-83, 2002.

UNDERWOOD, E.J. The mineral nutrition of livestock. $3^{\text {a }}$ Edition. Wallingford: CABI, 1999. 614p.

URSINI, F.; MAIORINO, M.; VALENTE, M.; GREGOLIN, C. Purification from pig liver of a protein which protects lipossomes and biomembranes from peroxidative degradation and exhibits glutathione peroxidase activity on phosphatidylcholine hydroperoxides. Biochimica et Biophysica Acta, v. 710, p. 197-211, 1982.

URSINI, F.; HEIM, S.; KEISS, M.; MAIORINO, M.; ROVERI, A.; WISSING, J.; FLOHE, L. Dual function of the selenoprotein PHGPx during sperm maturation. Science, v. 277, p. 225-228, 1999.

VIEIRA, S.L. Minerais quelatados na nutrição animal. In: SIMPÓSIO SOBRE MANEJO DE AVES E SUÍNOS. CBNA - Campinas, SP, p. 51-70, 2004.

VISHWANATH, R.; SHANNON, P. Do sperm cells age? A review of the physiological changes in sperm during storage at ambient temperature. Reproduction, Fertility and Development, v. 9, p. 321-331, 1997.

VYT, P.; MAES, D.; RIJSSELAERE, T.; DEJONCKHEERE, E.; CASTRYCK, F.; VAN SOOM, A. Motility assessment of porcine spermatozoa: a comparison of methods. Reproduction in Domestic Animals, v. 39, p. 447-453, 2004.

VYT, P.; MAES, D.; SYS, S.; RIJSSELAERE, T.; VAN SOOM, A. Air contact influences $\mathrm{pH}$ of extended porcine semen. Reproduction in Domestic Animals, v. 42, p. 218-220, 2007. 
ZHENG, R.; ZHANG, H. Effects of ferulic acid on fertile and asthenozoospermic infertile human sperm motility, viability, lipid peroxidation, and cyclic nucleotides, Free Radical Biology \& Medicine, v. 22, n. 4, p. 581-586, 1997.

WABERSKI, D.; WEITZE, K. F.; GLEUMES, T.; SCHWARZ, M.; WILLMEN, T.; PETZOLDTS, R. Effect of time of insemination relative to ovulation on fertility with liquid and frozen boar semen. Theriogenology, v. 42, p. 831-840, 1994.

WEITZE, K. F.; LOTZ, J. H.; EVERWAND, A.; WILLMEN, T.; WABERSKI, D. Interaction between inseminate, uterine and ovarial function in the sow ii. Investigations into the influencing of ovulation by the use of sperm free media. Reproduction in Domestic Animals, v. 25, p. 197-204, 1990.

WEITZEL, F.; WENDEL, A. Selenoenzymes Regulate theA ctivity of Leukocyte 5Lipoxygenase via the Peroxide Tone. Journal of Biological Chemistry, v. 268, n. 9, p. 62886292, 1993.

WHANGER, P.D. \& BUTLER, J.A. Effects of various dietary levels of selenium as selenite or selenomethionine on tissue selenium levels and glutathione peroxidase activity in rats. Journal of Nutrition, s.L., v.118, p.846-852, 1988.

WU, S. H., OLDFIELD, J. E.; WHANGER, P. D.; WESWIGS, P. H. Effect of selenium, vitamin e, and antioxidants on testicular function in rats. Biology of Reproduction, v. 8, p. 625-629, 1973. 


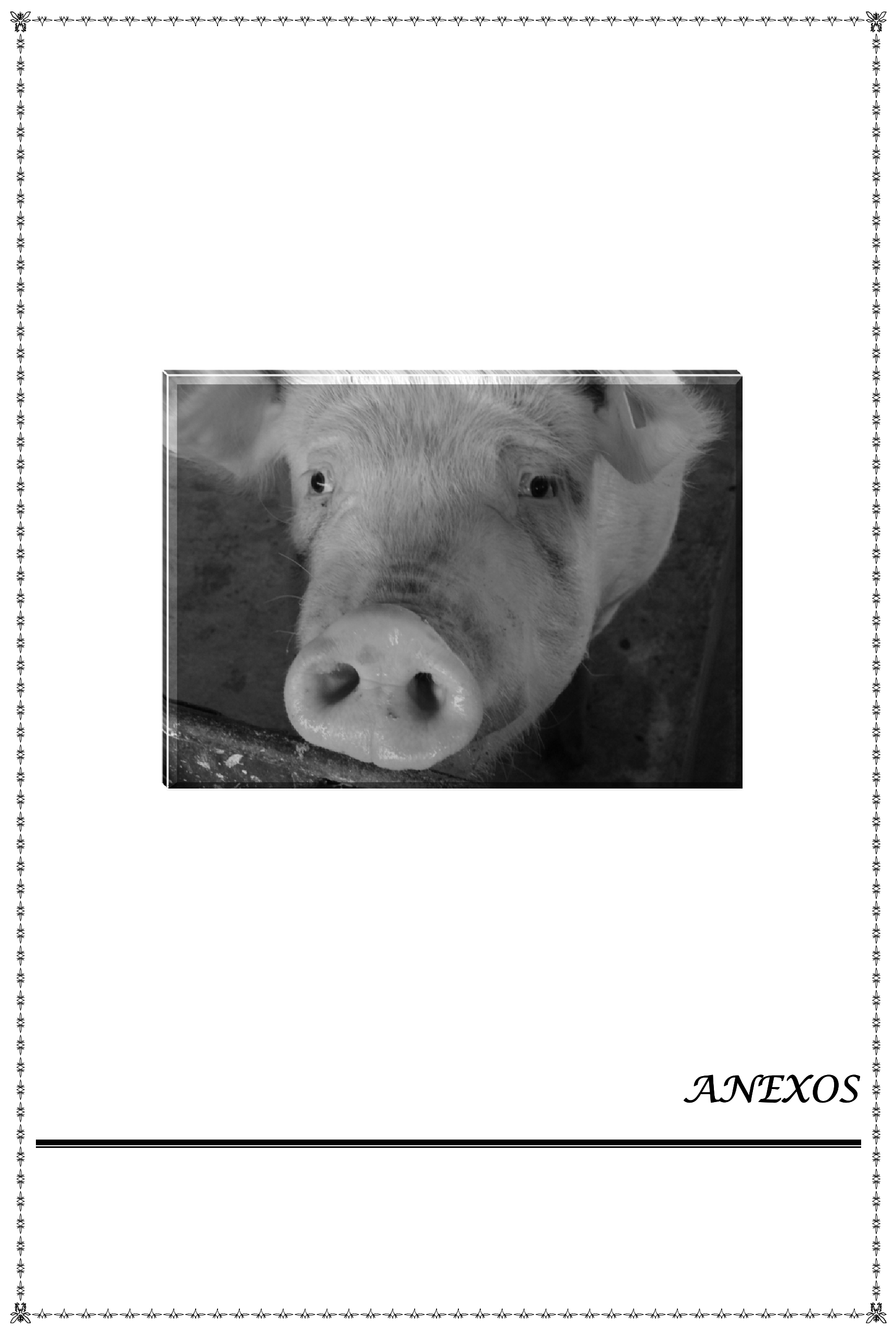




\section{ANEXOS}

\section{ANEXO A - AJUSTE DO IVOS - 12.3 PARA ANÁLISE DE SÊMEN SUÍNO}

\begin{tabular}{ll}
\hline \hline Característica & Ajuste \\
\hline Número de imagens adquiridas (Image capture: frames) & 45 \\
\hline Taxa de aquisição das imagens (Image caprure: frames per sec) & $60 \mathrm{~Hz}$ \\
\hline Contraste mínimo da célula (Cell detection: minimum contrast) & 46 pixels \\
\hline Tamanho mínimo da célula (Cell detection: minimum size) & 7 pixels \\
Tamanho para células imóveis (Defauts: cell size) & 0,32 a 1,51 \\
\hline Intensidade para células imóveis (Defauts: cell intensity) & 30 pixels \\
\hline Referência de VAP para células progressivas (Progressive cells: VAP) & $45,0 \mu \mathrm{m} / \mathrm{s}$ \\
\hline Referência de STR para células progressivas (Progressive cell: STR) & $45 \%$ \\
\hline Referência de VAP para células lentas (Slow cells: VAP Cut-off) & $5,0 \mu \mathrm{m} / \mathrm{s}$ \\
\hline Referência de VSL para células lentas (Slow cells: VSL Cut-off) & $20,0 \mu \mathrm{m} / \mathrm{s}$ \\
\hline Limite superior de tamanho da célula (Qc plots: Static size gates-Max) & $1,51 \mathrm{pixels}$ \\
\hline Limite inferior do tamanho da célula (Qc plots: Static size gates-Min) & $0,32 \mathrm{pixels}$ \\
\hline Limite superior de intensidade da célula (Qc plots: Static intensity gates-Max & 1,19 \\
\hline Limite inferior da intensidade da célula (Qc plots: Static intensity gates-Min) & 0,24 \\
\hline Limite superior de alongamento da célula (Qc plots: Cell elongation-Max) & $98 \%$ \\
\hline Limite inferior de alongamento da célula (Qc plots: Cell elongation-Min) & $0 \%$ \\
\hline Aumento (optics: Magnification) & 1,89 \\
\hline Temperatura (Stage: Set stage temperature) & $37{ }^{\circ} \mathrm{C}$ \\
\hline \hline
\end{tabular}




\section{ANEXO B - TALP SPERM MODIFICADO}

1. SOLUÇÃO DE SAIS DE TALP (para preparar $500 \mathrm{~mL}$ )

\section{Componentes:}

- $\quad \mathrm{NaC}$ $2,100 \mathrm{~g}$

- $\mathrm{KCl}$ $0,935 \mathrm{~g}$

- $\quad \mathrm{NaH}_{2} \mathrm{PO}_{4}$ $0,025 \mathrm{~g}$

- $\mathrm{MgCl} 6 \mathrm{H}_{2} \mathrm{O}$ $0,040 \mathrm{~g}$

- Hepes $3,250 \mathrm{~g}$

\section{Preparo:}

- Diluir $\mathrm{MgCl} 6 \mathrm{H}_{2} \mathrm{O}$ em $200 \mathrm{~mL}$ de água destilada

- $\quad$ Diluir outros sais em $200 \mathrm{~mL}$ de água destilada

- Combinar as duas soluções e completar para $500 \mathrm{~mL}$

- $\quad$ Manter Refrigerado

\section{SOLUÇÃO DOS METABÓLITOS GLICOSADOS}

\subsection{SOLUÇÃO ESTOQUE (PARA PREPARAR $50 \mathrm{ML}$ )}

\section{Componentes:}

- $\quad$ Glicose.............................. 2,50 g

- $\quad$ Lactato de sódio............... 9,25 mL

- $\quad$ Piruvato de sódio.............. $70 \mathrm{mg}$

- $\quad$ Pen-Strep ${ }^{\circledR}$....................... 12,5 mL

\section{Preparo:}

- Dissolver todos os componentes

- $\quad$ Aliquotar (alíquotas de $5 \mathrm{~mL})$ Manter em freezer $\left(-20^{\circ} \mathrm{C}\right)$

2.2 SOluÇÃo TRABAlHo 


\section{Preparo:}

- Colocar $45 \mathrm{~mL}$ da solução de Sais de TALPm

- Colocar $5 \mathrm{~mL}$ da solução estoque de Metabólitos Glicosados

- $\quad$ Aliquotar (alíquotas de $250 \mu \mathrm{L}$ )

- $\quad$ Ajustar $\mathrm{pH}$ para 7,4

- $\quad$ Manter em freezer $\left(-20^{\circ} \mathrm{C}\right)$

\section{TALP SPERM MODIFICADO (preparo no dia)}

\section{Componentes:}

- $10 \mathrm{~mL}$ da solução de Sais de TALPm

- $\quad 200 \mu \mathrm{L}$ da solução trabalho de Metabólitos Glicosados

\section{Preparo:}

- $\quad$ Misturar os componentes e incubar por 10 minutos

- $\quad$ Ajustar o $\mathrm{pH}$ para 7,4 


\section{ANEXO C - SOLUÇÕES PARA PHGPX}

1. PBS (X5) (para preparar 5 litros)

\section{Componentes:}

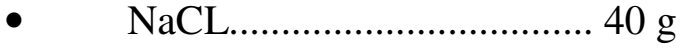

- $\quad \mathrm{KCl} \ldots \ldots \ldots \ldots \ldots \ldots \ldots \ldots \ldots \ldots \ldots . . . . . . . . . . . . . . . . .1 \mathrm{~g}$

- $\mathrm{KH}_{2} \mathrm{PO}_{4} \ldots \ldots \ldots \ldots \ldots \ldots \ldots \ldots . . . . . . . . . .6,6 \mathrm{~g}$

- $\quad \mathrm{Na}_{2} \mathrm{HPO}_{4}$ anidro $\quad \ldots \ldots \ldots . . .4,45 \mathrm{~g}$

- $\quad \mathrm{H}_{2} 0$ q.s.p. ..................... $1000 \mathrm{~mL}$

\section{Preparo:}

- $\quad$ Diluir todos os componentes em $1000 \mathrm{~mL}$ de água destilada

- $\quad$ Corrigir o $\mathrm{pH}$ para 7,4

- $\quad$ Manter Refrigerado

2. TAMPÃO DE LISE (para preparar $10 \mathrm{~mL}$, preparo no dia)

\section{Componentes:}

- $\quad$ TRIS-HCl (pH 7,5)

$8 \mathrm{~mL}$

- Guanidina-HCl

- $\quad$ Pepstatina A

- 2-Mercaptoetanol $70,8 \mu \mathrm{L}$

\section{Preparo:}

- Dissolver a guanidina-HCl em 8 mL de TRIS-HCl

- Acrescentar a pepstatina A e o 2-mercaptoetanol

- Completar o volume 
3 TAMPÃO TRIS-HCl 0,1M pH 7,5 (para preparar 100 mL)

\section{Componentes:}

- Trizma $1,211 \mathrm{~g}$

- $\quad \mathrm{H}_{2} \mathrm{O}$ Milli-Q $100 \mathrm{~mL}$

\section{Preparo:}

- Dissolver o Trizma em $80 \mathrm{~mL}$ de água Milli-Q

- $\quad$ Corrigir o $\mathrm{pH}$ para 7,5 utilizando $\mathrm{HCl}$ concentrado

- $\quad$ Completar o volume e manter refrigerado

4 TAMPÃO DE ELUIÇÃO (para preparar 100 mL)

\section{Componentes:}

- $\quad$ TRIS-HCl (pH 7,5) $80 \mathrm{~mL}$

- $\quad$ Glutationa reduzida (GSH) $0,0922 \mathrm{~g}$

- $\quad$ Ácido Etileno Diamino Tetracético (EDTA)

$0,1861 \mathrm{~g}$

- $\quad$ Triton $\mathrm{X}-100$ $100 \mu \mathrm{L}$

\section{Preparo:}

- Dissolver o GSH em 80 mL de TRIS-HCl

- $\quad$ Acrescentar o EDTA e o Triton X-100

- $\quad$ Corrigir o pH para 7,5 utilizando $\mathrm{NaOH}$

- Completar o volume e manter refrigerado 
5 TAMPÃO DE REAÇÃO (para preparar $10 \mathrm{~mL}$ )

Componentes:

- $\quad$ TRIS-HCl (pH 7,5)

$8 \mathrm{~mL}$

- $\quad$ Ácido Etileno Diamino Tetracético (EDTA) 0,9306 g

- $\quad$ Azida de sódio $\left(\mathrm{NaN}_{3}\right) \quad 0,0325 \mathrm{~g}$

\section{Preparo:}

- Dissolver o EDTA em $80 \mathrm{~mL}$ de TRIS-HCl e acrescentar a $\mathrm{NaN}_{3}$

- $\quad$ Corrigir o $\mathrm{pH}$ para 7,5 utilizando $\mathrm{HCl}$ concentrado

- Completar o volume e manter refrigerado

5.1 TAMPÃO TRIS-HCl 0,5 M pH 7,5 (para preparar $100 \mathrm{~mL}$ )

\section{Componentes:}

- Trizma $6,055 \mathrm{~g}$

- $\quad \mathrm{H}_{2} \mathrm{O}$ Milli-Q $100 \mathrm{~mL}$

\section{Preparo:}

- Dissolver o Trizma em $80 \mathrm{~mL}$ de água Milli-Q

- $\quad$ Corrigir o $\mathrm{pH}$ para 7,5 utilizando $\mathrm{HCl}$ concentrado

- Completar o volume e manter refrigerado

6. HIDROPERÓXIDO DE FOSFATIDILCOLINA (PC-OOH) (para preparar $22 \mathrm{~mL}$ )

\section{Componentes:}

- $\quad$ TRIS-HCl (pH 8,8) $21,84 \mathrm{~mL}$

- Deoxicolato de sódio. $0,0274 \mathrm{~g}$

- $\quad$ Fosfatidilcolina $48 \mu \mathrm{L}$ 
- $\quad$ Lipoxidase tipo IV $114 \mu \mathrm{L}$

- $\quad$ Coluna Sep-Pak $\mathrm{C}_{18}$

\section{Preparo:}

- Dissolver o Deoxicolato de sódio e a Fosfatidilcolina em tampão TRIS-HCl

- $\quad$ Acrescentar a Lipoxidase tipo IV e manter em agitação por 30 minutos

- $\quad$ Passar os $22 \mathrm{~mL}$ pela coluna Sep-Pak $\mathrm{C}_{18}$ e eluir em $2 \mathrm{~mL}$ de metanol

- Realizar a leitura no espectrofotômetro a $232 \mathrm{~nm}$ e calcular a concentração do PC-

$\mathrm{OOH}$

- $\quad$ Aliquotar (alíquotas de $1 \mathrm{~mL})$ e manter em freezer $\left(-20^{\circ} \mathrm{C}\right)$

6.1 TAMPÃO TRIS-HCl 0,2 M pH 8,8 (para preparar $250 \mathrm{~mL}$ )

\section{Componentes:}

- Trizma

$6,055 \mathrm{~g}$

- $\quad \mathrm{H}_{2} \mathrm{O}$ Milli-Q $250 \mathrm{~mL}$

\section{Preparo:}

- $\quad$ Dissolver o Trizma em $230 \mathrm{~mL}$ de água Milli-Q

- $\quad$ Corrigir o $\mathrm{pH}$ para 8,8 utilizando $\mathrm{HCl}$ concentrado

- Completar o volume e manter refrigerado

\subsection{EQUILIBAR A COLUNA Sep-Pak $\mathrm{C}_{18}$ E OBTENÇÃO DO PC-OOH}

\section{Componentes:}

- $\quad$ Coluna Sep-Pak $\mathrm{C}_{18}$

- $\quad \mathrm{H}_{2} \mathrm{O}$ Milli-Q …................... $14 \mathrm{~mL}$

- $\quad$ Metanol ….................... 4,1 mL 


\section{Preparo:}

- $\quad$ Passar pela coluna 2,1 mL de metanol (3 x volume da coluna)

- Lavar a coluna com 7 mL de água Milli-Q (10 x volume da coluna)

- $\quad$ Passar $22 \mathrm{~mL}$ do PC-OOH

- $\quad$ Lavar a coluna com $7 \mathrm{~mL}$ de água Milli-Q (10 x volume da coluna)

- $\quad$ Eluir o PC-OOH em 2 mL de metanol 


\section{ANEXO D - ANÁLISE ESTATÍTICA / GRAUS DE LIBERDADE}

1. Análise de variância para delineamento com 3 tratamentos e 6 tempos de amostragem

\begin{tabular}{cc}
\hline \hline Fonte de Variação & Graus de Liberdade \\
\hline Tratamento & 2 \\
Resíduo A & 9 \\
\hline Parcela & 11 \\
\hline Tempo & 5 \\
Tempo*tratamento & 10 \\
Resíduo B & 45 \\
\hline Sub-parcela & $\mathbf{7 1}$ \\
\hline \hline
\end{tabular}

2. Análise de variância para delineamento com 3 tratamentos e 4 períodos de amostragem

\begin{tabular}{cc}
\hline \hline Fonte de Variação & Graus de Liberdade \\
\hline Tratamento & 2 \\
Resíduo A & 69 \\
\hline Parcela & 71 \\
\hline Tempo & 3 \\
Tempo*tratamento & 6 \\
Resíduo B & 207 \\
\hline Sub-parcela & $\mathbf{2 8 7}$ \\
\hline \hline
\end{tabular}

